\title{
Cumulative enzyme release in liver disease
}

Citation for published version (APA):

Peltenburg, H. G. (1989). Cumulative enzyme release in liver disease. [Doctoral Thesis, Maastricht University]. Datawyse. https://doi.org/10.26481/dis.19890526hp

Document status and date:

Published: 01/01/1989

DOI:

10.26481/dis.19890526hp

Document Version:

Publisher's PDF, also known as Version of record

\section{Please check the document version of this publication:}

- A submitted manuscript is the version of the article upon submission and before peer-review. There can be important differences between the submitted version and the official published version of record.

People interested in the research are advised to contact the author for the final version of the publication, or visit the DOI to the publisher's website.

- The final author version and the galley proof are versions of the publication after peer review.

- The final published version features the final layout of the paper including the volume, issue and page numbers.

Link to publication

\footnotetext{
General rights rights.

- You may freely distribute the URL identifying the publication in the public portal. please follow below link for the End User Agreement:

www.umlib.nl/taverne-license

Take down policy

If you believe that this document breaches copyright please contact us at:

repository@maastrichtuniversity.nl

providing details and we will investigate your claim.
}

Copyright and moral rights for the publications made accessible in the public portal are retained by the authors and/or other copyright owners and it is a condition of accessing publications that users recognise and abide by the legal requirements associated with these

- Users may download and print one copy of any publication from the public portal for the purpose of private study or research.

- You may not further distribute the material or use it for any profit-making activity or commercial gain

If the publication is distributed under the terms of Article $25 \mathrm{fa}$ of the Dutch Copyright Act, indicated by the "Taverne" license above, 


\section{CUMULATIVE ENZYME RELEASE}

\section{IN LIVER DISEASE}




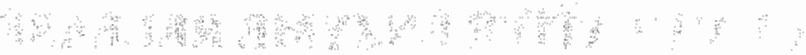

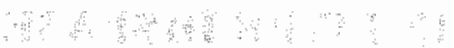




\section{CUMULATIVE ENZYME RELEASE IN LIVER DISEASE}

\section{PROEFSCHRIFT}

ter verkrijging van de graad van doctor aan de Rijksuniversiteit Limburg te Maastricht, op gezag van de Rector Magnificus, Prof. Dr. F.I.M. Bonke, volgens het besluit van het College van Dekanen, in het openbaar te verdedigen op vrijdag, 26 mei 1989 om 14.00 uur

door

Hendricus Gerardus Peltenburg geboren te 's-Gravenhage, 25 januari 1955 
Promotor "Prof. Dr. J.A. Flendrig

Co-promotor :Dr. W.Th. Hermens

Beoordelingscommissie: Prof. Dr. J.W. Arends, voorzitter

Prof, Dr. H.C. Hemker

Prof. Dr. E. Schmidt (Medizinische Hochschule Hannover)

Prof. Dr. P.B. Soeters

Prof. Dr. J.H.M. van Tongeren (Katholieke Universiteit Nijmegen)

Dr. G.M. Willems

\section{CIP-DATA KONINKLIJKE BIBLIOTHEEK, DEN HAAG}

Peltenburg, Hendricus Gerardus

Cumulative enzyme release in liver disease / Hendricus

Gerardus Peltenburg; [ill. by the author]. - Maastricht

- Dattawyse. - III.

Thesis Maastricht, - With ref. - With summary in Dutch.

ISBN 90,9002838:2

SISO 605.19 UDC 61.6.36(043.3)

Subject headings: cumulative enzyme release / liver

disease / hepatology.

Produktie: Datawyse Maastricht

Druk: Krips Repro Meppel

Dit proefschrift is mede tot stand gekomen met de financiele steun van de stichting "Het Scholten-Cordes fonds" en de "Jan Dekkerstichting \& dr. Lutgardine Bouwmanstichting". 
aan mijn vader en ter nagedachtenis aan mijn moeder 


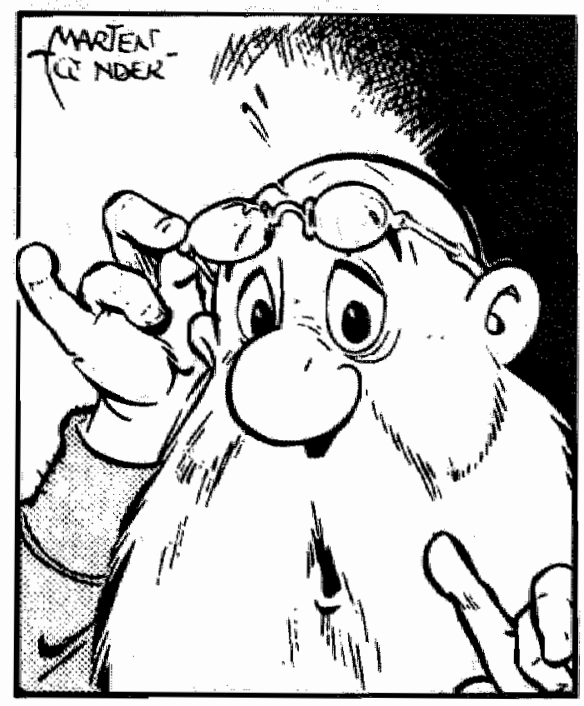

"Praw"" zo sprak hij verslagen, "als mens weet ik dat dit alles waar gebeurd is. Het heeft mij ener krachtwagen en drie hoeden gekost. Maar als wetenschapper moet ik vaststellen dat het bestaan ener droon niet is bewezen. En der kukel? Ach, we zullen nimmer weten wat der kukel is". 


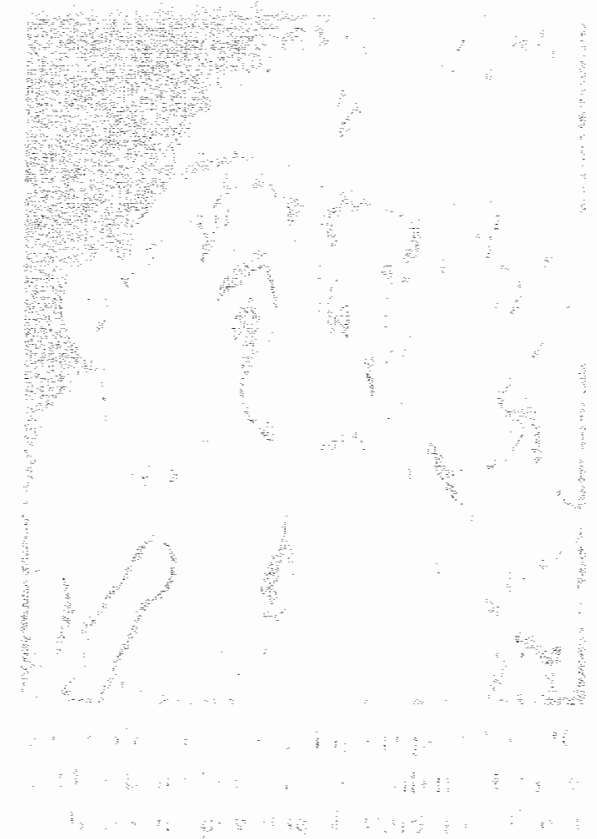

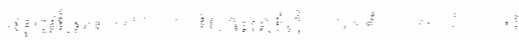

$-\quad \therefore \quad \cdots$ 


\section{CONTENTS}

Chapter 1

Introduction

Quantitative aspects of hepatic enzyme release $\ldots \ldots \ldots \ldots$

Chapter 2

Measurement of Ornithine Carbamyl Transferase (OCT) in plasma by means of enzymatic determination of ammonia . . . . . . . . 21

Chapter 3

Estimation of the Fractional Catabolic Rate constants (FCRs) for the elimination of cytosolic liver enzymes from plasma . . . . . . . . . 3

Chapter 4

Mitochondrial disruption as a primary event in acute liver necrosis . . . . 47

Chapter 5

Cumulative enzyme release in cholestasis $\ldots \ldots \ldots 7$

Chapter 6

Cumulative rellease of liver enzymes in alcoholic liver disease $\ldots \ldots$

Chapter 7

Greater than expected alanine aminotransferase activities in plasma and in hearts of patients with acute myocardial infarction

Chapter 8

Summary $\ldots \ldots \ldots \ldots \ldots \ldots$

Samenvatting (Nederlandstalig) . . . . . . . . . . . . . . 97

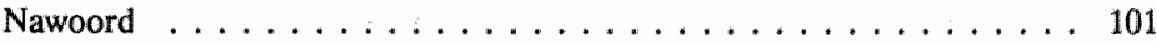

Curriculum vitae $\ldots \ldots \ldots \ldots \ldots$ 


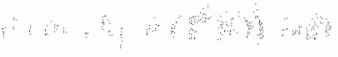




\section{Introduction}

\section{Quantitative aspects of hepatic enzyme release}

In order to relate hepatic injury to the total activity of enzyme leaked from damaged hepatocytes certain basic aspects have to be considered.

Enzyme release in plasma can only be related to the extent of damage if tissue enzyme content can be reasonably estimated, i.e. shows only a limited biological variation. Also, the physiological significance of cellular enzyme release must be understood, in particular its relation to cell death. The routes of transport of enzymes from the liver to the circulation and possible partial inactivation during this transport must be taken into account, as well as the compartments in which enzymes are distributed with the rates of exchange between these compartments and the rate of elimination of enzyme activity from plasma. These aspects determine the relevance of quantitative estimates of enzyme release and the possibility to obtain such estimates.

\section{BIOLOGICAL VARIABILITY IN TISSUE ENZYME CONTENT}

In a large review concerning liver enzyme content [1], data of various authors are compared. As a consequence of different choices of expressing measured enzyme activity, e.g. related to wet weight of tissue, tissue protein content, total DNA content, tyrosine content, nitrogen, etc., comparison of data is cumbersome. More important than these diverging ways of expressing activity are differences in variability.

Standardization and improvement of biological assays has significantly decreased variability [2]. Another source of erroneously high variability is intracellular compartmentation. If subcellular fragments are not properly disrupted by means of sonication and/or use of detergents, the content of subcellular compartments will be liberated incompletely and to a variable degree, resulting in increased scatter (cf. [3] for a comparison of different procedures).

Use of small samples $(<50 \mathrm{mg}$ ) will result in increased variability due to structural inhomogeneities (connective tissue, vessel wall). U'se of needle biopsy specimens introduces an error of about 5-10\% [4]. Data on specimens obtained from autopsy should be critically analyzed because different autolysis times may introduce variability [5]. By and large, if all these factors are considered, experimental error introduced by sample 


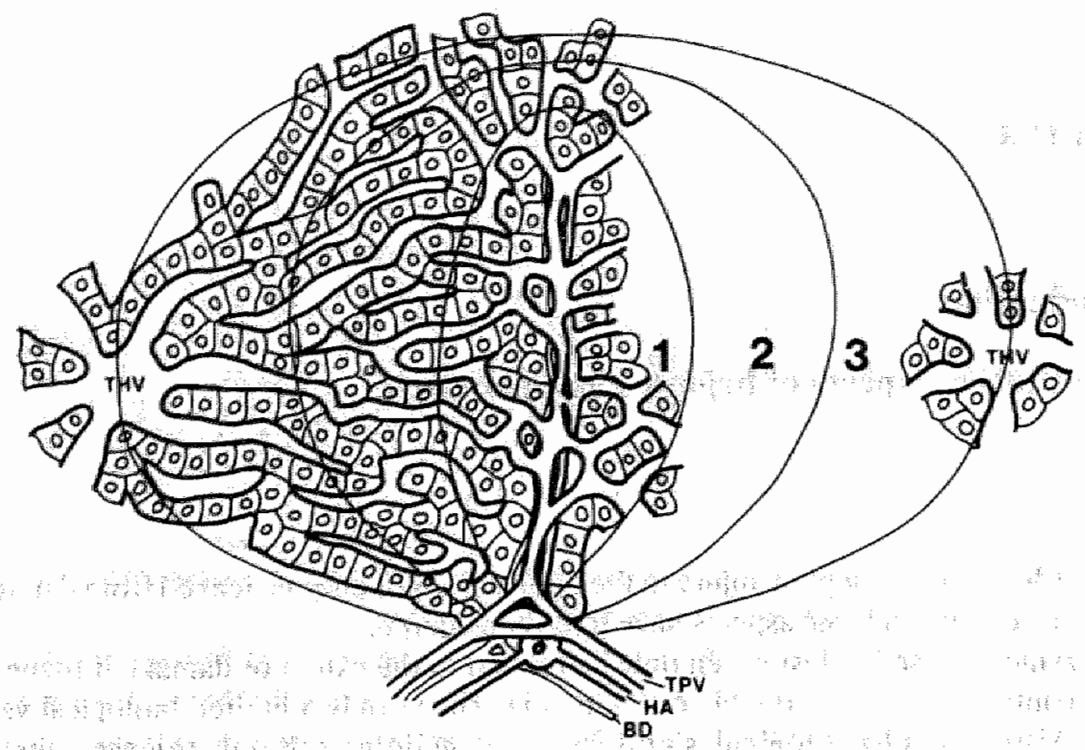

Figure LA. The hepatic acinus, the microvaseular unit of liver parenchyma:

The acinar axis is formed by the terminal branches of the portal venule (TPV), the hepatic arteriole (HA) and the bile ductule (BD). Blood enters the acinar sinusoids in zone 1 and flows sequentially through zone 2 and into acinar zone 3 , where it leaves the acinus via the terminal hepatic venule (THV). The sinusoids of zone 1 are highly anastomotic while those of zone 3 are straight and empty into the THV in a radial arrangement.

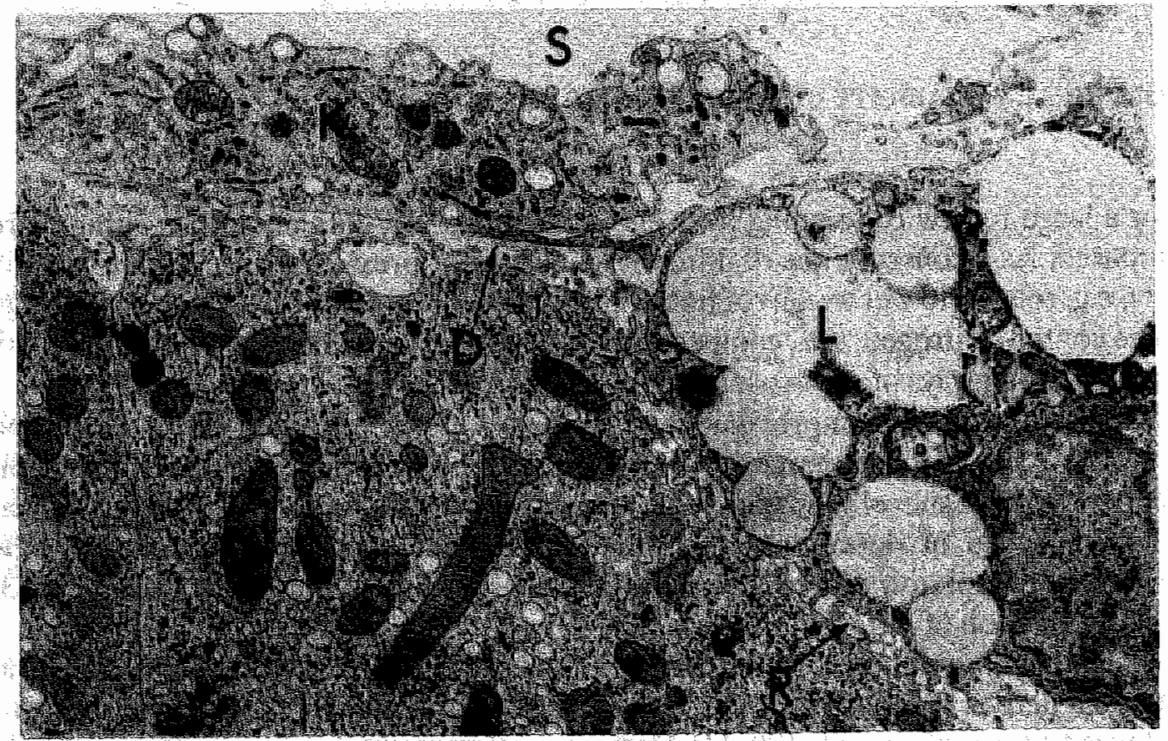

Figure 1B. Normal human liver. A portion of two hepatocytes, a Kupffer cell (K), processes of an endothelial cell, and a lipocyte (L) or Ito cell bordering a sinusoid (S) are shown. The space of Disse (D), and the perisinusoidal recess $(\mathbb{R})$ are indicated with arrows. 
manipulation and enzyme determination may account for a variability of about 10-15\% [41]. This implies that pathological changes in liver tissue in the order of $20 \%$ or more can be detected without introducing errors exceeding this magnitude.

Data on cumulative enzyme release should be interpreted with care if the organ was attacked preferentially in zones with a somewhat different enzyme content. For the liver, this complication was illustrated by the preferential damage of the perivenular zone in right-side heart failure [6].

The liver consists of about $60 \%$ parenchymal cells (about 80 volume\%), 35\% Kupffer-cells and blood vessel endothelium (about 17 volume \%). The remaining fraction consists of bile ductules and connective tissue [7]:

Differences in periportal and perivenular enzyme activities are related to differences in metabolic functions (cf. Figure 1-top) [8].

\section{Relation between enzyme release and cell death}

Ever since the original demonstration of elevated amylase activities in pancreatitis by Wohlgemut in 1908 [9], the physiological significance of cellular enzyme leakage has been debated. Some authors have argued that the permeability of the plasma membrane to macromolecules must result in irreversible damage and cell death. Others have favored the concept of enzyme leakage from reversibly injured, still viable cells. Conflicting experimental results, supporting one of these hypotheses, have been reported. Recently it has been shown in cultured and isolated cells that metabolic stress may result in a process of cell surface blebbing' by which the cell may loose part of its membrane and contents without immediate cell death $[10,11]$. This process probably also occurs in vivo but its quantitative importance remains uncertain, because only a small fraction of the total cell content is usually lost in this way and the 'blebs' consist of closed phospholipid vesicles that may retain their enzymatic contents. For the liver, with its high regenerative capacity, it has been mentioned that this debate is partiy irrelevant. In clinical practice, accumulated evidence has resulted in organ-dependent interpretation of enzyme release. For the heart, without regenerative capacity, it is generally assumed that enzyme release indicates necrosis [12], whereas hepatic enzyme release, especially the release of cytosolic enzymes without simultaneous mitochondrial enzyme leakage, is regarded as indicating reversible injury $[11,13,14]$

Possible changes in released enzyme activity, secondary to a dislocation from a highly structured cellular environment in which substrate affinity and catalytic efficiency probably differ considerably from bulk solutions, seem likely (Sofort-effekt [15]). However, for the purpose of interpretation of cumulative enzyme data in terms of gram-equivalents of tissue, these effects need not be complicating. After homogenization and sonication of tissue samples the liberated enzyme activity is measured in a plasma solution. Consequently, tissue enzyme activities can be directly compared to plasma enzyme activities. Of course, in vivo release could be quite different from liberation by homogenization and sonication. However, an effect of experimental 
manipulation on the values of $v_{\max }$ and $\mathrm{k}_{\mathrm{m}}$ has never been demonstrated, which is in agreement with the two-state hypothesis of enzyme denaturation. enzymes either retain normal activity or are completely inactivated [16].

\section{TRANSPORT OF ENZYMES FROM LIVER TO PLASMA}

In the resting individual the liver receives $25 \%$ of cardiac output even though it constitutes only $2.5 \%$ of body weight and the liver cell is richly perfused on two sides of the cell (Figure 1B). About one third of total liver blood flow is supplied by the hepatic artery and about two-thirds by the portal vein. The high-pressured oxygen-rich arterial blood mixes with the low-pressured, nutrient-rich portal venous blood in the hepatic sinusoids (Figure 1A).

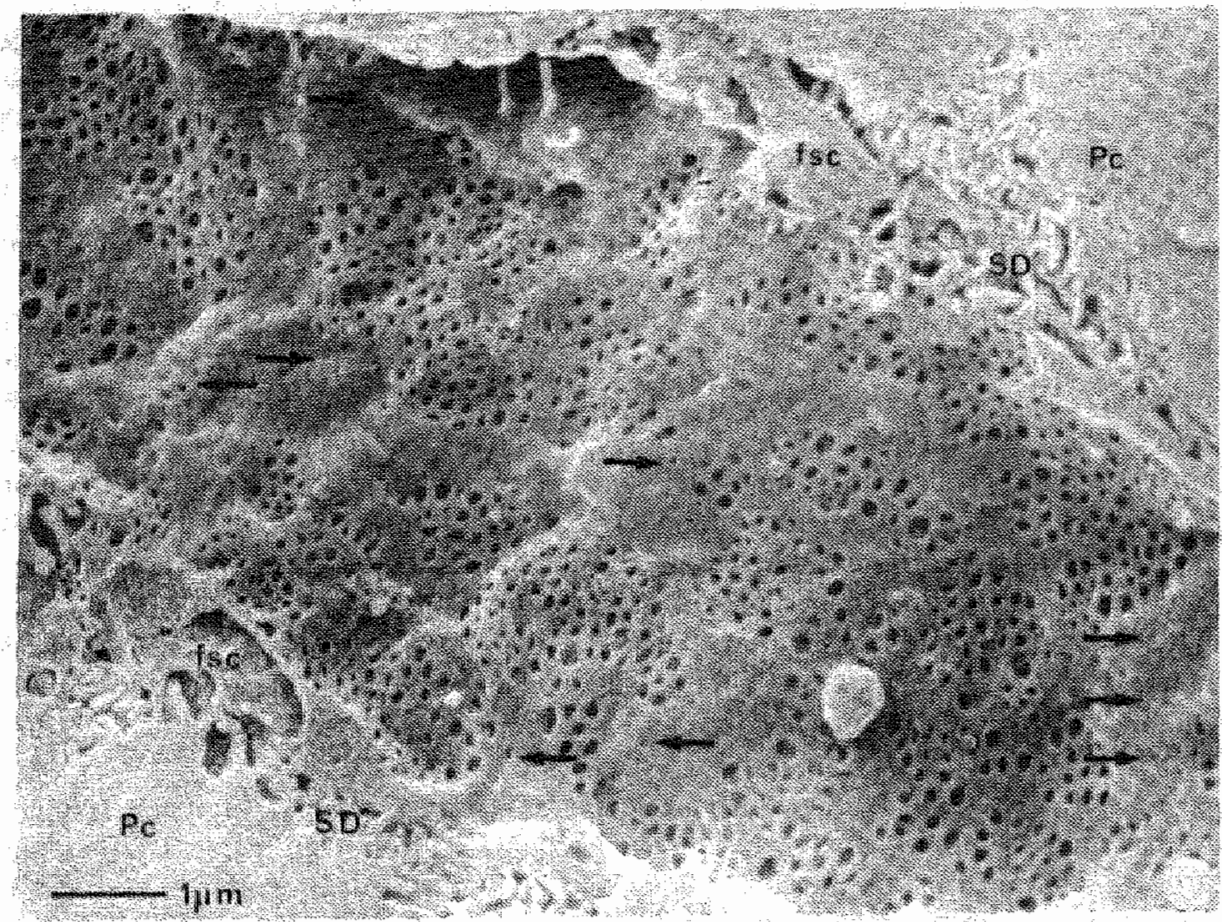

Figure 2. High power SEM miorograph depicting the size differences and clustering of fenestrae in sieve plates. Sieve plates are separated by cytoplasmic arins of endothe lial cells, in which depressions of bristlecoated micropinocytotic wesicles (coated pits) can be observed (arrows), In the space of Disse (SD) processes of fat-storing cells (FSC) can be seen. Pc. parenchymal cell with numerous microvilli protruding into the space of Disse. (From: Wisse at al. The Liver Sieve. Hepatology 1985;5:683-692) 


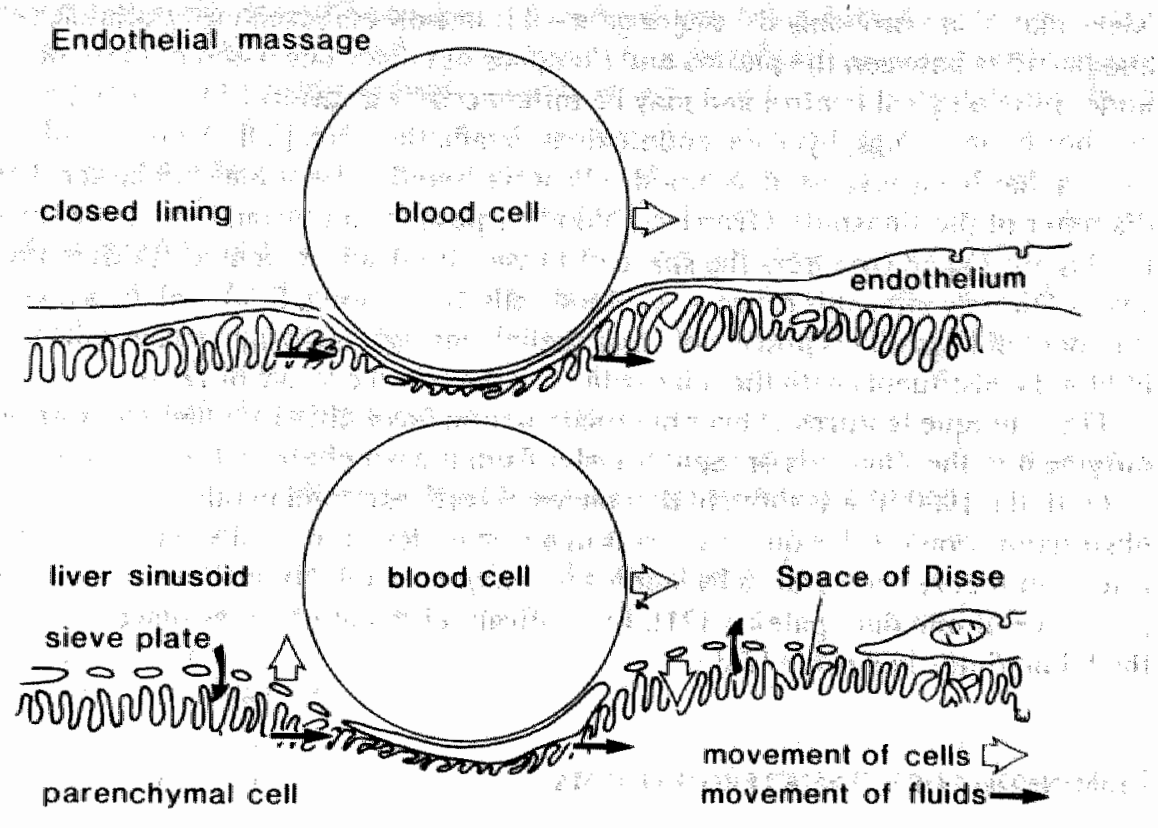

Figure 3. Diagram of the concept of endothelial massage. One of the effects of compression of the space of Disse by moving white blood cells will be displacement of fluids within this space in a downstream direction. When fenestrae are encountered, fluid will flow out of the space and when white blood cells move along, the microvilli and the endothelial lining will come back into position, and as a result fresh plasma will be sucked into the Disse's space.

After disruption of the liver cell membrane, enzymes enter the space of Disse. The fraction that escapes to the bile canaliculus is negligible. From the space of Disse the enzyme is either transported to the sinusoid or to the lymphatics. The origin of liver lymph is disputed, but most physiologists consider lymphatics in the liver as draining the space of Disse. The total protein concentration of liver lymph under resting conditions is slightly lower than plasma (about $6 \%$ ). At normal venous pressure, the lymphto-plasma concentration ratios of various protein fractions indicate significant selectivity by the blood-lymph barrier to macromolecules based on molecular size. For enzymes with an average molecular weight $M=100,000-200,000$, about half would be transported to the liver lymph [17]. Lymph flow in the liver is high [18] and therefore enzymes transported by the lympatic pathway will be rapidly transported to plasma. Some liver lymph may enter the abdominal cavity, and this quantity increases when pressure in the portal vein is elevated. The abdominal cavity is separated from the circulation by the barrier of the mesothelial membrane. Labeled proteins injected in the peritoneal cavity of the dog were rapidly absorbed (half-life of 6 hours) [19]. The liver sinusoids lack a basal membrane and have an endothelial lining consisting of cells with flattened surfaces perforated by small fenestrae of $0.1 \mu \mathrm{m}$ in size (cf. Figure 2). These 
'sieve plates' are probably the major gates of transport and exchange of fluids, solutes, and particles between the plasma and the space of Disse. The width of these pores are under physiological control and may be influenced by a variety of vasoactive substances, hormones, drugs, hypoxia, endotoxines, irradiation, etc. [20]. A process of 'forced sieving' has been suggested as blood cells were found to be somewhat larger than the diameter of the sinusoids. Oversized blood corpuscles run through the liver sinusoids (cf. Figure 3) and compress the space of Disse with displacement of fluids within this space. Directly after this process, as blood cells move along, fluids will be sucked into the space of Disse. This process of 'endothelial massage' is thought to optimize contact of blood constituents with the microvillous surface in the space of Disse.

These unique features of liver microcirculation favor either immediate transport of enzyme into the sinusoids or rapid transfer from the lymphatic pathway to the plasma.

Until the 1960s it was thought that enzymes were excreted in bile and that bile duct obstruction would subsequently result in enzyme elevation in plasma [20a]. This bile retention theory was refuted by studies on enzyme elimination that showed an independence of bile duct patency [21]. Insignificant elimination takes place by means of the biliary/intestinal route [22].

\section{ELIMINATION OF ENZYMES FROM PLASMA}

After release of enzymes from damaged cells into plasma, these enzymes are eliminated from plasma at enzyme-specific rates. Due to their high molecular weight, LDH, AST and ALT will not be cleared by the kidney, but for proteins with molecular weights below about $M=40,000$ this is usually the major pathway of elimination.

Parallel disappearance of radiolabeled enzymes and enzymatic activity have been demonstrated in several studies $[23,24]$. From these studies it is concluded that integral removal of enzymatically active molecules from the circulation takes place. In these conditions, properties of enzymes, although their physico-chernical environment has completely changed, remain unaltered.

While many organs may participate in the clearance of enzymes from plasma [25], sinusoidal liver cells play a major role in the elimination of liver enzymes by a process of adsorptive endocytosis [26]. In this receptor mediated process competition has been suggested by several studies. It was demonstrated that the plasma clearance of mitochondrial aspartate aminotransferase was significantly retarded after simultaneous injection of a high dose of mitochondrial malate dehydrogenase [27]. As extreme high amounts of enzyme were given, it is not improbable that these effects also occur in physiological or pathophysiological conditions.

Table 1 lists the various factors affecting the interpretation of quantitative enzymatic data in cell necrosis. 
Table 1. Factors affecting the relationship between cell death and enzyme release

Variability in tissue enzyme content

in biopsy (sample size)

in autopsy specimen

in analytical methods

cell heterogeneity

intracellular compartmentalization

Enzyme loss by total membrane disruption or by cell surface 'blebbing'

Factors affecting transport of enzyme into the circulation

capillary permeability

escape to the extravascular space

- lymph

- peritoneal cavity

Factors affecting enzyme elimination

local inhibition ('Soforteffekt')

urinary and intestinal excretion

receptor competition

inactivation in the extravascular space

\section{RELEVANCE OF QUANTITATIVE ESTIMATES OF ENZYME RELEASE}

As mentioned before, the first observation relating enzyme release to organ disorders dates from 1908. Although the relevance of the determination of alkaline phosphatase in bone disease was recognized around 1930 [28], it lasted until 1954, when LaDue et al. discovered the transient rise of aminotransferases after acute myocardial infarction [29], before clinical enzymology started its development to the extensive discipline of today. In $1955 \mathrm{LaDue}$ et al. also described elevated transaminases in acute hepatitis [30]. Soon after this observation, elevated plasma enzyme activities were described in many hepatic, haematological, muscular, renal and gastrointestinal diseases. 
After the initial discovery of the diagnostic value of enzyme release for the detection of organ damage, attempts have been made to correlate the amount of released enzyme activity to the extent of organ damage. In the heart, peak levels of plasma enzyme activity were correlated to histologically assessed infarction size [31]. Refinement of the methods for calculation of cumulative release, e.g. by estimating the distribution of enzyme over the extracellular compartment and by incorporation of the clearance rates of enzymes $[32,33]$, as well as improved methods for histological assessment of infarction size, have produced better correlations between enzyme release and the extent of tissue necrosis. Complete recovery in plasma of the enzyme activity lost from an organ after experimental ischemic injury has now been demonstrated for the liver [34], the kidney [35], and the heart [36]. Enzymatic quantification has become a sensitive method for the estimation of infarction size as has been demonstrated in several trials on the effect of thrombolysis in acute myocardial infarction $[37,38]$.

In the liver with its large regenerative capacity the issue of enzymatic quantification is not appealing, in contrast to the heart where necrotic cells are not replaced and cumulative enzyme release thus reflects irreversible loss of organ function. However, by comparison of the cumulative release of various liver enzymes in plasma and their activities in liver tissue, conclusions may be drawn concerning enzyme induction and enzyme depletion. It is remarkable that in the extensive literature on liver disease hardly any study is found which estimates the daily (equivalent) injury of liver tissue, for instance in the alcoholic. Figures on daily tissue loss will be interesting in view of the regenerative capacity of the liver: does replenishment of liver enzyme reflect increased protein synthesis in diseased cells or complete replacement of destructed hepatocytes?

In the myocardium ischemia is the virtually single cause of acute cell damage. The liver, however, is subject to various forms of acute cell injury (cf: Table 2).

In all these disease states cumulative release of liver enzymes from different subcellular compartments may be compared and used to answer a number of questions, such as: What is the relation between cytosolic and mitochondrial enzyme loss in these diseased states? Is there a delay between the release of cytosolic and mitochondrial enzymes? Are the losses of cytosolic and membrane-bound enzymes correlated if there is concomitant cholestatic liver injury? etc.

Table 2. Various forms of acute liver injury.

ischemic (e.g. temporary circulatory arrest)

inflammatory (e.g. viral)

drug-induced (e.g, acetaminophen)

toxic (e.g. $\mathrm{CCl}_{4}$, alcohol)

cholestatic (e.g the detergent action of bile acids)

pressure related (e.g. right-side heart failure) 
Assessment of cumulative enzyme release by means of quantification could yield important information on the value of specific enzymes as biological markers by comparison of liberated enzyme activities with tissue enzyme activities. Enzymes originating from the same subcellular compartment can be compared for this purpose. If a particular enzyme is released preferentially this would justify its use as a biomarker for the subcellular compartment. If not so, such data would support the view that subcellular enzyme release is an all-or-none phenomenon as a sequel of subcellular membrane disruption.

\section{CALCULATION OF CUMULATIVE RELEASE OF ENZYMES IN PLASMA}

In many studies on the elimination of liver enzymes from plasma the biphasic disappearance of enzymes has been stressed [ $21,39,40]$. An initial rapid phase is followed by a slower elimination phase. Mathematically this curve can be described as a sum of two exponential curves. Such a biphasic response curve can be best explained by the twocompartment circulatory model (cf. Figure 1-Chapter 3). Disappearanice of enzyme in the initial rapid phase is the result of the combined action of escape of activity to the extravascular compartment and catabolism with a fractional catabolic rate FCR. The second phase of slow elimination of enzyme activity is the result of return of activity from the extravascular compartment back to plasma in addition to the catabolic action [41].

The parameters determining the exchange of activity over the intravascular and extravascular compartments are important factors that have to be known before calculation of cumulative release will be possible. In addition, the parameter values of FCR of liver enzymes will have to be calculated.

The exchange parameters, Transcapillary Escape Rate (TER) and Extravascular Return Rate (ERR), have been estimated and these values have been confirmed in the studies on estimation of infarct size [42].

The second mentioned problem, the estimation of the parameter values of FCR of the clinically relevant liver enzymes, is a central issue in this thesis. As will be pointed out in the forthcoming chapters the selection of patients is of primary importance.

Unlike the well-defined, short-lasting type of injury characterizing acute myocardial infarction, liver damage is often ill-defined with respect to time of onset, duration and type of injury. For the purpose of estimating disappearance parameters, ongoing release of enzyme activity invalidates the estimation procedure, although some tailing release is allowed.

\section{ENZYME RATIOS}

The composition of a mixture of enzymes or isoenzymes may alter after its entry into plasma because of different removal rates for the various components. These factors 
should be carefully considered before a proportion of enzymes or profile of enzymes is regarded as indicative of a disease in a particular organ [43]. Many of the classical enzyme ratios (e.g. the de Ritis quotient [44]) probably do not reflect actual proportions of tissue enzyme release, but are distorted by the time course of release because of enzyme-specific removal rates of activity from plasma.

Provided known values of FCR of liver enzymes and the exchange parameters, it will be possible to compare actual plasma enzyme activities at time $t$ to the cumulative release of enzyme up to time $t$. By this comparison it may be possible to decide whether altered enzyme ratios reflect different time courses or actual tissue enzyme activity changes.

This line of thought can also be reversed: if the release of a certain enzyme is presupposed to occur as the result of damage to a target organ, the necessarily concomitant output of another enzyme from the same cellular compartment should be observed. This property of the simultaneity of enzyme release has been elaborated in a subset of patients with acute myocardial infarction and elevated plasma ALT levels. Such increase in ALT is classically thought to be the result of some degree of liver injury secondary to right-side heart failure. The lack of concomitant (extra) AST release in these patients, however, suggests another source of ALT in these patients.

\section{ENZYMES USED IN THE PRESENT STUDY}

This paragraph presents information on the enzymes that are investigated in the next chapters. The information includes localization of enzyme, physicochemical properties, test principles, storage features, sources of error and elimination rates from plasma.

\section{ASPARTATE AMINOTRANSFERASE}

Aspartate aminotransferase (AST; EC 2.6.1.1.) is a dimeric enzyme with a molecular weight of about $\mathrm{M}=90,000$ [45]. It requires pyridoxal-5' -phosphate for optimal action. This prosthetic group mediates amino group transfer by virtue of its easy formation of pyridoxamine derivates with amino acids: Aspartate aminotransferase reversibly catalyzes the transfer of an amino group from aspartate or glutamate to 2oxoglutarate or oxaloacetate:

AST

asparate $+\alpha$-ketoglutarate - oxaloacetate + glutamate

Two isoforms are known in vertebrates, one (cationic) mitochondrial isoenzyme (mAST) and the anionic form that originates from the cytoplasm (cAST). Isoenzymes may be separated by means of gelelectrophoresis, isoelectric focusing, immuno-inhibition and anion-cation-exchange chromatography (cf. [46] for a review). Mitochondrial 
aspartate aminotransferase is located in the intermembrane space and also bound to the inner membrane [47]. The mitochondrial isoenzyme is somewhat larger than the cytoplasmic $(M=120,000)$. Both isoenzymes are homogenously distributed over the liver lobule [1]. At $+4^{\circ} \mathrm{C}$. the activity decreases by about $15 \%$ in 24 hours. At room temperature inactivation is $20 \%$ in 24 hours [1].

In this thesis the spectrophotometric method is used for the assay of aspartate aminotransferase. After its production oxaloacetate is converted by malate dehydrogenase $(\mathrm{MDH})$ that serves as the indicator enzyme. Oxidation of NADH is measured by a decrease in absorbance at $340 \mathrm{~nm}$.

$$
\text { oxaloacetate }+\mathrm{NADH}+\mathrm{MDH}+\underset{\text { malate }}{+\mathrm{NAD}}+
$$

As a rule, estimation of enzyme activity should be carried out in the presence of supplemental pyridoxal-5'-phosphate in patients with liver disease, as a deficiency of this vitamin is a frequent finding in these patients. Increased activity of alkaline phosphatase can also contribute to this condition as this enzyme is capable of hydrolyzing pyridoxal-5'-phosphate in plasma.

The half-life time of cAST in plasma was estimated to be about 17 hours, corresponding to an apparent fractional disappearance constant $\mathrm{k}_{\mathrm{d}}=0.04 \mathrm{~h}^{-1}$ [48]. Much faster elimination of mAST as compared to cAST has been demonstrated in various species $[34,48,49]$.

\section{ALANINE AMINOTRANSFERASE}

Alanine aminotransferase (ALT; EC 2.6.1.2) is the more liver-specific aminotransferase. Its activity is relatively higher in the acinar zone I (Figure 1) by a factor 2.8 [8]. Its molecular weight is about $M=110,000$ and it contains two pyridoxal-5'phosphate groups per mole. The presence of the pyridoxal-5'-phosphate group is indispensable for optimal action of the aminotransferase (cf. AST). The enzyme reversibly catalyzes the transfer of an amino group from alanine to form glutamate and pyruvate:

ALT

alanine $+\alpha$-ketoglutarate $\Leftrightarrow$ glutamate + pyruvate

Enzyme activity is assayed spectrophotometrically at $340 \mathrm{~nm}$ with LDH as the indicator enzyme, converting pyruvate to lactate, under oxidation of $\mathrm{NADH}$ :

LDH

pyruvate $+\mathrm{NADH}+\mathrm{H}+\Leftrightarrow$ lactate $+\mathrm{NAD}+$

A mitochondrial isoenzyme has been described in rat liver, but this enzyme is very labile and represents only about $10 \%$ of total ALT activity [50]. In vitro ALT is rela- 
tively unstable, with an inactivation in 24 hours by $15 \%$ at room temperature. In contrast, the enzyme is eliminated very slowly from plasma in man with a value of $k_{d}=$ $0.029 \mathrm{~h}^{-1}[51]$.

A possible source of error in the enzyme assay of aminotransferases is the abundant presence of glutamate dehydrogenase. NADH may then be consumed not only by the transaminase-LDH/MDH-system, but also by this dehydrogenase, resulting in spuriously high values [52].

\section{LACTATE DEHYDROGENASE}

Lactate dehydrogenase ( $\mathrm{LDH} ; \mathrm{EC} \mathrm{1.1.1.27)} \mathrm{is} \mathrm{a} \mathrm{tetrameric} \mathrm{cytosolic} \mathrm{enzyme,} \mathrm{almost}$ ubiquitously distributed in animal cells. It has a molecular weight of $M=135,000$ and there are five well-known isoforms of the enzyme. It is a zinc-containing enzyme that reversibly oxidates lactate to pyruvate:

$$
\text { lactate }+\mathrm{NAD}^{+} \Leftrightarrow \text { pyruwate }+\mathrm{NADH}+\mathrm{H}^{+}
$$

Enzyme activity is assayed spectrophotometrically, by decrease in absorbance at 340 $\mathrm{nm}$. For 2-oxobutyrate used as the substrate instead of pyruvate, the affinity of LDH1 is much higher than for LDH5. This forms the basis of the HBDH-test, that allows discrimination between LDH1 and LDH5 [53]. A high HBDH/LDH ratio indicates LDH1 as the predominant isoform; a low HBDH/LDH ratio indicates LDH5. In the liver the predominant isoenzyme is LDH5, that forms $85 \%$ of total activity. Within the liver lobule the highest concentrations are found in zone I (Figure 1) [8]. The isoenzyme LDH5 is relatively unstable: storage at $-20^{\circ} \mathrm{C}$ may diminish its activity by about $20 \%$ [1].

The half-life time for the disappearance from plasma of LDH5 is estimated at 10 hours, corresponding to an apparent disappearance constant $k_{d}=0.07 \mathrm{~h}^{-1}$ [48]. The half-life time of LDH1 is estimated in the same study at 113 hours, corresponding to a value for $\mathrm{kd}_{\mathrm{d}}$ of $0.006 \mathrm{~h}^{-1}$. It is obvious from this figures that overestimation of cumulative release of LDH5 may result from persisting LDH1 levels. This is the reason why plasma was checked for LDH isoforms in the study on LDH5 elimination.

\section{GLUTAMATE DEHYDROGENASE}

Glutamate dehydrogenase (GLDH; EC 1.4.1.3) is an exclusively mitochondrial enzyme. This enzyme is a polymer with identical subunits of $M=49,000$ [54]. The lowest molecular weight measured was $M=250,000$. There are polymers with unusually high molecular weights exceeding $M=1,000,000$ and there are six isoforms. The liver uniquely contains a cathodic isoenzyme. It catalyses oxidative deamination of amino acids: 


\section{GLDH \\ glutamate + $\mathrm{NAD}^{+}+\mathrm{H} 2 \mathrm{O}-\alpha^{-0 x o g l u t a r a t e}+\mathrm{NH}_{4}++\mathrm{NADH}$}

Increase in $\mathrm{NAD}^{+}$in the reverse reaction is measured spectrophotometrically as the increase in absorbance at $340 \mathrm{~nm}$. Ghutamate dehydrogenase is a stable enzyme between $-38^{\circ} \mathrm{C}$ and $+25^{\circ} \mathrm{C}$.

The isoenzyme assay is not used for clinical diagnosis. Its activity is relatively higher in zone III of the liver acinus by a factor 17 (Figure 1) [6]. The half-life time in plasma of the enzyme is estimated at 16 hours, the corresponding $\mathrm{k}_{\mathrm{d}}=0.043 \mathrm{~h}^{-1}[55]$. An inhibitor of this enzyme has been demonstrated in Reye's disease [56].

\section{ORNITHINE CARBAMYL TRANSFERASE}

Ornithine carbamyl transferase (OCT; EC 2.1.3.3) is an exclusively mitochondrial enzyme: It is a trimer of identical $M=38,000$ subunits [57]. A precursor form is present in the cytoplasma, but there are no isoenzymes. The enzyme is present almost exclusively in liver. It plays a key role in ammonia metabolism, where it catalyzes the production of citrulline from ornithine:

OCT

ornithine + carbamyll phosphate $\Leftrightarrow$ citrulline + phosphate

The enzyme is a mitochondrial matrix enzyme, loosely attached to the inner membrane [58]. It is quite stable over a temperature range from $-50^{\circ} \mathrm{C}$ to $+60^{\circ} \mathrm{C}$ and over a $\mathrm{pH}$ range from 5.8 to 8.2 [57]. Although its liver-specificity would make it an important biomarker, the major drawback is the cumbersome enzyme determination, involving an urease step or a deproteinization step, both resulting in unwanted ammonia production $[59,60]$. A new method based on enzymatic determination of ammonia is described in Chapter 2.

The activity in the periportal area is higher than in the perivenular region of the liver acinus [61.]. Concerning the half-life time in plasma no data are present.

\section{ALKALINE PHOSPHATASE}

Alkaline phosphatases (AP; EC 3.1.3.1) are a group of non-specific enzymes which hydrolyse a variety of ester orthophosphates under alkaline conditions.

AP

R-phosphate $+\mathrm{H}_{2} \mathrm{O} \Leftrightarrow \mathrm{R} . \mathrm{OH}+\mathrm{HO}$.phosphate

In man, there are three isoenzymes: placental, intestinal and non-specific alkaline phosphatase [62], which occur in numerous allelic variants and tissue-specific multiple forms. The enzyme needs magnesium and zinc for optimal catalytic action. In the liver 
the enzyme is predominantly bound to distinct parts of the plasma membrane, but there is evidence that there is a cytosolic subfraction [63]. The molecular weight is estimated at $\mathrm{M}=120,000$ [64]. A high molecular weight form of alkaline phosphatase has been observed in plasma of patients with cholestasis, probably in association with vesicles formed by the detergent action of bile acids [65]. Enzyme activity is assayed spectrophotometrically at a wavelength of $340 \mathrm{~nm}$ by the hydrolysis of $p$ nitrophenolphosphate. The liberated $p$-nitrophenol produces an intense yellow collour in alkaline solution. This reaction may underestimate the activity of intestinal alkaline phosphatase as this isoenzyme only slowly catalyses this reaction [66]. Alkaline phosphatase is relatively stable at elevated temperatures. The liver isoform is almost completely inactivated at a pH of 3.0. An apparent disappearance constant of $0.008 \mathrm{~h}^{-1}$ is reported for the disappearance from plasma after infusion of placental alkaline phosphatase in humans [21].

\section{GAMMA-GLUTAMYL TRANSEERASE}

Gamma-glutamyl transferase (GGT, EC 2.3.2.2) is bound to the cytoplasmic membrane. Enzyme activity is assayed by using a chromogenic substrate ${ }_{;}$in this study gamma-glutamyl-carboxynitroanilide, that produces a yellow colour quantitated by measuring absorbance at $405 \mathrm{~nm}$ :

\section{L- $\gamma$-glutamyl-3-carboxy-4-nitranilide + glycylglycine - \\ L-glutamylglycylglycine +5 -amino-2-nitrobenzoate}

Various isoforms are known in different organs. The lowest measured molecular weight is $M=120,000$ but high-molecular-weight aggregates are observed [67]. Gamma-glutamyl transferase catalyzes the transfer of gamma-glutamyl groups from gamma-glutamyl peptides to other peptides, to L-amino acids, and to water. The major biological significance lies in the regulation of tissue glutathione levels and amino acid transport across cell membranes [68]. In the liver, the enzyme has been demonstrated predominantly in the luminal border of the epithelial cells lining the biliary ductules [69]. Some activity has also been demonstrated within periportal liver cells [70]. The enzyme is relatively stable at temperatures between $-20^{\circ} \mathrm{C}$ and $+20^{\circ}$ for a week. The apparent disappearance rate from plasma is $k_{d}=0.01 h^{-1}$.

\section{DESIGN OF THE STUDY}

The already mentioned problem hampering the estimation of cumulative enzyme release, i.e. the unknown values of the fractional catabolic rate constants (FCRs) for the elimination of liver enzymes from plasma, will be one of the major issues of this thesis. 
The values of the exchange parameters: Transcapillary Escape Rate (TER) and the Extravascular Return Rate (ERR), have already been estimated and confirmed in studies on infarction size [42].

To avoid assays of OCT with unwanted ammonia production a method has been developed circumventing this source of error (Chapter 2).

In Chapter 3 the results of the patient selection and the estimation of FCR values of the cytosolic liver enzymes (CAST, LDH and ALT) are presented. The values of the fractional catabolic rate constants (FCRs) for the elimination of mitochondrial liver enzymes (mAST, GLDH and OCT) from plasma are estimated in Chapter 4. The much slower catabolism of the membrane-bound enzymes alkaline phosphatase (AP) and gamma-glutamyltransferase (GGT) allows application of an adapted, much simpler procedure for the estimation of FCR in Chapter 5.

If the parameter values of FCR, TER and ERR are known these values can be used to calculate cumulative enzyme release. Such estimates are divided by the average enzyme activity per gram of wet weight liver tissue, allowing a more quantitative insight in liver injury. In this way, the estimates of liver injury based on cumulative release of different enzymes must be approximately equal and this offers a criterium for the validity of the procedure.

Comparison of cumulative release up to time $t$ will allow discrimination between actual tissue enzyme activity changes due to disease, and apparent activity changes in plasma reflecting only different time courses. This comparison is made for patients with various forms of alcohollic liver disease (Chapter 6).

The different enzyme activities in various organs allow a quantitative approach to determine the origin of enzymes in plasma. In Chapter 7 the most probable source of ALT elevation in a subset of patients with myocardial disease is discussed.

\section{REFERENCES}

1. Schmidt E, Schmidt FW. Enzyme activities in human liver. Enzym biol clin $1970 ; 11: 67-129$.

2. Schmidt E, Schmidt FW. Liver enzymology. In: Burlina A, Galzigna L, eds. Clinical Enzymology symposia. Piccin Medical Books, 1984; 7-31.

3. Schmidt E, Schmidt FW Untersuchungen über optimale Reaktions-Bedingungen für Enzym-Aktivitätsbestimmungen in Leberextrakten, in Extrakten anderer Organe und im Serum. Enzymol biol clin 1962;2:201-222.

4. McLean AEM. Leakage of enzymes from human and rat liver slices. Biochem J 1963;89:54.

5. Van der Laarse A, Dijkshoorn $\mathrm{Nj}$, Hollaar $\mathrm{L}$, Caspers $\mathrm{T}$ : The (iso)-enzyme activities of lactate dehydrogenase, alpha-hydroxybutyrate dehydrogenase, creatine kinase and aspartate aminotransferasein human myocardial biopsies and autopsies. Cin Chim Act 1980;104:381-391. 
6. Guder WG, Habicht A, Kleiszl J, Schmidt U, Wieland $O H$. The diagnostic significance of liver cell inhomogeneity: serum enzymes in patients with central liver necrosis and the distribution of glutamate dehydrogenase in normal human liver. Z Klin Chem Klin Biochem 1975;13:311-318.

7. Popper H, Schaffner F. Die Leber, Struktur und Funktion. Georg Thieme Verlag, Stuttgart, 1961.

8. Jungermann K, Katz N. Functional Hepatocellular Heterogeneity. Hepatology $1982 ; 2: 385-395$.

9. Wohlgemut J. Ueber eine neue Methode zur quantitative Bestimmung des diastatischen Ferments. Biochem Z 1908;9:1-9.

10. Frederiks WM, Marx F. Changes in the cytoplasmilc and mitochondrial enzymes in rat liver after ischemia followed by reperfusion. Exp Mol Path 1987;47:291-299.

11. Piper HM, Hütter JF, Spieckermann PG. Relation between enzyme release and metabolic changes in reversible anoxic injury of myocardial cells. Life Sc 1984;35:127-134.

12. Hearse DJ, Humphrey SM, Chain EB. Abrupt reoxygenation of the anoxic potassium-arrested, perfused rat heart; a study of myocardial enzyme release. J Mol Cell Cardiol 1973;5:395-407.

13. Frederiks WM, Myagkaya GL, Van Veen HA, Vogels IMC, James J. The value of enzyme leakage for the prediction of necrosis in liver ischemia. Histochemistry $1983 ; 7: 459-472$.

14. Cossel L.Peripheral cytoplasmic shedding around hepatocytes- apocrine secretion, pathological cell reaction or preparation artifact? Path Res Pract 1980;170:298-327.

15. Schmidt E, Schmidt FW. Enzym-Austritt. In: Huber H. Praktische enzymologie. Bern;1968:93-148.

16. Lumry R, Biltonen R, Brandts FJ. Validity of the" two-state" hypothesis for conformational transitions of proteins. Biopolymers 1966;4:917-944.

17. Granger DN, Miller T, Allen R, Parker RE, Parker JC, Taylor AE. Permselectivity of cat liver blood-lymph barrier to endogenous macromolecules. Gastroenterology 1979;77:103-109.

18. McFarlane AS, Koj A. Short-term measurement of catabolic rates using iodinelabeled plasma proteins. J Clin Invest 1970;49:1903-1911.

19. Szabo G. Movement of proteins into blood capillaries. In: Földì M, ed. Ergebnisse der Angiologie. Basic Lymphology. Stuttgart, Schattauer FK Verlag, 1976, 31-50.

20. Wisse E, de Zanger RB, Charels K, Van der Smissen P, McCuskey RS. The liver sieve: considerations concerning the structure and function of endothelial fenestrae, the sinusoidal wall and the space of Disse. Hepatology 1985; 5:683-692.

$20^{\mathrm{a}}$. Schwarzmann V, Couinaud C, Berthaux N. Liver enzymes in biliary retention. Nature 1962;195:706-707.

21. Clubb JS, Neale FC, Posen S. The behavior of infused human placental alkaline phosphatase in hurnan subjects. J Lab Clin Med 1965;66:493-507.

22. Massarat $S$, Köbler $H$. Ueber die Elimination der cytoplasmatischen GlutamatOxalacetat-Transaminase (C-GOT) in Intestinaltrakt, Galle und Urin. Arch Klin Med 1969;216:285-302. 
23. Schapira F, Dreyfuss JC, Schapira G. La duree de sejour dans la plasma de l'aldolase chez le lapin; etude a l'aide d'une aldolase marquee a liode radioactif, $\mathrm{Rev} F \mathrm{Fr}$ Etudes Clin Biol 1962;7:829-832.

24. Massarat S. Enzyme kinetics, Half-life, and immunological properties of Iodine 131-labelled transaminases in pig blood. Nature 1965;206:508-509.

25. Bär U, Friedel R, Heine H, Mayer D, Ohlendorf S, Schmidt FW, Trautschold I. Studies on enzyme elimination. Enzyme 1973;14:133156.

26. Kamimoto $Y$, Horiuchi S, Tanase S, Morino Y. Plasma clearance of intravenously injected aspartate aminotransferase isoenzymes: evidence for preferential uptake by sinusoidal liver cells. Hepatology 1985;5:367-375.

27. Smit MJ, Wijnholds J, Duursma AM, Bouma JMW, Gruber M. Plasma clearance of mitochondrial aspartate aminotransferase in the rat: competition with mitochondrial malate dehydrogenase. Biomed Biochim Acta 1986;45:1557-1561.

28. Robison R. A new phosphoric ester produced by the action of yeast juice on hexoses. Biochem J 1922;16:809-813.

29. LaDue JS, Wroblewski F, Karmen A. Serum glutamic oxaloacetic transaminase activity in human transmural myocardial infarction. Science 1954;120:497-452.

30. Wroblewski F, LaDue JS. Serum glutamic oxaloacetic transaminase activity as an index of liver injury. A preliminary report. Ann Int Med 1955;43:345-351.

31. Agress CM, Jacobs HI, Glassner HF, Lederer MA, Clark WG, Wroblewski F, Karmen A, LaDue JS. Serum transaminase levels in experimental myocardial infarction. Circulation 1955;11:711-713.

32. Witteveen SAGJ, Hermens WTh, Hemker HC, Hollaar L. Quantitation of enzyme release from infarcted heart muscle. In: De Haas J, Hemker HC, Snellen HE; eds. Ischemic heart disease. Leiden University Press, Leiden, 1970; 36-42.

33. Witteveen SAGJ. Assessment of the extent of myocardial infarction on the basis of plasma enzyme levels. Thesis, Leiden, 1972.

34. Nishimura T, Yoshida Y, Watanabe F, Koseki M, Nishida T, Tagawa K, Kawashima Y. Blood level of mitochondrial aspartate aminotransferase as an indicator of the extent of ischemic necrosis of the rat liver. Hepatology 1986;6:701-707.

35. Maessen JG. Evaluation of ischemic injury in donor kidneys. An experimental study. (thesis), Maastricht, 1988.

36. Hermens WTh, Van der Veen FH, Willems GM, Bouman ML, Schrijvers-Van Schendel A, Reneman RS. Complete recovery in plasma of cardiac enzymes lost from infarcted tissue after permanent coronary artery occlusion in the dog. Circulation (submitted).

37. Van der Laarse A, Vermeer F, Hermens WT, Willems GM, De Neef K, Simoons ML, et al. Effects of early intracoronary streptokinase on infarct size estimated from cumulative enzyme release and enzyme release rate. A randomized trial of 533 patients with acute myocardial infarction. Am Heart J 1986;112:672-81.

38. De Zwaan C, Willems GM, Vermeer F, Res J, Verheugt FWA, Van der Laarse A, et al. Enzyme tests in the evaluation of thrombolysis in acute myocardial infaretion. Br Heart J 1988;59:175-83.

39. Klein UE, Schneider F, Sattler R. Über Eliminationshalbwertzeiten Cholestaseanzeigender Serumenzyme. Verh dtsch Ges inn Med 1975;81:1327-1329. 
40. Boyd JW. The rates of disappearance of Lactate Dehydrogenase isoenzymes from plasma. Biochim Biophys Act 1967;132:221-231.

41. Hermens WTh, Willems GM, Visser MP. Quantification of circulating proteins. The Hague: Martinus Nijhoff Publ, 1982.

42. Willems GM, Visser MP, Krill MTA, Hermens WTh. Quantitative analysis of plasma enzyme levels based upon simultaneous determination of different enzymes. Cardiovasc Res 1982; 16,120-131.

43. Posen S. Turnover of circulating enzymes. Clin Chem 1970;16:71-84.

44. De Ritis F, Coltorti M, Giusti G. An enzyme test for the diagnosis of viral hepatitis: the transaminase serum activities. Clin Chim Acta 1957; 2:70-74.

45. Kondo K, Wakabayashi S, Kagamiyama. Structural studies on aspartate aminotransferase from Escherichiae coli. J Biol Chem 1987;262:8648-8659.

46. Rej R. Aspartate aminotransferase activity and isoenzyme proportions in human liver tissue. Clin Chem 1978;24:1971-1979.

47. Gil M, Cascante M, Cortes A, Bozal J. Intramitochondrial location and some characteristics of chicken liver aspartate aminotransferase. Int J Biochem 1987;19:355-363.

48. Bar U, Ohlendorff S. Studien zur Enzymelimination. Klin Wschr 1970; 48:776-779.

49. Fleisher GA, Wakim KG. The fate of enzyme in body fluids - an experimental study. III. Disappearance rates of glutamic-oxalacetic transaminase II under various conditions. J Lab Clin Med 1963;61:98-106.

50. Ruscak M, Orlicky J, Zubor V. Isoelectric focussing of the alanine aminotransferase isoenzymes from the brain, liver and kidney. Comp Biochem Physiol 1982; 71B:141144.

51. Amelung D. Enzymelimination aus der Plasma. In: Schmidt FW, ed Praktische Enzymologie. Bern: Hans Huber, 1968:149-162.

52. Lott JA; Turner K, Garafola E. Must blanks be run for kinetic enzyme determinations? Clin Chem 1974;20:723-729.

53. Rosalki SB, Wilkinson JH. Reduction of $\alpha$-ketobutyrate by human serum. Nature $1960 ; 188: 1110-1112$.

54. Baker PJ, Farrants GW, Rice DW, Stillmanb TJ, Recent progress on the structure and function of glutamate dehydrogenase. Biochem Soc Trans 1987;15:748-751.

55. Donath $\mathbf{R}$. Die Halbwertszeit der Elimination der Serumglutamatdehydrogenase und deren Einflusz auf die Anwendung des GPT/GLDH-Quotienten für die Diagnose des akuten Verschluszikterus. Dtsch Ges wesen 1971;26:2319-2323.

56. Holt JF, Arvan DA, Mayer TK. Masking of enzyme inhibitor of raised serum glutamate dehydrogenase activity in Reye's syndrome. Lancet 1983;ii:4-7.

57. Kalousek F, Francois B, Rosenberg LE. Isolation and characterization of ornithine transcarbamylase from normal human liver. J Biol Chem 1978;253:3939-3944.

58. Powers-Lee SG, Mastico RA, Bendayan M. The interaction of rat liver carbamoyl phosphate synthetase and ornithine transcarbamoylase with inner mitochondrial membranes. J Biol Chem 1987; 262:15683-15688.

59. Kontinnen A, Simple method for the determination of ornithine transcarbamylase activity in serum. Clin Chim Acta 1967;18:147-150. 
60. Brown RW, Grisiola $\mathrm{S}$, Ornithine transcarbamylase activity in serum. J Lab Clin Med 1959;54:617-620.

61. Mizutani A. Cytochemical demonstration of ornithine carbamoyltransferase activity in liver mitochondria of rat and mouse. J Histochem Cytochem 1968;16:172180.

62. Goldstein DJ, Rogers CE, Harris H. Expression of alkaline phosphatase loci in mammalian tissues. Proc Natl Acad Sci USA 1980;77:2857-2860.

63. Simon FR, Sutherland E. Hepatic alkaline phosphatase isoenzymes: isolation, characterization and differential alteration. Enzyme 1977;22:80-90.

64. Moss DW. The heterogeneity of human alkaline phosphatase. Fed Europ Biochem Soc Sym 1970;18:227-239.

65. De Broe ME, Borgers M, Wieme RJ. The separation and characterization of liver plasma membrane fragments circulating in the blood of patients with cholestasis. Clin Chim Acta 1975;59:369372.

66. Nisselbaum JS, Schlamowtiz M, Bodansky O. Immunological studies on functionally similar enzymes Ann N Y Acad Sci 1961;94:970-982.

67. Shaw LM, London JW, Petersen. LE. Isolation of $y$-glutamyltransferase from human tiver, and comparison with the enzyme from human kidney. Clin Chem 1978;24:905-915.

68. Rosalki SB, Rau D. Serum gamma-glutamyl transferase activity in alcoholism. Clin Chim Act 1972;39:41-47.

69. Albert Z, Orlowska J, Orlowski M, Szewczuk A. Histochemical and biochemical investigations of gamma-glutamyl transpeptidase in the tissues of man and laboratory rodents. Act Histochem 1966;25:312-320.

70. Glenner GG, Folk JE, McMillan PJ. Histochemical demonstration of a gammaglutamyl transpeptidase-like activity. J Histochem Cytochem 1962;10:481-489. 


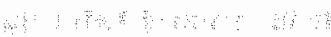

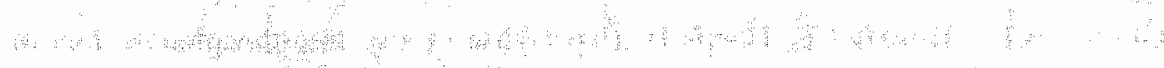

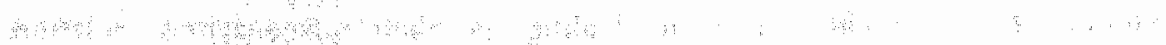

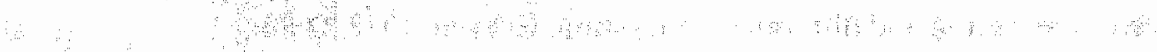
a a d a d a at $\quad$ :

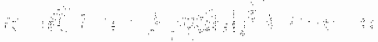


CHAPTER 2

\section{Measurement of Ornithine Carbamyl Transferase (OCT) in plasma by means of enzymatic determination of ammonia}

Henny G. Peltenburg, Mieke A. Janssen, Peter B. Soeters, J. Guus Flendrig, Wim Th. Hermens. Clinica Chimica Acta (submitted).

\section{INTRODUCTION}

Release of mitochondrial enzymes from the liver is considered as definite proof of hepatic necrosis [1,2]. Such release is also associated with specific forms of liver disease. It has been shown, for instance, that glutamate dehydrogenase (GLDH) correlated well with the presence and extent of necrosis in alcoholics [3], and the ratio of mitochondrial aspartate aminotransferase (mAST) and total aspartate aminotransferase was recently proposed as a marker of chronic alcoholism [4]. Both, GLDH and mAST, are, however, widely distributed in various organs and tissues and lack specificity as a marker of liver injury.

Ornithine Carbamyl Transferase (OCT) is located in the mitochondrial matrix of the hepatocyte and plays a role in the urea cycle.

Inherited deficiencies are described with impared ureagenesis and ammonia intoxication [5]. The enzyme was first described by Grisolia [6] and Krebs [7] and further characterized by Reichard [8]. It catalyzes the production of citrulline from ornithine by the transference of a carbamyl group from carbamyl phosphate to ornithine:

$$
\text { OCT }
$$

Ornithine + Carbamyl phosphate $\Leftrightarrow$ Citrulline $+\mathrm{P}_{1}$

Apart from some OCT activity in the small bowel mucosa, the enzyme is liver specific in man [9]. It is also a very sensitive marker of injury and plasma OCT levels may exceed normal levels by a factor of 100-1000 in various forms of liver pathology.

In view of these proportions the use of OCT as a marker of mitochondrial liver damage was advocated repeatedly but the routine use of OCT has been hampered by the complicated assay procedure. Measurement of the forward reaction by estimation of citrulline production, as proposed by Brown and Grisolia [10] and repeatedly 
modified [11], is influenced by the presence of urea which must be eliminated by a separate incubation step with urease. Reichard originally proposed measurement of the reverse reaction by addition of arsenate instead of phosphate. The carbamyl arsenate thus formed is unstable and decomposes spontaneously, producing ammonia and carbon dioxide. By using radiolabelled citrulline, the measurement of ${ }^{1 / 4} \mathrm{CO}_{2}$ provides a sensitive assay which is, however, ill-suited for routine application. Alternative measurement of ammonia was first performed with the cumbersome microdiffusion technique and the Nessler reagent. This method was simplified by direct detection of ammonia with the phenol reagent (Berthelot's reaction [12]), but both determinations require previous deproteinization of the sample and this procedure may cause elevated ammonia levels [13]. The latter author has described a method for the enzymatic determination of ammonia without the deproteinization step. This method is applied in the present study for an improved assay of OCT activity.

\section{MATERIALS AND METHODS}

The following solutions were prepared with deionized water (Millipore Q system). Unless mentioned otherwise, reagents were obtained from Sigma Chemical Co. and of analytical grade.

- Arsenate buffer (Sodium arsenate $0.5 \mathrm{~mol} / \mathrm{l}, \mathrm{pH} 7.1$ ) $7.8 \mathrm{~g}$ Sodium arsenate was dissolved in $40 \mathrm{ml}$ water, $\mathrm{pH}$ adjusted to 7.1 and the buffer was further diluted to $50 \mathrm{ml}$.

- Citrulline-arsenate buffer (L-citrulline $0.1 \mathrm{~mol} / \mathrm{l}$ ) $175 \mathrm{mg}$ L-citrulline was dissolved in $10 \mathrm{mll}$ of the sodium arsenate buffer. A fresh solution should be prepared weekly.

- Standard solutions of ammonia were prepared by dilution of a stock solution containing $330 \mathrm{mg}$ dried $\left(\mathrm{NH}_{4}\right)_{2} \mathrm{SO}_{4}$ (Merck art. 1217) in 1 liter water $(5 \mathrm{mmol} / \mathrm{l})$.

- An OCT calibration curve (cf. Figure 2) was obtained with an OCT preparation of Streptococcus faecalis, a lyophilized powder containing $40 \%$ protein and 835 Units of OCT activity per mg of protein.

\section{Incubation procedure for the OCT determination}

$-0.05 \mathrm{ml}$ plasma is addled to $0.05 \mathrm{ml}$ citrulline arsenate buffer in a microtube (Sample caps blue, Roche no. 1006789 ). A reference tube containing $0.05 \mathrm{ml}$ plasma and 0.05 $\mathrm{ml}$ arsenate buffer is used as a blank. Both tubes are firmly closed, mixed and incubated for 24 hours at $37^{\circ} \mathrm{C}$. The tubes are either directly assayed for ammonia or stored at $70{ }^{\circ} \mathrm{C}$.

\section{Ammonia assay}

- A commercially available test kit (Sigma 170-UV) was used. The assay is based on the method suggested by da Fonseca- Wollheim [13], and involves the following reaction: 


\section{GLDH \\ $\alpha-$ ketoglutarate $+\mathrm{NH}_{3}+\mathrm{NADH} \rightarrow$ glutamate $+\mathrm{NAD}^{+}$}

The disappearance of NADH is measured spectrophotometrically at a wavelength of $340 \mathrm{~nm}$.

\section{Determination of GLDH and AST activities}

- Glutamate dehydrogenase (GLDH; EC 1.2.1.3.) was assayed spectrophotometrically by means of a commercially available kit (Boehringer nr.124320).

- Total Aspartate aminotransferase (AST; EC 2.6.1.1.) activity was measured spectrophotometrically by means of a commercially available kit (Boehringer nr. B258784). Cytosolic and mitochondrial AST were separated on LD gels (Paragon, Beckman) with the method described by Sakakibara [14]. The procedure was carried out on a Beckman type P/N 65580 electrophoresis apparatus.

\section{Blood sampling}

Blood was collected in heparinized tubes kept on ice and centrifuged for $10 \mathrm{~min}$ at $1000 \mathrm{xg}$. Plasma samples were stored at $-70^{\circ} \mathrm{C}$ if the OCT determination was not performed within $30 \mathrm{~min}$ after blood collection.

\section{Patients}

Patients A,B and D were admitted to the Intensive Care ward for acute circulatory failure secondary to sepsis. Rapidly increasing liver enzyme activities indicated hepatic ischemia. Patient $\mathrm{C}$ was admitted for a biliary obstruction. By means of an endoscopic procedure the obstruction was relieved.

\section{RESULTS}

\section{Linearity}

The range of linearity of this OCT assay may either be limited by the enzymatic determination of ammonia or by the production of ammonia during the 24 hour incubation procedure. First, the capacity of the ammonia assay was tested for a series of dilutions of a standard ammonia solution ranging from 0.1 to $1.2 \mathrm{mmol} / \mathrm{l}$. Recoveries not significantly different from $100 \%$ were found in a range of ammonia concentrations up to $0.6 \mathrm{mmol} / \mathrm{l}$ (Figure 1). This figure also shows that the assay is not influenced by the presence of citrulline and arsenate in the incubation mixture. This range of ammonia concentrations corresponds to a rate of production up to $400 \mathrm{nmol}$ per minute per liter during the 24 hours incubation period, i.e. a range of OCT activity up to 400 $\mathrm{mU} / \mathrm{l}$.

The linearity of ammonia production during the 24 hours incubation period was checked with a series of dilutions of the Streptococcus preparation. As shown in Figure 2 , the production is linear to more than 5 mmoles of ammonia per 24 hours per liter, 


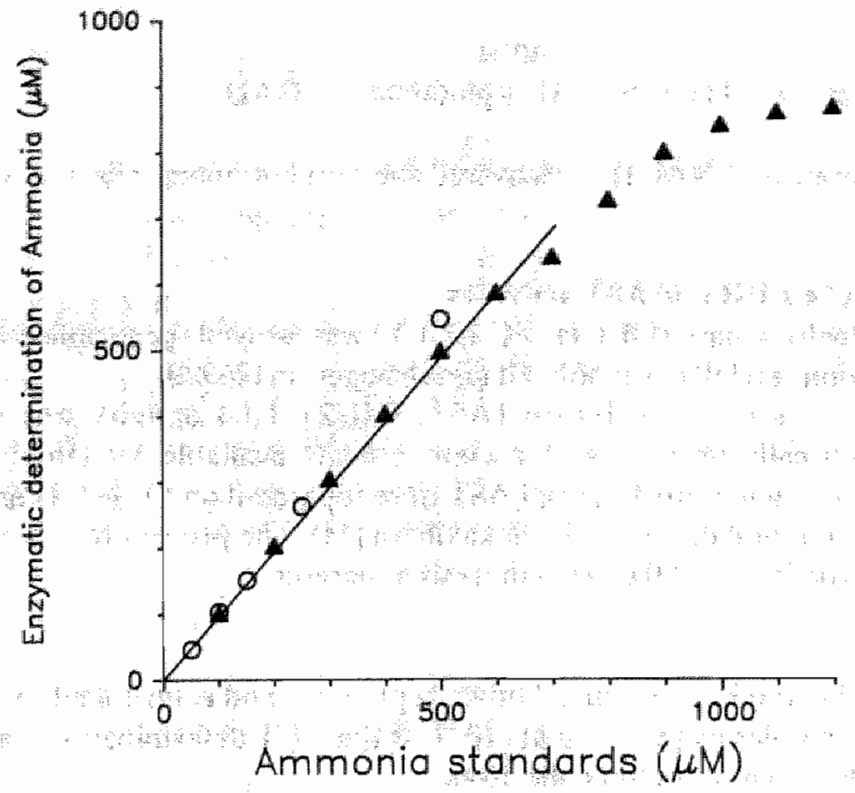

Figure 1. Limearity of the ammonia assay. Triangles indicate solutions with various ammonia concentrations; open circles indicate samples in citrulline arsenate buffer.

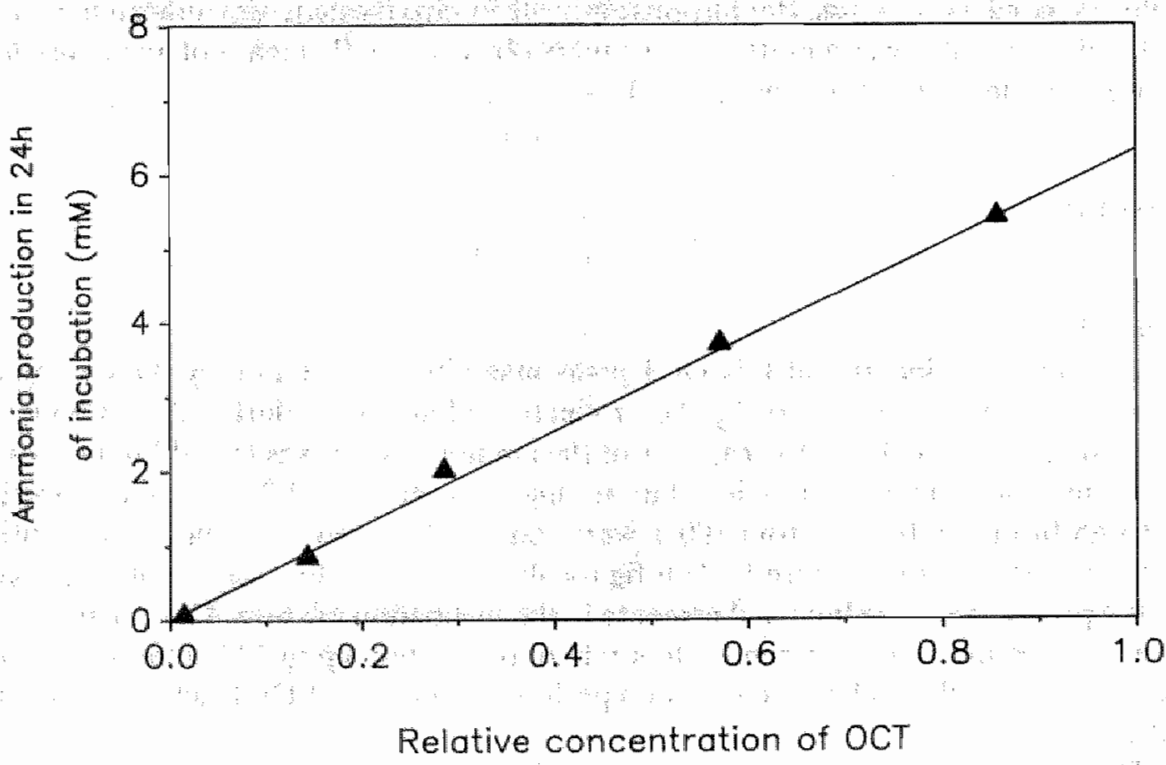

Figure 2. Figure 2 shows the linearity of the production of ammonia during the 24 hours incubation procedure. 
corresponding to an OCT activity of $3500 \mathrm{mU} / \mathrm{A}$. The concentration of citrulline in the incubation mixture hardly changes during the the production of this amount of ammonia (from 200 to $195 \mathrm{mmol} /$ ) and remains well above the value of $\mathrm{K}_{\mathrm{m}}=34 \mathrm{mmol} / \mathrm{l}$ estimated for citrulline [15]. From these data it is apparent that the linearity of the overall OCT assay is limited by the enzymatic measurement of ammonia. In order to avoid manual dilution error and to preserve a single closed vessel procedure, the use of reduced sample volumes was chosen instead of dilution. It was verified that reduction of the sample volume to $0.005 \mathrm{ml}$ did not result in a significant increase of experimental scatter. This reduction of sample volume was applied as soon as the limiting value of $400 \mathrm{mU} / \mathrm{l}$ was exceeded. Only for samples with OCT activities exceeding 4000 $\mathrm{mU} / 1$ manual dilution was applied.

\section{Precision}

Both day-to-day as within-day precision was assessed by analyzing plasma samples, liver homogenates and the Streptococcus faecalis preparation. The results are shown in Table 1.

\section{Split-sample comparison}

Plasma samples were assayed with the standard Berthelot reaction using the phenol reagent [12], and with the enzymatic method. The best fitting straight line was calculated by means of linear regression. A correlation coefficient of 0.987 was obtained with a slope of 1.01 and an intercept at the ordinate of -0.11 (Figure 3 ).

\section{Limitation of Incubation Period}

Instead of diluting samples it is also possible to shorten the period of incubation. As is shown in Figure 4 there is a linear relationship between incubation time and ammonia production. However, the error introduced by ongoing production of ammonia

Table 1. Precision of the OCT assay

\begin{tabular}{llrl}
\hline Intra assay variation & $\mathrm{n}$ & $\begin{array}{r}\text { mean } \\
(\mathrm{mU} / \mathrm{l})\end{array}$ & $\begin{array}{c}\mathrm{c.v} \\
(\%)\end{array}$ \\
\hline Normal plasma & 13 & 55 & 2.1 \\
Plasma from patients & 14 & 1188 & 2.9 \\
Liver homogenates & 16 & 10268 & 1.9 \\
\hline
\end{tabular}

\section{Interassay variation}

n $\quad \operatorname{mean}_{(\mathrm{mU} / \mathrm{h})}^{\mathrm{c.v}}$

\begin{tabular}{llrr}
\hline OCT (Str.faec.) $1: 100$ & 3 & 220 & 1.7 \\
OCT (Str.faec.) $1: 10$ & 3 & 2052 & 4.4
\end{tabular}




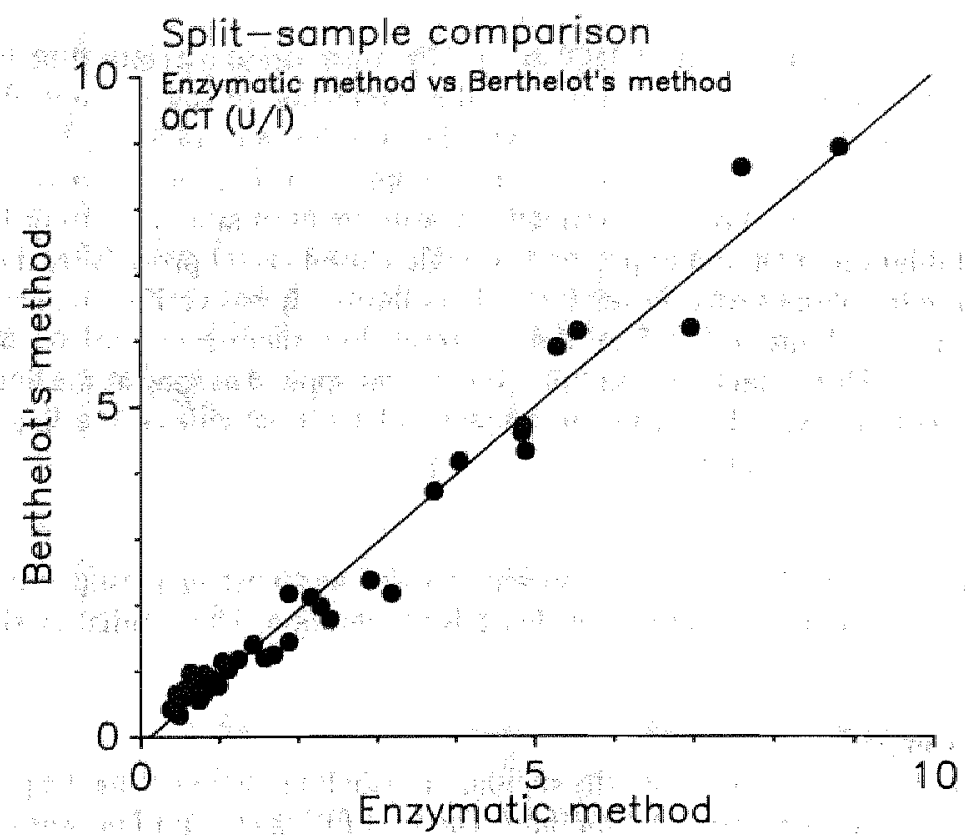

Figure 3. Comparison of the enzymatic procedure with a conventional method (Berthelot's phenol reaction).

after thawing of the plasma sample will be relatively large if incubation is limited to two hours or less. For the purpose of screening a four hour incubation period would be adequate.

\section{Simultaneous release of mitochondrial enzymes}

Figure 5 shows the mean plasma activity curves of OCT, mAST and GLDH for the four patients described in the Methods. It is apparent that the release of these mitochondrial enzymes occurs simultaneously and that OCT and GLDH are eliminated slowly from plasma especially compared to mAST.

\section{Discussion}

The properties of OCT have been studied by Kalousek et al. The enzyme is quite stable over a temperature range from $-50{ }^{\circ} \mathrm{C}$ to $+60^{\circ} \mathrm{C}$ and over a $\mathrm{pH}$ range from 5.8 to 8.2. An apparent $\mathrm{k}_{\mathrm{m}}$ for ornithine of $0.4 \mathrm{mmol} / \mathrm{l}$ and for carbamyl phosphate of 0.16 mmol/l has been estimated [15]. The value of $k_{m}$ for citrulline in the reverse reaction is $34 \mathrm{mmol} / \mathrm{l}$ for the arsenate system [16]. The maximal catalytic rate for the reverse reaction is about ten times lower than for the forward reaction [17]. 


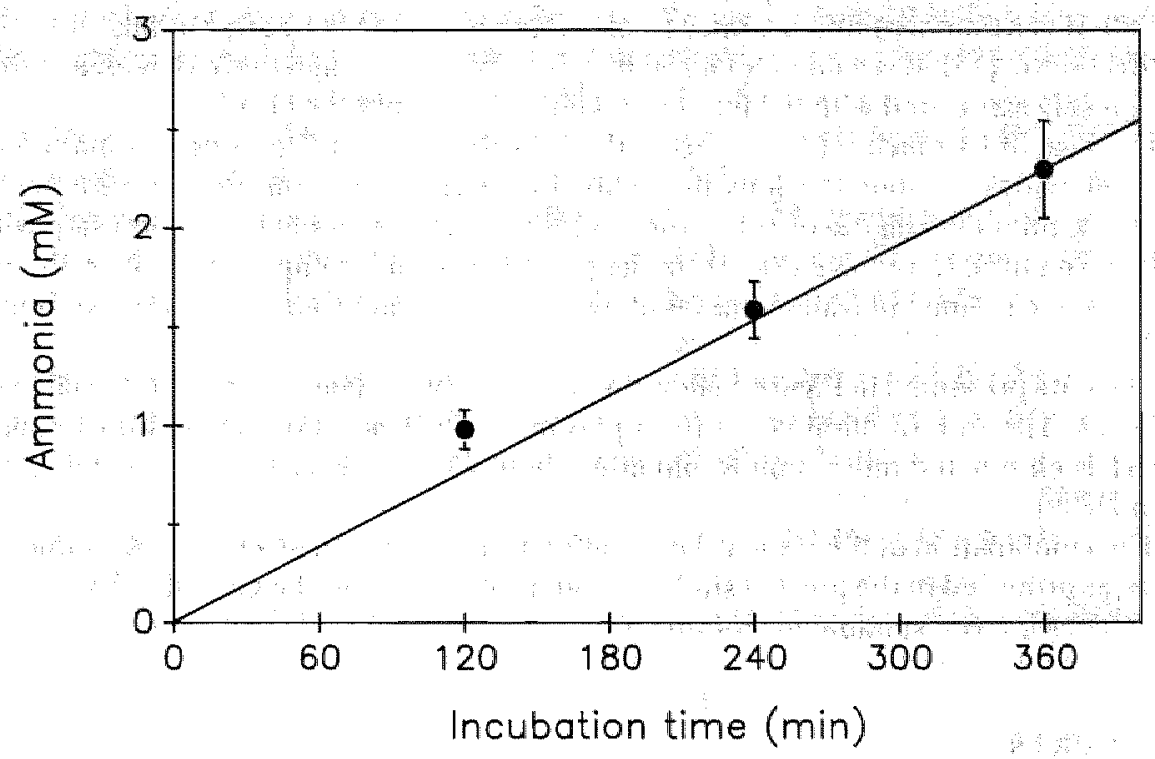

Figure 4. Limitation of incubation period as an alternative for sample dilution and for the purpose of screening.

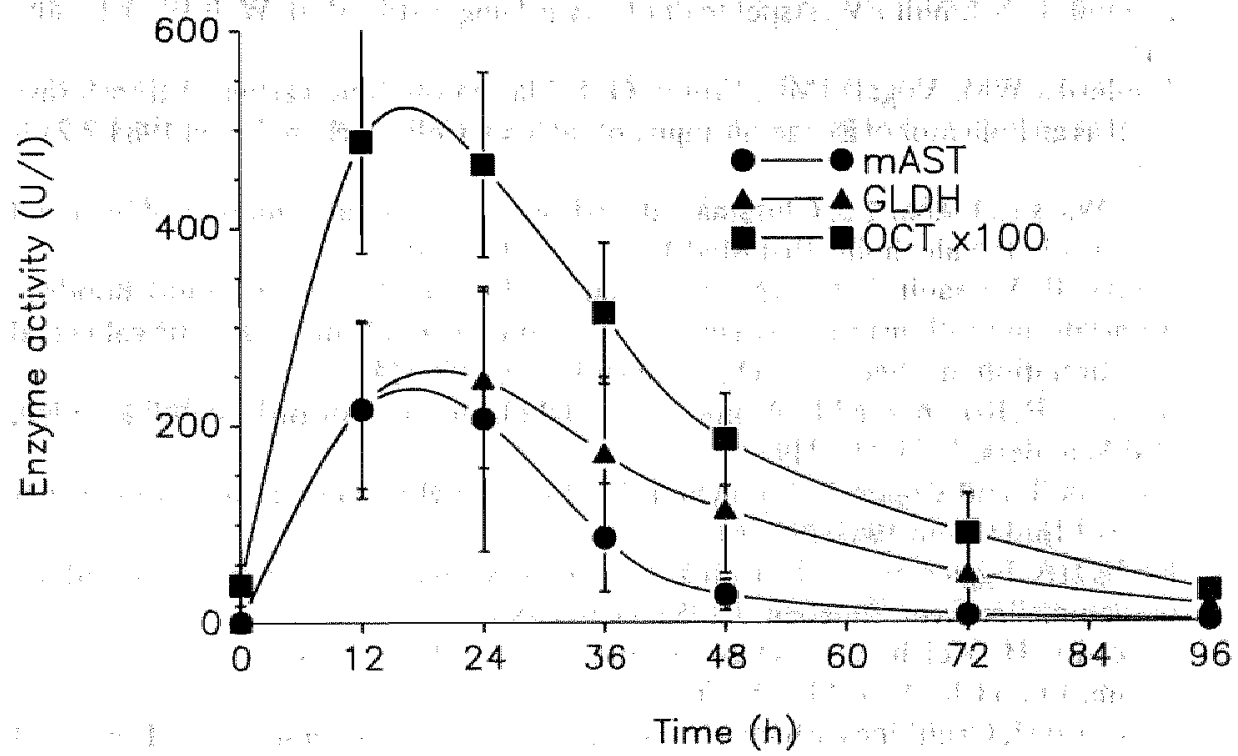

Figure 5. Plasma activities of three milochondrial enzymes in four patients with acute liver injury. Mean values $\pm S E M$ are shown. 
OCT is synthesized in the cytoplasm from three subunits with a molecular weight of 38,000 . It is assembled into a trimer (molecular weight 114,000) after uptake into the mitochondria [15]. It is a mitochondrial matrix enzyme, al though there is evidence that it is loosely associated with the inner mitochondrial membrane [18].

Because of its much higher velocity, the forward reaction allows determination of $O C T$ activities without the lengthy incubation period. For routine measurements, however, this advantage is offset by the necessity of an additional incubation step with urease, required to remove urea from the plasma or serum sample. Moreover, the instability of carbamyl phosphate necessitates fresh substrate solutions every two hours [11].

The data presented in Figure 5 show the simultaneous release of mitochondrial liver enzymes. The rate of elimination from plasma of OCT and GLDH is almost equal, mAST is eliminated more rapidly and after about $48 \mathrm{~h}$ levels have almost completely normalized.

The combination of the standard incubation procedure with an enzymatic ammonia assay, as proposed in the present study, considerably facilitates the OCT determination and makes it more suitable for routine use.

\section{REFERENCES}

1. Schmidt E, Schmidt FW. Aspekte der Enzym-Diagnostik. Med. Welt 1970;21:805816.

2. Frederiks WM, Vogels IMC, Fronik GM. Plasma onithine carbamyl transferase level as an indicator of ischaemic injury of rat liver. Cell Biochem Funct 1984;2:217220.

3. Van Waes L, Lieber CS. Glutamate dehydrogenase: a reliable marker of liver cell necrosis in the alcoholic. Brit Med J 1977; 2:1508-1510.

4. Nalpas B, Vassault A, Charpin S, Lacour B, Berthelot P. Serum mitochondrial aspartate aminotransferase as a marker of chronic alcoholism: diagnostic value and interpretation in a liver unit. Hepatology 1986;6:608-614.

5. Scriver CR, Rosenberg L.E. Amino acid metabolism and its disorders. Philadelphia, WB Saunders, 1973:234-249.

6. Grisiola $S$, and Cohen $P$, Catalytic role of carbamyl glutamate in citrulline synthesis.J Biol Chem 1952;198:561-565.

7. Krebs HA, Eggleston LV, Knivett VA, Arsenolysis and phosphorolysis of citrulline in mammalian liver. Biochem J 1955;59:185-193.

8. Reichard $H$, Reichard $P$, Determination of ornithine carbamyl transferase in serum. J Lab Clin Med 1958;52:709-717.

9. Reichard $\mathbf{H}$, Ornithine carbamyl transferase activity in human serum in diseases of the liver and the biliary system. J Lab Clin Med 1961;57:78-87.

10. Brown RW, Grisiola S, Ornithine transcarbamylase activity in serum. J Lab Clin Med 1959;54:617-620. 
11. Ceriotti $G$, Ornithine carbamyl transferase. In: Bergmeyer HU, Methoden der Enzymatischen Analyse. Weinheim/Bergstr.: Verlag Chemie, 1974;732-739.

12. Kontinnen A, Simple method for the determination of ornithine transcarbamylase activity in serum. Clin Chim Acta 1967;18:147-150.

13. Da Fonseca- Wollheim F, Direkte Plasmaammoniakbestimmung ohne Enteiweissung.Z Klin Chem Klin Biochem 1973;10:426-431.

14. Sakakibara S, Shiomi S, Kobayashis, Ikeda T, Irrai S, Kagamiyama H, A convenient and sensitive method for the determination of serum aspartate aminotransferase isozymes after electropheresis. Clin Chim Acta 1983;133:119-123.

15. Kalousek F, Francois B, Rosenberg LE. Isolation and characterization of ornithine transcarbamylase from normal human liver. J Biol Chem 1978;253:3939-3944.

16. Korzenovsky M, Werkman C, Conversion of citrulline to ornithine by cell-free extracts of Str.lactis. Arch Biochem Biophys 1953;46:174-185.

17. Schimke RT, Ornithine Carbamyltransferase (Mycoplasma). In: Colowick SP, Kaplan NO, eds. Methods in Enzymology, Vol. XXVIIA. New York: Ac. Press, 1970:295-297.

18. Powers-Lee SG, Mastico RA, Bendayan M. The interaction of rat liver carbamoyl phosphate synthetase and ornithine transcarbamoylase with inner mitochondrial membranes. J Biol Chem 1987; 262:15683-15688. 


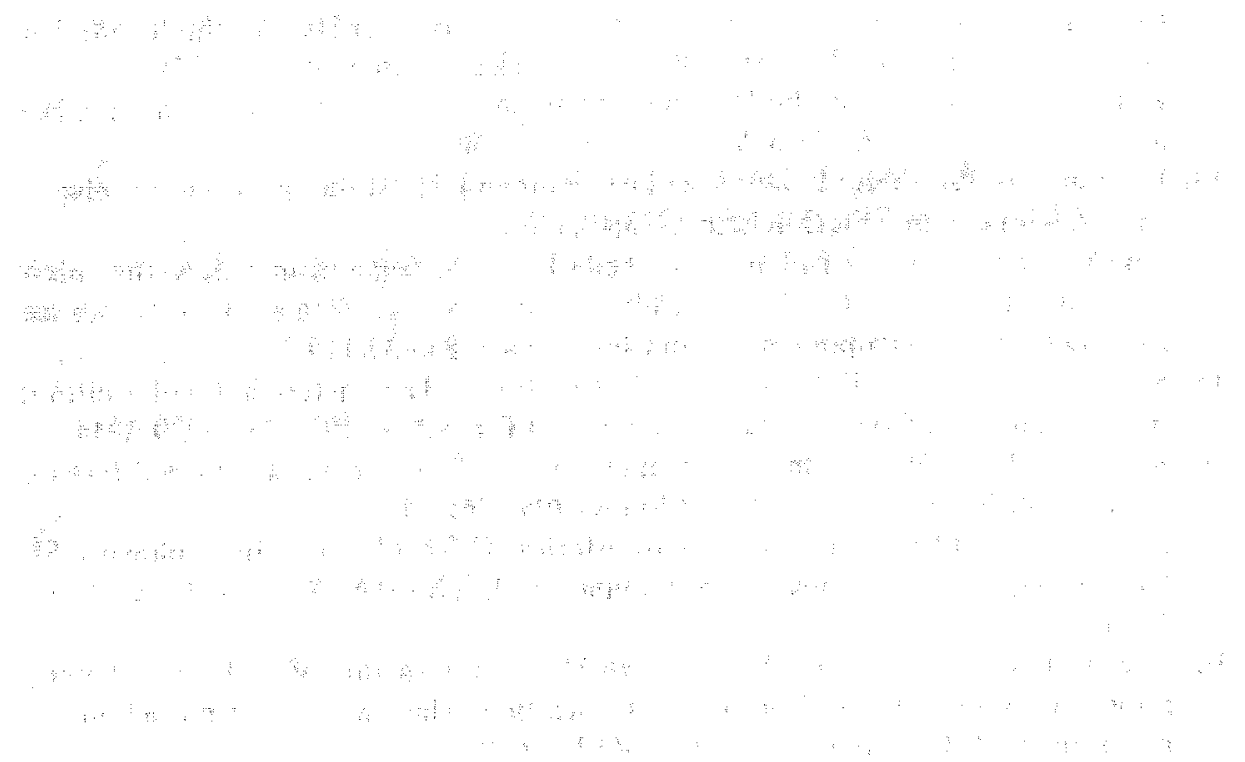

$\because$ 


\title{
CHAPTER 3
}

\section{Estimation of the Fractional Catabolic Rate Constants (FCR's) for the}

\author{
Elimination of Cytosolic Liver Enzymes from Plasma
}

Henny G. Peltenburg, Wim Th. Hermens, George M. Willems, J. Guus Flendrig, and Ellen Schmidt. Hepatology (in press).

\section{INTRODUCTION}

Patterns of hepatic enzyme release play an important role in the diagnosis and management of liver disease. For instance, the ratio of plasma activities of aspartate aminotransferase (AST) and alanine aminotransferase (ALT) has been used to differentiate between various forms of hepatitis and alcoholic liver disease [1-5]. It has long been realized, however, that the level of enzyme activity in plasma depends not only on the total released activity but also on the rate of catabolism of enzyme in the circulation, transcapillary escape of activity to the extravascular enzyme pool and extravascular return of activity to plasma. If a rapidly eliminated and a slowly eliminated enzyme are released together, a sudden type of release will result in a ratio of plasma activities approximately equal to the true proportion of released activities. If the release occurs more slowly, as during a chronic type of liver injury, the rapidly eliminated enzyme will show a relatively low plasma level because a larger fraction of its activity will have been eliminated during the longer time interval. The ratio of plasma enzyme activities can thus be determined by the time course of release and need not reflect the true ratio of relleased enzyme activities. Elimination of such uncertainties requires reliable values for the Fractional Catabolic Rate constants (FCR's) for the elimination of enzyme activities from plasma. By means of these values one may then calculate cumulative release of different hepatic enzymes in plasma. Thus it may be decided whether various forms of liver disease indeed result in altered proportions of enzyme release or not. At present, the values for FCR of most liver enzymes are unknown. The apparent disappearance rates from plasma have been measured in a few studies $[6,7,8]$, but these rates are lower than the catabolic elimination rates as will be discussed below. Recently, a method was introduced allowing estimation of FCR values for simultaneously released myocardial enzymes in patients with acute myocar- 
dial infarction [9,10]. Myocardial infarction is ideally suited for the application of this method because of its regular pattern of enzyme release with a well defined starting point and a rapid termination of release. In the present study this method is applied to liver enzymes. To be able to do so one has to select patients with an acute, short lasting period of hepatic enzyme release.

\section{PATIENTS AND METHODS}

\section{Estimation of Fractional Catabolic Rate constants}

The estimation method is described in ref.[9]. It can be shortly explained with the two-compartment circulatory model shown in Figure 1. Enzymes released from liver cells in plasma, i.e. the input, are subject to catabolism with a Fractional Catabolic Rate constant FCR, extravasation with a fractional Transcapillary Escape Rate constant TER and return from the extravascular pool to plasma with a fractional Extravascular Return Rate constant ERR. Although such a two-compartment model is obviously a simplification of the physiological situation, it allows adequate description of circulating enzymes (cf.[11] for a review). If the release of enzyme activity in plasma starts at time $t=0$, the cumulative release per liter of plasma up to time $t$ is given by:

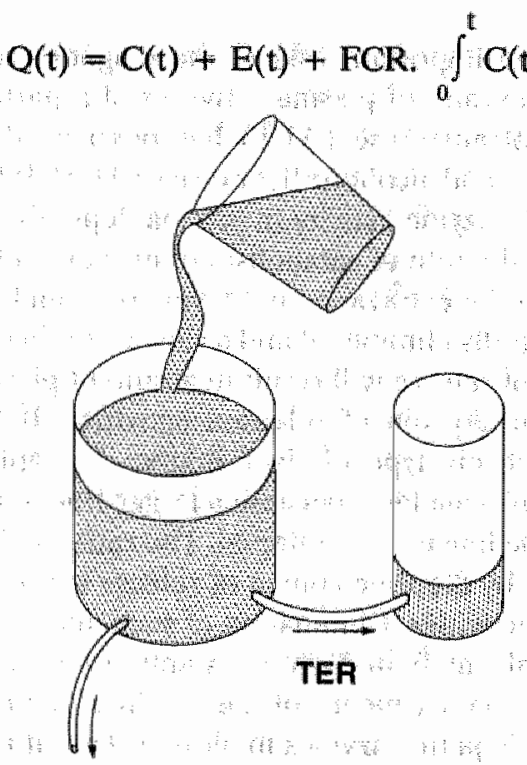

FCR

Filling Phase

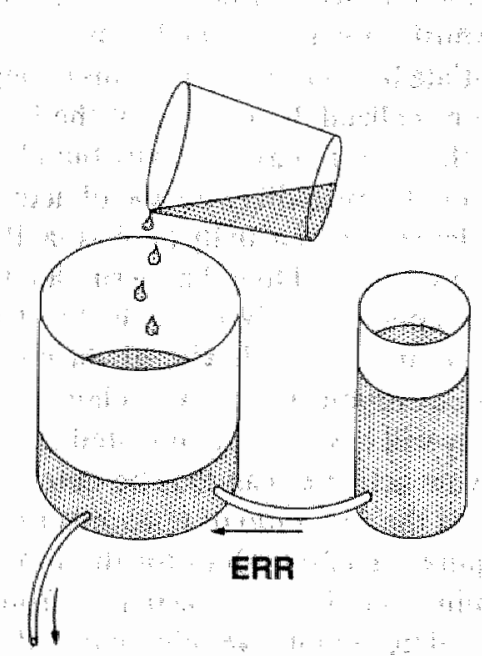

FCR

B

Elimination Phase

Figure 1. The two compartment model. The rapid release of enzymes into plasma during the filling phase A results in high plasma activities, while the extravascular pool is not yet saturated. During the elimination phase $\mathbf{B}$ this situation is reversed. Some tailing release may occur during phase $\mathbf{B}$. 
where $C(t)$ is the plasma activity of enzyme in units per liter of plasma measured at time $t$ and the last term is the quantity of enzyme eliminated from plasma up to time $t$. The extravascular pool $\mathrm{E}(\mathrm{t})$ is determined by the time course of $\mathrm{C}(\mathrm{t})$ and the values of the exchange parameters TER and ERR. It can be calculated from the equation [9]:

$$
E(t)=T E R \cdot \exp (-E R R \cdot t) \int_{0}^{t} \exp (E R R . t) C(t) d t
$$

The values of TER and ERR are not different for enzymes with a molecular weight of $\mathrm{M}=100,000-160,000$ as presently studied and fixed values of $T E R=0.014 \mathrm{~h}^{-1}$ and $E R R=0.018 h^{-1}$ can be used $[10,11]$. Values of $C(t)$ in equations 1 and 2 are obtained by subtraction of the normal, pre-elevation, plasma activities from the plasma activities actually measured.

If two different enzymes, numbered 1 and 2 , are released simultaneously and in a fixed proportion, one may write $Q 1(t)=r . Q 2(t)$ with $r$ the ratio of released activities. Inserting equation (1) in this relation one obtains an expression of the following form:

$$
\begin{array}{lc}
y(t)=P_{1} x_{1}(t)+P_{2} x_{2}(t)+P_{3} x_{3}(t) & \\
\text { with } y(t)=C_{1}(t)+E_{1}(t) & P_{1}=r \\
x_{1}(t)=C_{2}(t)+E_{2}(t) & P_{2}=r . F C R_{2} \\
x_{2}(t)=\int_{0}^{t} C_{2}(t) d t & P_{3}=-F C R_{1} \\
x_{3}(t)=\int_{0}^{1} C_{1}(t) d t &
\end{array}
$$

The functions $y(t), x_{1}(t), x_{2}(t)$ and $x_{3}(t)$ in equation 3 can be calculated from the measured enzyme activites $C_{1}(t)$ and $C_{2}(t)$ and the fixed values of TER and ERR. Thus the unknown parameters $P_{1}, P_{2}$ and $P_{3}$ in equation 3 can be estimated by a standard linear regression procedure minimizing the difference between the right hand and left hand side of equation (3) over all data points. The quality of the obtained fit is expressed in the "residue",i.e. the mean deviation per data point expressed as a percentage. In this way the values of both fractional catabolic rate constants FCR 1 and FCR2, and the ratio of released activities $\mathrm{r}$ are obtained simultaneously: These parameters can be estimated even in case of tailing release of liver enzymes during the elimination phase (cf. right hand panel Fig.1). The method works best if one of the enzymes, usually indicated as reference enzyme 1 , is eliminated much slower from plasma than enzyme $2\left(\mathrm{FCR}_{1}<<\mathrm{FCR}_{2}\right)[12]$.

\section{Patient selection and collection of plasma samples}

The estimation method requires a well-defined initial upstroke of the time-activity curves in order to determine the ratio ( $r$ ) of released activities. In addition, although some tailing release is allowed, a rapid elimination phase of enzyme activity from plas- 
ma must also occur because the disappearance from plasma must be mainly determined by the values of FCR and not just reflect tapering enzyme release from injured liwer cells. The most suitable condition for the estimation procedure will thus be a sirigle, short-lasting, burst of enzyme release rather than the more chronic types of release which are more common in liver disease. Potential candidates for the fulfillment of these criteria, entering the Department of Internal Medicine of the University Hospital Maastricht between May 1st 1986 and December 1st 1987, were asked for informed consent. Venous samples of $10 \mathrm{ml}$ of blood were obtained approximately every 8-12 hours. The sample schedule was synchronized such that one of the two daily samples could be taken at the routine blood collection for the climical laboratory. Sampling was continued for one to two weeks depending on the routine enzymatic data. Clotting of blood samples was prevented by heparin $(200 \mathrm{U} / \mathrm{l})$ and the samples were kept at $4^{\circ} \mathrm{C}$ for at most 12 hours. Plasma was then separated from the blood cells by centrifugation for $10 \mathrm{~min}$ at $1000 \mathrm{xg}$ and stored at $-20^{\circ} \mathrm{C}$.

Data from 40 patients were thus obtained and a final selection of 10 patients was made satisfying the following criteria:

- the presence of a rapid initial phase of increasing plasma activities with peak values reached within 2 days after the start of sampling.

- the presence of a subsequent rapid disappearance phase with apparent elimination rates exceeding $4 \%$ /hour for LDH and AST and $1 \%$ /hour for ALT.

- maximal plasma activities exceeding $500 \mathrm{U} / \mathrm{l}, 100 \mathrm{U} / \mathrm{l}$ and $75 \mathrm{U} / \mathrm{l}$ for respectively $\mathrm{LDH}$, AST, ALT.

- sampling intervals not exceeding 16 hours in the first 4 days.

- no indication for damage to organs other than the liver as evidenced, for instance, by normal creatine kinase levels.

- patients with significant sequestration of fluid (e.g. ascites) were excluded because of possible invalidation of the two-compartment model in such patients [11].

\section{PATIENTS}

- Patient 1 was a 63 year old woman with acute right sided abdominal pain lasting for about 5 hours. Ultrasonic investigation revealed a dilated biliary duct without gall stones. She was diagnosed as a case of billiary obstruction followed by a successful biliary colic.

- Patient 2 was a 49 year old woman admitted to the intensive care unit for circulatory fallure secondary to sepsis. Rapidly increasing liver enzymes indicated hepatic ischemia. The period of circulatory failure lasted for $1.5 \mathrm{~h}$.

- Patient 3 was a 90 year old woman with choledocholithiasis. After papillotomy enzyme activities in plasma normalized rapidly. 
- Patient 4 was a 60 year old woman admitted to the intensive care unit for circulatory failure of unknown cause. There was a rapid response to therapy. The patient developed liver ischemia during the period of shock.

- Patient 5 was a 40 year old woman with respiratory failure due to an exacerbation of chronic obstructive lung disease. Liver enzymes were elevated due to a short period of right sided heart failure.

- Patient 6 was a 71 year old woman with circulatory failure due to gramnegative septicaemia. The period of shock lasted approximately 1 hour.

- Patient 7 was a 92 year old man with postoperative respiratory failure followed by hemodynamic instability. During a short period of hypotension the patient developed liver ischemia.

- Patient 8 was a 67 years old woman with liver ischemia due to septic shock. Duration of hypotension was estimated at 2 hours.

- Patient 9 was a 62 year old man with a brief period of severe hypotension during a tachycardia from an overdose of verapamil.

- Patient 10 was a 72 years old man who developed liver ischemia several weeks after a silent myocardial infarction resulting in theart failure.

\section{Determination of enzyme activities in control livers}

Liver samples were collected post mortem from six patients. Two patients had lung cancer, without liver metastases; one patient died suddenly after massive pulmonary embolism and the three remaining patients died acutely after cerebral vascular accident, ruptured aortic aneurysm and myocardial infarction. After death corpses were transported to the morgue within 3-6 hours and kept there at $4{ }^{\circ} \mathrm{C}$ until autopsy was performed within 18 hours. No effect of autolysis time on liver enzyme activities was apparent during this period. A slice of one $\mathrm{cm}$ thickness was taken from the right liver lobe and accepted for investigation if routine histological examination did not reveal any abnormality. Slices were stored at $-20^{\circ} \mathrm{C}$ for a period not exceeding 4 months. It was verified that such storage times did not lower tissue enzyme activities. At the time of enzyme determinations the slice was allowed to thaw at room temperature. Three tissue samples of approximately $1.5 \mathrm{gram}$ of wet weight each were taken from different sites of the slice. Each sample was homogenized and subsequently sonicated in $20 \mathrm{ml}$ of Tris-HCl buffer $(0.05 \mathrm{M} ; \mathrm{pH}=8.5)$ containing $0.05 \mathrm{M} \mathrm{NaCl}, 3 \mathrm{mM}$ mercaptoethanol and 0.015 mM pyridoxal-5-phosphate. Homogenization was performed in 3 bursts of 7 s with intervals of $7 \mathrm{~s}$, using a Janke \& Kunkel Ultraturrax type 18-10. Sonification at 5 $s$ bursts with intervals of $5 \mathrm{~s}$ during 3 min, using a 150 W MSE Mark II desintegratot, Homogenization and sonification was performed in plastic tubes kept on ice. The sonicate was centrifuged for 3 min at $1500 \mathrm{xg}$ and the supernatant was mixed with an equal volume of a pasteurized plasma solution (PPF Central Laboratory of the Blood Transfusion Laboratory, Amsterdam). Enzyme activities were determined either directly or, after storage at $-20^{\circ} \mathrm{C}$, the next day and expressed in tuits per gram of wet weight. 


\section{Determination of enxyme activities}

Enzyme activities of aspartate aminotransferase (AST, EC 2.6.1.1), alanine aminotransferase (ALT; EC 2.6.1.2) and lactate dehydrogenase (LDH; EC 1.1.1.27) were determined spectrophotometrically using commercially awailable testkits (Boehringer, Mannheim).

Measurements were performed in a Cobas Bio centrifugal analyzer (Hoffmann-La Roche) at $25^{\circ} \mathrm{C}$ and expressed in micromoles of substrate converted per minute per liter of plasma (UA). Normal plasma activities in healthy controls were 5-15 U// for AST, 5-18 U/A for ALT and 40-250 U/A for LDH, Isoenzymes of AST and LDH were separated by electrophoresis (Beckman, type P/N 65580) on agarose gels (Beckman, Paragon-LD) and scanned at a wavelength of $632 \mathrm{~nm}$ in a densitometer (LKB, type 2202). The separation of cytosolic and mitochondrial AST, resp. cAST and mAST, was performed according to ref [13] and the separation of the isoforms $\mathrm{LDH}_{1}$ to $\mathrm{LDH}_{5}$ according to ref. [14]. The presence of a 10-20\% fraction of mitochondrial ALT has been demonstrated in liver tissue of several species [15] but was not confirmed in human liver [16]. This isoenzyme is very labile and, if present in liver or plasma, would be inactivated by freezing of samples. Accordingly the present study only considers cytosolic ALT activity.

Enzyme determinations were performed within 6 months after collection of plasma samples and it was verified that this period of storage had no effect on the plasma activities of AST and LDH. In contrast, however, the plasma activities of ALT showed a gradual inactivation during storage at $-20^{\circ} \mathrm{C}$ with a half-life time of approximately 6 months. In order to correct for this inactivation the ALT activity in 3-6 plasma samples per patients was also determined directly after sample collection and used to calculate a correction factor per patient.

In several patients the first one or two samples were taken in the ward, directly after admission to hospitall, before the patient was classified as a potential candidate. Enzyme activities in these early samples were determined at the department of Clinical Chemistry, using identical equipment and test kits as described but at a temperature of $37^{\circ} \mathrm{C}$. These data were also used after multiplication of AST, ALT and LDH activities with temperature conversion factors of respectively $0.505,0.550$ and 0.554 . It was checked that the error introduced by this procedure did not exceed $10 \%$.

\section{Comparison with earlier published data}

A comparison was made with the plasma time-activity curves of 5 patients with acute liver injury hospitalized in the Medizinische Klinik of the Hannover Hochschule. These data have been published earlier in ref. [7]. This study included four patients with an episode of acute right sided heart failure and one patient after surgical removal of an ecchinococcus cyst: These patients were selected on rapid elimination of enzyme activities from plasma. 


\section{RESULTS}

Fig.2 shows the mean time-activity curves of LDH, AST and ALT measured in the 10 selected patients. The quick upstroke and rapid elimination of activity from plasma, essential for the application of the fitting procedure, are apparent. Separation of LDHisoenzymes showed that the elevations of plasma LDH activities consisted mainly (more than $80 \%$ ) of LDHs up to three days after the acute event, which is consistent with the isoenzyme composition of the liver (cf. Table 2). It was not attempted to correct the total LDH elevations for the small percentages of isoenzymes other than LDHs because the increased scatter introduced by the electrophoretic separation procedure would offset the advantage of such a correction [12]. However, the values of FCR(LDH) obtained from the fit is essentially the catabolic rate constant for LDHs, as indicated in Table 1. As shown in Fig.2, the activities of LDH reach a temporary plateau value at about 100 hours before further return to normal. This could indicate some minor release of $\mathrm{LDH}_{1}$ and $\mathrm{LDH}_{2}$ which are eliminated very slowly from plasma [7]. In order to minimize a possible effect of this phenomenon on the obtained parameter values, the fitting procedure for LDH was limited to 100 hours.

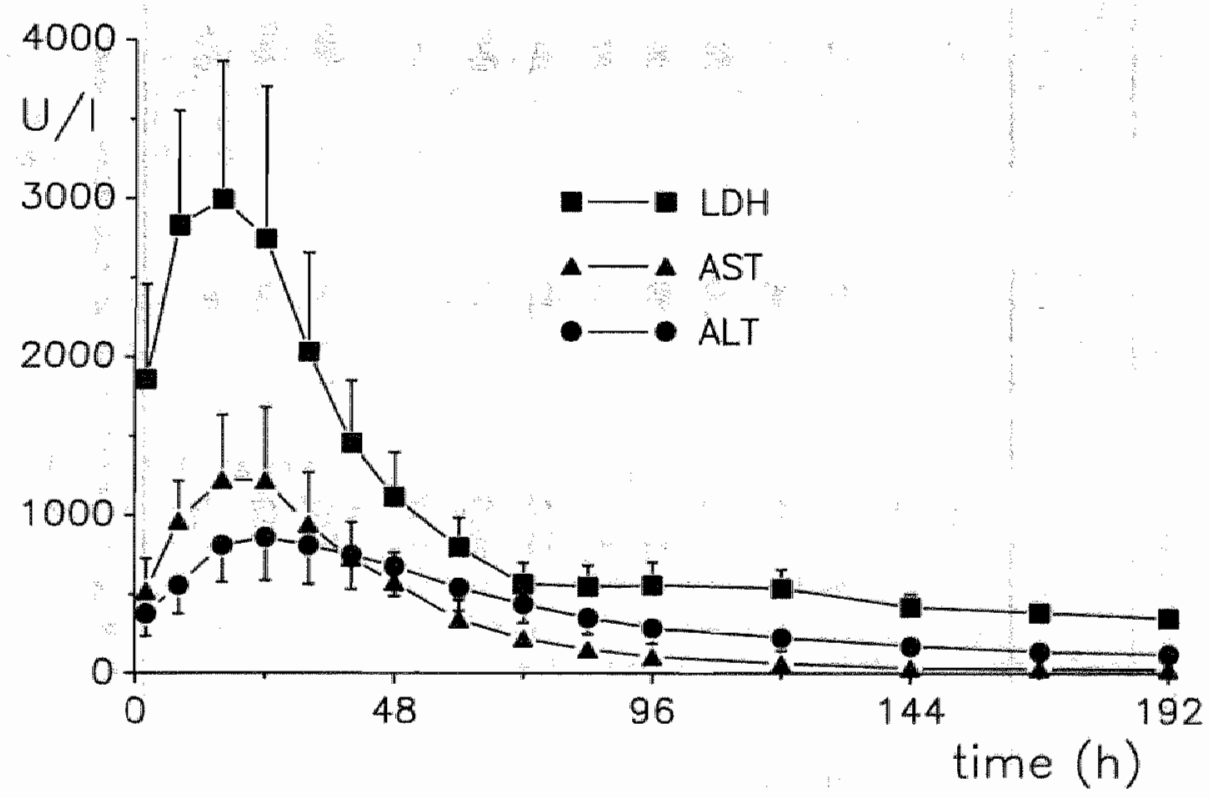

Figure 2. Mean activities of LDH, AST and ALT observed after acute liver injury. Standard error of the mean (SEM) is indicated $(\mathrm{n}=10)$. 


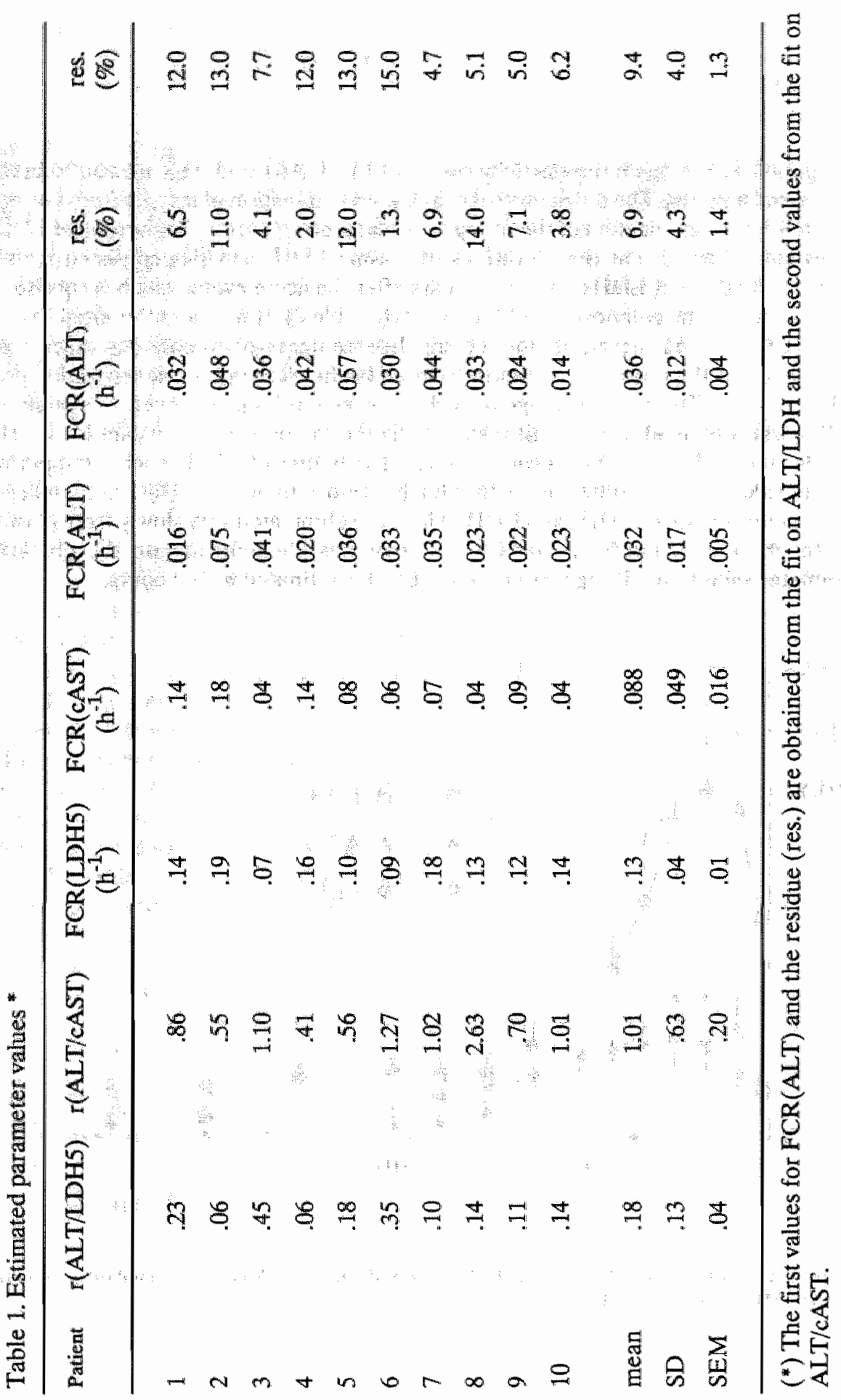



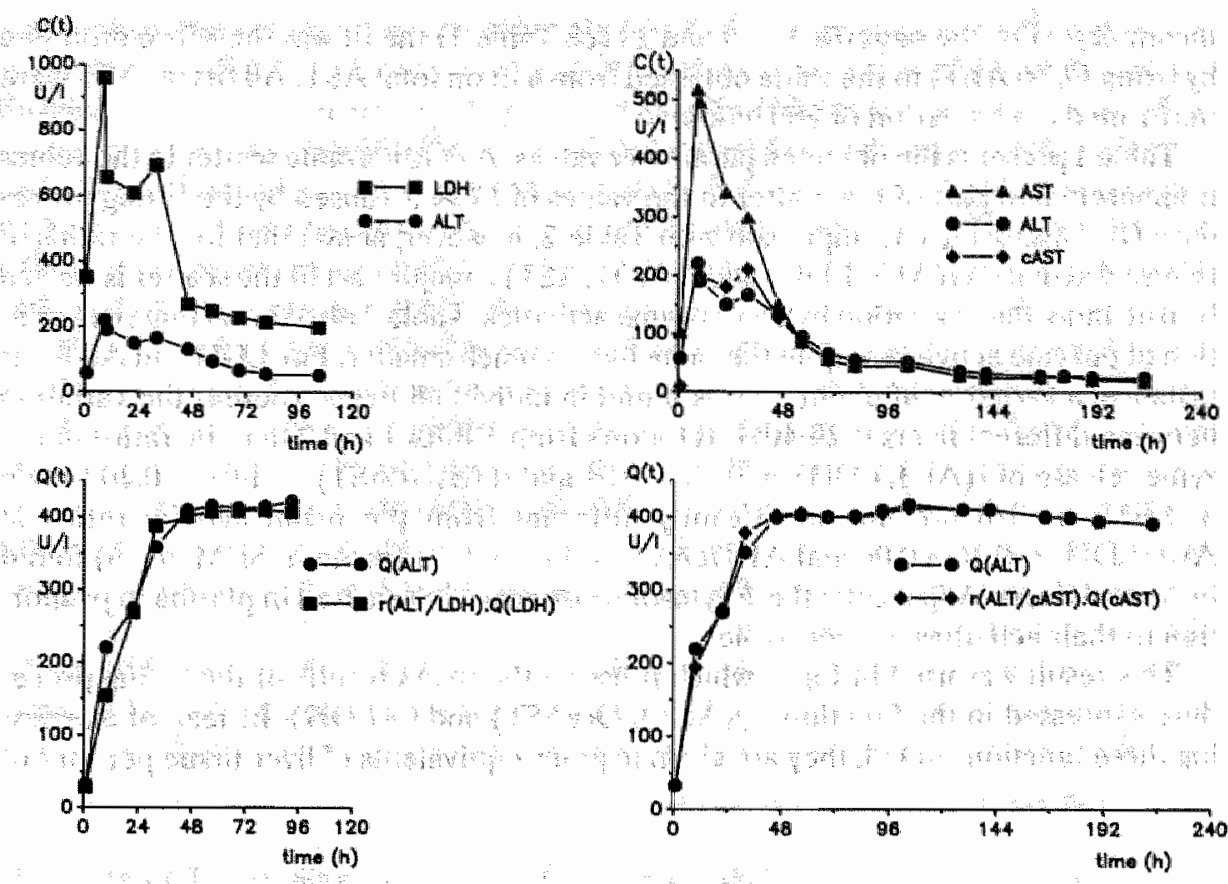

Figure 3. Results of the fitting procedure for patient no.5. Plasma activities are shown in the upper panel. The lower panel shows the obtained fit. The mean deviation per data point (residue) in this patient was $12 \%$ for ALT/LDH and $13 \%$ for ALT/CAST. Total AST activity has been added to the upper right hand figure. Note that the contribution of mAST to total AST activity is virtually limited to the first 48 hours.

The contribution of mAST was sometimes more than $50 \%$ of total AST elevations. However, this was only a temporary effect. Apparently, mAST is eliminated from plasma faster than cAST and after 48 hours the contribution of mAST is usually less than $15 \%$.

Fig. 3 presents an example of the fitting procedure for patient 5 . This patient was chosen because the mean residue of $12.5 \%$ was the largest (cf. Table 1) and accordingly this patient showed the worst fit. The upper panel of Fig. 3 shows the plasma activity curves to which the fit was applied, while the lower panel presents the obtained results expressed in the functions $y(t)-P_{3} x_{3}(t)=Q_{1}(t)$ and $P_{1} x_{1}(t)+P_{2} x_{2}(t)=r \cdot Q_{2}(t)$ which are made approximately equal to each other as a result of the fitting procedure (cf. Methods). It is apparent from Fig. 3 that a fit on total AST activity, instead of cAST, would result in a large underestimation of $\mathrm{r}(\mathrm{ALT} / \mathrm{cAST})$ and in an overestimation of FCR(CAST). In contrast, such a fit does not introduce a bias in the value obtained for FCR(ALT) (cf. Table 1). This was used in some patients with incomplete cAST data. For the early samples, taken at the ward (cf. Methods), data on isoenzyme composition were not available and the early upstroke in the cAST curve was therefore sometimes 
incomplete. For the patients $4,6,9$ and 10 (cf. Table 1) the fit was therefore modified by fixing FCR(ALT) to the value obtained from a fit on total AST. All fits on AST were performed over a period of 200 hours.

Table 1 presents the obtained parameter values. A considerable scatter in the values is apparent and part of the scatter in the values of FCR is caused by the fitting procedure (cf. Discussion). Comparison with Table 2, however, shows that for the ratios of released activities $\mathrm{r}(\mathrm{ALT} / \mathrm{LDH})$ and $\mathrm{r}(\mathrm{ALT} / \mathrm{cAST})$ a major part of the scatter is caused by true individual variation in liver enzyme activities. Table 2 also shows that the variation of enzyme activities within the same liver is much smaller. For LDH and ALT, for instance, a variation of about $10 \%$ is found in individual livers whereas the variation between different livers is $20-40 \%$. It follows from Tables 1 and 2 that the ratios of enzyme release of $\mathrm{r}(\mathrm{ALT} / \mathrm{LDH})=0.18 \pm 0.04$ and $\mathrm{r}(\mathrm{ALT} / \mathrm{cAST})=1.01 \pm 0.20$ (mean $\left.\pm \mathrm{SEM}_{3} \mathrm{n}=10\right)$ are not significantly different from the mean activity ratios of $\mathrm{ALT} / \mathrm{LDH}=0.16 \pm 0.04$ and $\mathrm{ALT} / \mathrm{cAST}=1.05 \pm 0.21$ (mean $\pm \mathrm{SEM}, \mathrm{n}=6$ ) found in control livers. Apparently these cytosolic enzymes are released in plasma in proportion to their activities in liver tissue.

This result was used in Fig.4, which presents the mean results of the fitting procedure expressed in the functions $Q(A L T), Q(c A S T)$ and $Q(L D H)$. Instead of expressing these functions in $U / 1$, they are given in gram-equivalents of liver tissue per liter of

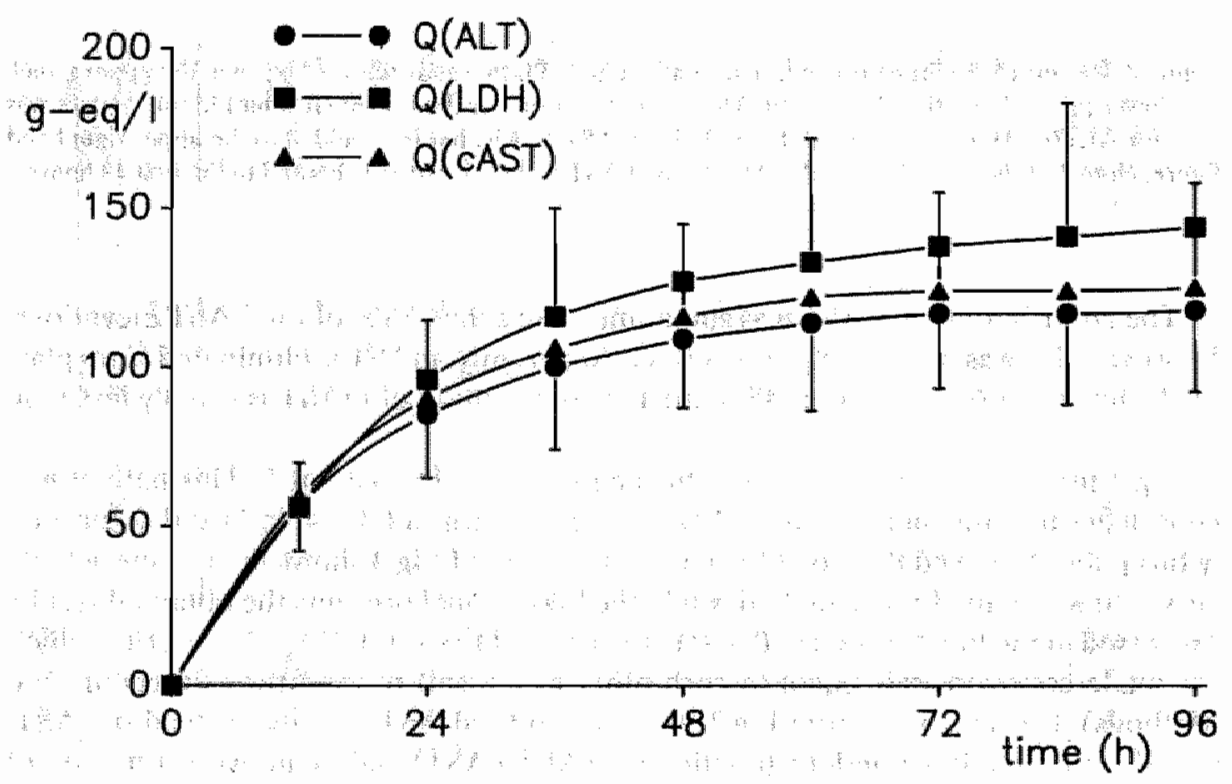

Figure 4. The extent of hepatic injury expressed in gram-equivalents of liver tissue per liter of plasma. Identical estimates are obtained from ALT, LDH and CAST. Mean values \pm SEM are indicated. A total amount of enzyme in more than $\mathbf{4 2 0}$ grams of liver tissue is found after multiplication with a mean plasma volume of 3 liter. 
Table 2. Enzyme activities in human control liwers $(\mathrm{n}=6)$ expressed in $U$ per gram of wet weight

\begin{tabular}{lcc}
\hline Enzyme & $\begin{array}{c}\text { mean activity (U/g) } \\
\pm \mathrm{CV}(\%)\end{array}$ & $\begin{array}{c}\text { mean CV (\%) in } \\
\text { individual livers }\end{array}$ \\
\hline ALT & $17 \pm 41(\%)$ & 10 \\
AST & $58 \pm 28(\%)$ & 16 \\
CAST & $16 \pm 25(\%)$ & 13 \\
mAST & $42 \pm 26(\%)$ & 14 \\
LDH & $117 \pm 19(\%)$ & 9 \\
LDH5 & $95 \pm 7(\%)$ & 5 \\
LDH4 & $9 \pm 24(\%)$ & 22 \\
LDH3 & $7 \pm 16(\%)$ & 33 \\
LDH2 & $5 \pm 32(\%)$ & 44 \\
LDH1 & $2 \pm 67(\%)$ & 89 \\
ALT/AST & $1.05 \pm 48(\%)$ & 9 \\
ALT/LDH5 & $0.16 \pm 56(\%)$ & 6 \\
\hline
\end{tabular}

plasma $(g-e q / 1)$. To this end, values of $Q(t)$ are divided by the activity per gram of wet weight i.e. respectively $17 \mathrm{U} / \mathrm{g}, 16 \mathrm{U} / \mathrm{g}$ and $117 \mathrm{U} / \mathrm{g}$ for respectively ALT, CAST and LDH (cf. Table 2) As shown in this figure, identical estimates of the extent of injury are obtained from the three different enzymes; Comparison of figures 1 and 4 shows that during the rapid elimination phase of LDH and AST from plasma, between 24 and 48 hours after the acute event, there is ongoing release of enzyme. It is this tailing release which causes underestimation of FCR if determined from apparent disappearance rates. It also follows from Fig. 4 that the mean extent of injury in the selected patients has been considerable and corresponds to the amount of enzyme in more than $400 \mathrm{~g}$ of liver tissue, if the mean plasma volume in these patients is estimated at 3 liter.

Table 3 shows a comparison of apparent elimination rates of enzyme activities from plasma with earlier published data [7]. Because of the missing upstroke in the earlier part of these curves, it was not possible to apply the fitting procedure. However, the fractional apparent disappearance constants $\mathrm{k}_{\mathrm{d}}\left(\mathrm{t} 1 / 2=\ln 2 / \mathrm{k}_{\mathrm{d}}\right)$ were calculated from logarithmic plots of the elimination phase and this was also done for the patients of the present study. Apart from the earlier mentioned tailing enzyme release there is also extravascular return of enzyme activity to plasma during the elimination phase. Both factors explain why values of $\mathrm{k}_{\mathrm{d}}$ in Table 3 are much lower than FCR. It follows from this table that the earlier published data are completely consistent with the present results. 
Table 3. Comparison of enzyme elimination rates $\left(\mathrm{h}^{-1}\right)$ in earlier published and present data (see text)

Data from present study

\begin{tabular}{llllllll} 
Patients & \multicolumn{2}{c}{ ALT } & \multicolumn{2}{c}{ AST } & \multicolumn{2}{c}{ LDH } \\
& $k_{d}$ & FCR & kd & FCR & $k_{d}$ & FCR \\
\hline 1 & 0.033 & 0.032 & 0.053 & 0.14 & 0.063 & 0.14 \\
2 & 0.025 & 0.048 & 0.053 & 0.18 & 0.063 & 0.19 \\
3 & 0.013 & 0.036 & 0.039 & 0.04 & 0.035 & 0.07 \\
4 & 0.011 & 0.042 & 0.041 & 0.14 & 0.046 & 0.16 \\
5 & 0.017 & 0.057 & 0.027 & 0.08 & 0.063 & 0.10 \\
6 & 0.041 & 0.030 & 0.043 & 0.06 & 0.043 & 0.09 \\
7 & 0.017 & 0.044 & 0.041 & 0.07 & 0.053 & 0.18 \\
8 & 0.020 & 0.033 & 0.035 & 0.04 & 0.041 & 0.13 \\
9 & 0.050 & 0.024 & 0.050 & 0.09 & 0.058 & 0.12 \\
10 & 0.012 & 0.014 & 0.033 & 0.04 & 0.063 & 0.14 \\
& & & & & & \\
mean & 0.024 & 0.036 & 0.042 & 0.088 & 0.053 & 0.13 \\
SEM & 0.004 & 0.004 & 0.003 & 0.016 & 0.004 & 0.01 \\
\hline
\end{tabular}

Earlier published data $[6]$

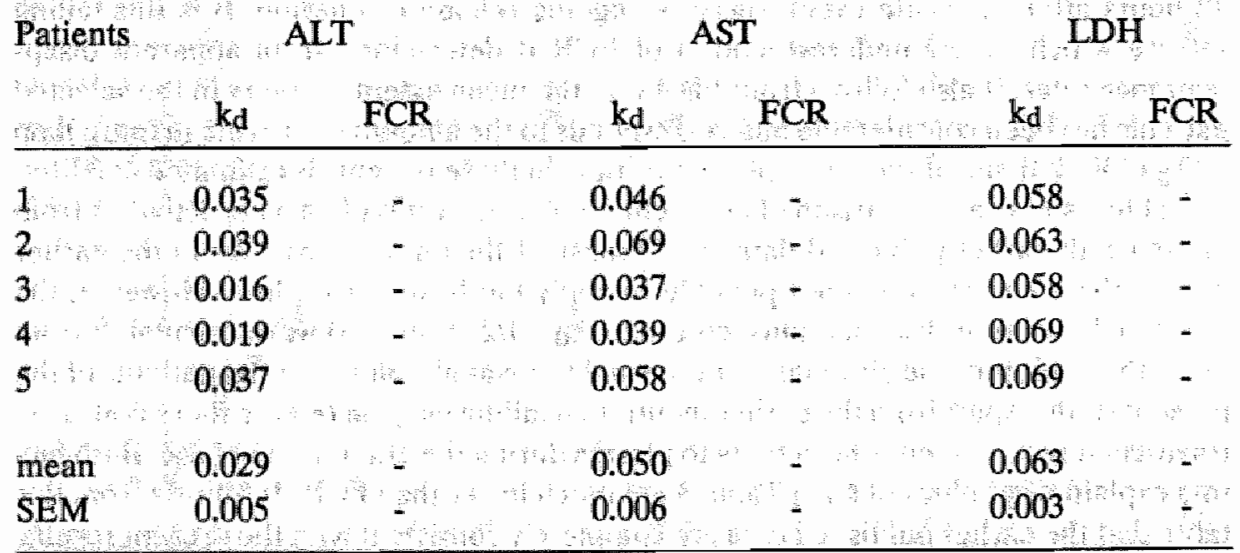




\section{Discussion}

The two-compartment model and the estimation procedure based on it are dependent on certain assumptions. These include intravascular input of enzymes released by the liver and the simultaneity of release of different enzymes.

In the liver the blood stream is separated fromliver cells by a highly fenestrated endothelial layer and the so called space of Disse. The intimate contact of blood with this 'paravascular' space and the absence of a basal membrane, favors immediate entry of released enzymes from damaged hepatocytes into the blood stream [17]. Enzymes transported from the liver by the lymphatic pathway [18], enter the plasma relatively fast by way of the thoracic duct [19]. Taken together, these features of hepatic circulation ensure rapid transport of liver enzymes to plasma.

Evidence for the simultaneity of enzyme release is supported by observations on the release of enzymes from isolated perfused liver preparations. These studies have shown some dependence of the rate of outflow on molecular weight, larger molecules showing a relative retardation [20], but this effect was negligible for AST, ALT and LDH with molecular weights in the narrow range of $M=100,000-160,000$.

The estimation method applied in the present study was first used for patients with acute myocardial infarction and is more difficult to apply to patients with liver injury. After myocardial infaretion the time of onset of injury is usually known and the release of myocardial enzymes shows a sudden and well-defined pattern [9]. Also, the release lasts for a short period of time ( $2-4$ days), which allows frequent sampling of plasma enzyme activities. Because of the rapid termination of myocardial enzyme release one obtains activity curves with down-slopes that are mainly determined by the values of FCR and these values can thus be estimated accurately. In contrast, hepatic injury usually results in a more chronic pattern of enzyme release and the time of onset of release is often uncertain. Frequent sampling of plasma enzyme activities is unpracticable for longer periods of time and the activity curves obtained will thus be less wellsampled than those obtained after myocardial infarction. Even if sudden hepatic injury results in well-defined peaks of plasma enzyme activities, the down slope is often slow and determined by gradually diminished hepatic enzyme release, rather than by the FCR values. Due to these circumstances, few patients with liver injury can be used for the fitting procedure.

After myocardial infarction a value of FCR(AST) $=0.093 \mathrm{M} \pm 0.006 \mathrm{~h}^{-11}($ mean \pm SEM, $\mathrm{n}=10$ ) was obtained. As it has been shown [21] that release of mAST after myocardial infaretion is minimal, this value can be taken as FCR(CAST). Comparison with the value of FCR(CAST) $=0.088 \pm 0.016 \mathrm{~h}^{-1}$ (mean $\pm S E M, n=10$ ) found in the present study shows that both values are identical but the less ideal sampling conditions in patients with acute liver injury probably introduce a somewhat larger experimental scatter. For FCR(LDH) and FCR(ALT), no earlier estimates have been published but several authors have estimated the apparent disappearance rates of these enzymes from plasma after short, well-defined periods of acute liver damage. In 
Table 3 it was shown that the data published earlier in ref. [7] are consistent with the present study. The same is true for values of $k_{d}(A L T)=0.028 \pm 0.010 \mathrm{~h}^{-1}$ and $k_{d}$ (AST) $=0.034 \pm 0.005 \mathrm{~h}^{-1}$ (mean $\pm \mathrm{SEM}, \mathrm{n}=9$ ) published in ref [6], although a value of $\mathrm{kd}(\mathbf{L D H})=0.012 \pm 0.001 \mathrm{~h}^{-1}$ published in this study indicates that some ongoing release of liver enzymes must have occurred. The high mean value $\mathbf{k}_{d}(\mathrm{LDH})=0.09$ $\mathrm{h}^{-1}$ published in ref. [8] of patients with Amanita mushroom intoxication indicates that the LDH release must:indeed have stopped abruptly. oM

In the present study the patients used for the estimation procedure suffered either from acute biliary obstruction or from a short period of shock resulting in ischemic liver injury. Pre-existent changes in liver enzyme activities are improbable in such patients and it is therefore not surprising to find that the ratios of released activities did not differ significantly from the activity ratios in control livers. As mentioned in the introduction, differences in hepatic enzyme activity ratios are suggested by clinical enzymatic indices in various forms of hepatic disease. With the FCR values determined in the present study it is possible to estimate cumulative release in these patients and to decide whether such altered ratios actually reflect hepatic changes or must be ascribed to differences in the time course of hepatic enzyme release.

\section{REFERENCES}

1. De Ritis F, Coltorti M, Giusti G. An enzyme test for the diagnosis of viral hepatitis: the transaminase serum activities. Clin Chim Acta 1957; 2:70-74.

2. Schmidt E, Schmidt FW. Clinical Pathology of Viral Hepatitis. In: Deinhardt F, Deinhardt J, eds. Viral Hepatitis: Laboratory and Clinical Science. New York: Marcel Dekker, 1983:411-487.

3. Schmidt E, Schmidt FW. Lebererkrankungen. In: Bergmeyer HU, ed. Methoden der enzymatischen Analyse, Band I 3rd ed. Weinheim Bergstr.: Verlag Chemie, 1974:14-29.

4. Cohen JA, Kaplan MM. The SGOT/SGPT ratio - an indication of alcoholic liver disease. Dig Dis Sci 1979; 24:835-838.

5. Schmidt E, Schmidt FW. Aminotransferases in human pathology and clinical chemistry. In: Christen P, Metzler DE, eds. Transaminases. New York: John Wiley \& sons, 1985:587-624.

6. Amelung D. Enzymelimination aus der Plasma. In: Schmidt FW, ed. Praktische enzymologie. Bern: Hans Huber, 1968:149-162.

7. Bär U, Ohlendorff S. Studien zur Enzymelimination. Klin Wschr 1970; 48:776-779.

8. Fröhlich Ch; Kurrle E. Zur Bedeutung unterschiedlicher Eliminationskonstanten von LDH-isoenzymfraktionen für die Zusammensetzung der SLDH-Verteilungsmuster beim Menschen. Klin Wschr 1969; 47:903-909.

9. Willems GM, Visser MP, Krill MTA, Hermens WTh. Quantitative analysis of plasma enzyme levels based upon simultaneous determination of different enzymes. Cardiovase Res 1982; 16:120-131. 
10. Willems GM, Van der Veen FH, Huysmans HA, Flameng W, De Meyere R, Van der Laarse A, Van der Vusse GJ, Hermens WTh. Enzymatic assessment of myocardial necrosis after cardiac surgery: differentiation from skeletal muscle damage, hemolysis and liver injury. Am Heart J 1985; 109:1243-1252.

11. Hermens WTh, Willems GM, Visser MP. Quantification of circulating proteins. The Hague: Martinus Nijhoff Publi, 1982.

12. Willems GM, Assessment of myocardial injury. Thesis, Maastricht, 1985.

13. Sakakibara S, Shiomi K, Kobayashi S, Ikeda T, Irrai S, Kagamiyama H. A convenient and sensitive method for the determination of serum aspartate aminotransferase isozymes after electropheresis. Clin Chim Acta 1983; 133:119123.

14. Van der Helm HJ, A simplified method of demonstrating lactic dehydrogenase isoenzymes in serum. Clin Chim Acta 1962; 7:124-128.

15. De Rosa G, Swick RW. Metabolic implications of the distribution of the alanine aminotransferase isoenzymes. J Biol Chem 1975; 250:7961-7967.

16. Ruscak M, Orlicky J, Zubor V. Isoelectric focussing of the alanine aminotransferase isoenzymes from the brain, liver and kidney. Comp Biochem Physiol 1982; 71B:141144.

17. Wisse E, de Zanger RB, Charels K, Van der Smissen P, McCuskey RS. The liver sieve: considerations concerning the structure and function of endothelial fenestrae, the sinusoidal wall and the space of Disse. Hepatology 1985; 5:683-692.

18. Lindena L, Küpper W, Trautschold I. Catalytic enzyme activity concentration in thoracic duct, liver, and intestinal lymph of the dog, the rabbit, the rat and the mouse. J Clin Chem Clin Biochem 1986; 24:19-33.

19. Engeset A, Aas M, Olszewsky W, Sokolowsky J. Time of exchange of 131I-labeled albumin between plasma and peripheral lymph in man. Lymphology 1979; 12:7780.

20. Schmidt E, Schmidt FW, Herfarth C, Opitz K, Vogell W. Analyse des bei Perfusion unter Hypoxie entstehenden extrazellulären Enzymmusters. III. Mitteillung über Studien zum Austritt von Zellenzymen am Modell der isolierten perfundierten Rattenleber. Enzymol biol clin 1966; 7:185-193.

21. Hermens WTh, Willems GM, Davids HA, Hollaar L, van der Laarse A. Enzymatic assessment of myocardial injury after infarction or cardiac surgery. Is isoenzyme analysis required? Clin Chim Acta 1986; 156:235-246. 
और

मिक्ष क्ष

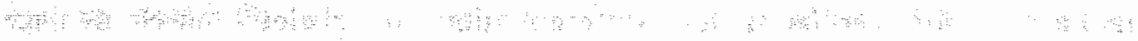

Am, क्ष

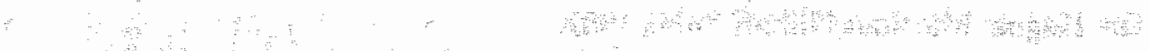

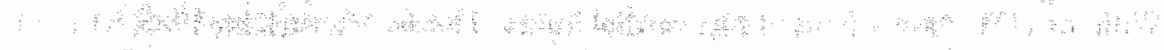
-

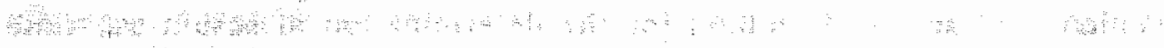

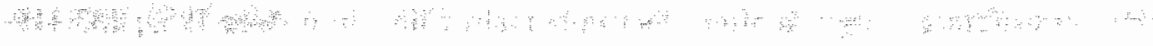
: a

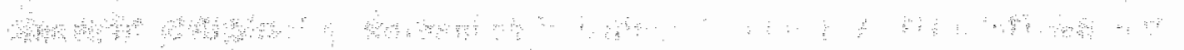

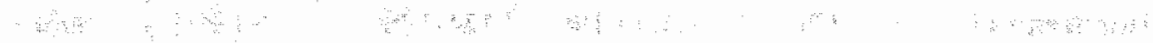

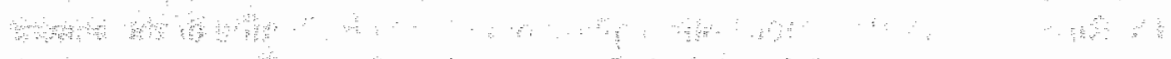
a

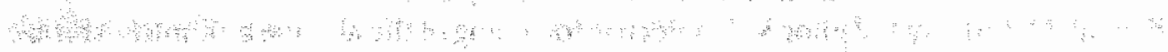

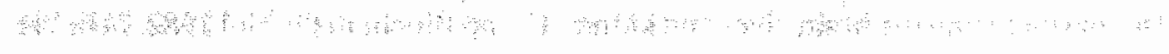

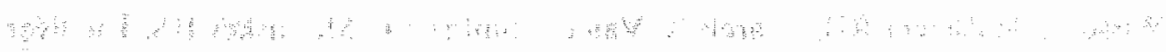

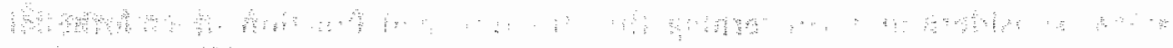

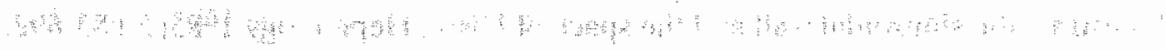

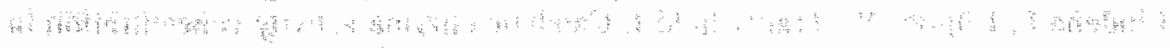

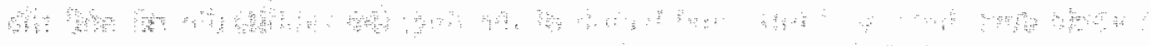
a

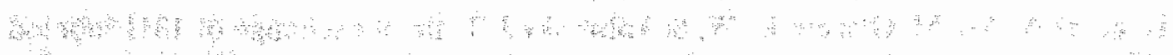

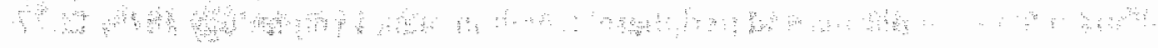

सम

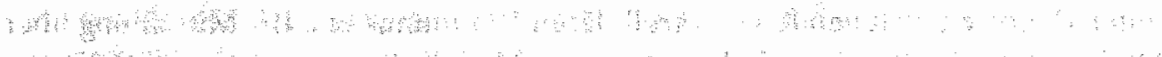

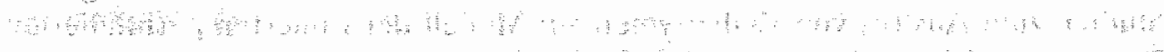

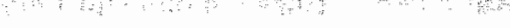

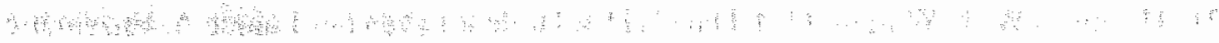

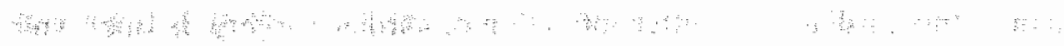

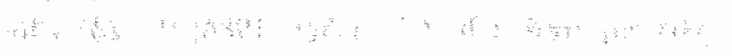




\section{CHAPTER 4}

\section{Mitochondrial disruption as a primary event in acute liver necrosis}

\section{INTRODUCTION}

The activities of mitochondrial hepatic enzymes in plasma are usually only moderately elevated in various forms of liver disease. For instance, plasma activities of the mitochondrial enzyme glutamate dehydrogenase (GLDH) are often lower than the activities of the cytosolic enzyme alanine aminotransferase (ALT) even although the GLDH activity in liver tissue is about ten times higher than the ALT activity. Also, the plasma enzyme activities of mitochondrial aspartate aminotransferase (mAST) are usually only a small fraction of total aspartate aminotransferase activities, in spite of the fact that the liver contains about four times more mAST than cytosolic AST (CAST) [ 1 and Chapter 3 of this thesis]. Due to this incomplete release, mitochondrial enzymes are considered as less sensitive diagnostic markers than cytosolic enzymes, especially in chronic liver disease [2], despite the common belief that their release is a sign of severe injury [3]. Several mechanisms could be responsible for this phenomenon of incomplete mitochondrial enzyme release, such as integral destruction of mitochondria due to phagocytosis, lack of liberation of enzymes from mitochondrial structures, rapid inactivation of enzymes detached from the mitochondrial matrix or rapid elimination from plasma of mitochondrial enzymes that reached the circulation.

Apart from uncertainties about the recovery of mitochondrial enzymes in plasma, there also conflicting data in the literature about the time course of mitochondrial enzyme release, in particular about the existence of a delay between the release of cytosolic and mitochondrial enzymes. Clinical studies have shown that mitochondrial enzymes are detected in plasma during the early phase of acute liver necrosis $[4,5]$, but recent experimental studies on liver ischemila th the rat demonstrate a much delayed release compared to cytosolic enzymes [6,7]. This would indicate an analogy with ischemic muscle necrosis, for it has been shown that the release of mitochondrial enzymes after acute myocardial infarction is a late phenomenon $[8,9]$. In a recent study we selected patients with acute liver necrosis who were hospitalized early after the acute event. It was found that the first few plasma samples obtained from these patients frequently contained high fraction of mAST, of the order of $50 \%$ of total AST activity (Chapter 3). In the present study these data are compared with the plasma activities of two other mitochondrial enzymes, GLDH and ornithine carbamyl transferase (OCT), and used to estimate the fractional catabolic rate (FCR) constants of these enzymes for 
their elimination from plasma. Using the values of FCR thus obtained, cumulative enzyme release in plasma is calculated and the recovery as well as the time course of release of these enzymes are compared with those of cytosolic enzymes like cAST, ALT and LDH.

\section{PATIENTS AND METHODS}

\section{Selection of patients}

Patients with a short-lasting period of acute liver necrosis were selected as described in Chapter 3. They either suffered from various forms of shock (patients no. $2,4,5,7,8$ and 9 in Table 1), or acute biliary obstruction (patients no. 1,3,6 in Table 1) and were hospitalized early enough to obtain part of the upstroke of plasma enzyme activities. When informed consent was acquired from eligible candidates, venous blood samples of $10 \mathrm{ml}$ of blood were obtained approximately every 12 hours. Clotting was prevented with heparin and after centrifugation plasma samples were stored at $-20^{\circ} \mathrm{C}$

\section{Determination of enzyme activities}

Enzymes activities of aspartate aminotransferase (AST; EC 2.6.1.1), alanine aminotransferase (ALT; EC 2.6.1.2), lactate dehydrogenase (LDH; EC 1.1.1.27), and glutamate dehydrogenase (GLDH; EC 1,4.1.3) were determined spectrophotometrically using commercial test kits (Boehringer Mannheim). Measurements were performed in a centrifugal analyzer (Cobas Bio, Hoffman- LaRoche) at $25^{\circ} \mathrm{C}$ and expressed in micromoles of substrate converted per minute per liter of plasma (U/1). Ornithine carbamyl transferase (OCT; EC 2.1.3.3) was determined as described in Chapter 2. Isoenzymes of AST were separated by electrophoresis [10] on agarose gels (Beckman, Paragon LD or SPE).

\section{Estimation of fractional catabolic rate constants}

The estimation method is described in Chapter 3, It is based on the analysis of the plasma time-activity curves of two simultaneously released enzymes. A possible time delay between the release of both enzymes would invalidate the method [11] and combinations of cytosolic and mitochondrial enzymes were therefore not considered. First the combination of GLDH and the much more rapid catabolized mAST was analyzed. Using the values of FCR(mAST) thus obtained, the combination of OCT and mAST was then analyzed in order to obtain FCR(OCT). Estimations were based on the first 100 hours of the time-activity curves.

\section{Assessment of cumulative enzyme release}

Cumulative release of enzyme activity per liter of plasma from zero time up to time $t$ was calculated from the plasma activities $C(t)$ using:

$$
Q(t)=C(t)+T E R \cdot \exp (-E R R \cdot t) \int_{0}^{t} \exp (E R R \cdot t) C(t) d t+F C R \cdot \int_{0}^{t} C(t) d t
$$


Values for the constants used in the calculations, were FCR(LDH) $=0.13 \mathrm{~h}^{-1}$, FCR (CAST) $=0.088 \mathrm{~h}^{-1}$, FCR $($ ALT $)=0.034 \mathrm{~h}^{-1}$, TER $=0.014 \mathrm{~h}^{-1}$ and ERR $=0.018$ $\mathrm{h}^{-1}$ (Chapter 3).

\section{Expression of cumulative release in gram-equivalents per liter}

Cumulative enzyme release was expressed in gram-equivalents of healthy liver per liter. To this end, values of $Q(t)$ were divided by the mean activities in control livers $(\mathrm{n}=8)$ expressed per gram of wet weight i.e., $42 \mathrm{U} / \mathrm{g}$ for mAST, $117 \mathrm{U} / \mathrm{g}$ for GLDH, 0.3 $\mathrm{U} / \mathrm{g}$ for OCT, $17 \mathrm{U} / \mathrm{g}$ for ALT, $16 \mathrm{U} / \mathrm{g}$ for cAST and $117 \mathrm{U} / \mathrm{g}$ for LDH (Chapter 3 ).

\section{RESULTS}

Figure 1 presents the plasma time-activity curves of cytosolic and mitochondrial enzymes in 9 patients who suffered from a short period of acute liver injury. In the period starting $\mathbf{4 8}$ hours after the acute event these curves conform to the usually observed pattern with relatively low mAST activities. However, during the first 24 hours there is a considerable release of mAST with plasma activities of about 30-50\% of total AST activity. Figure 1 also shows the absence of a delay between the release of cytosolic and mitochondrial enzymes.

Table 1 presents the results of the estimation procedure. Apart from the values of FCR, one also obtains an estimate of the ratio of released activities $r$ (Chapter 3). It follows from this table that the activities of GLDH, mAST and OCT are released in

Table 1, Estimated values of the Fractional Catabolic Rate constants(FCR) foir the mitochondrial enzymes mAST, GLDH and OCT, expressed in (hours) ${ }^{-1}$. The ratios of released activities r(GLDH/mAST) and $\mathrm{r}(\mathrm{OCT} / \mathrm{mAST})$ are also given.

\begin{tabular}{lccccc}
\hline Patient & FCR(mAST) & FCR(GLDH) & FCR(OCT) & r(GLDH/mAST) & r(mAST/OCT) \\
\hline 1 & 0.042 & 0.030 & 0.023 & 2.1 & 4 \\
2 & 0.210 & 0.083 & 0.053 & 2.2 & 34 \\
3 & 0.293 & 0.155 & 0.064 & 2.4 & 57 \\
4 & 0.118 & 0.030 & 0.017 & 1.5 & 16 \\
5 & 0.181 & 0.060 & 0.083 & 0.5 & 126 \\
6 & 0.272 & 0.107 & 0.153 & 1.3 & 21 \\
7 & 0.176 & 0.105 & 0.098 & 0.4 & 75 \\
8 & 0.117 & 0.083 & 0.086 & 1.7 & 21 \\
9 & 0.304 & 0.104 & 0.077 & 3.2 & 130 \\
& & & & & \\
mean & 0.190 & 0.084 & 0.073 & 1.7 & 54 \\
SD & 0.089 & 0.040 & 0.041 & 0.9 & 47 \\
SE & 0.030 & 0.013 & 0.014 & 0.3 & 16 \\
\hline
\end{tabular}



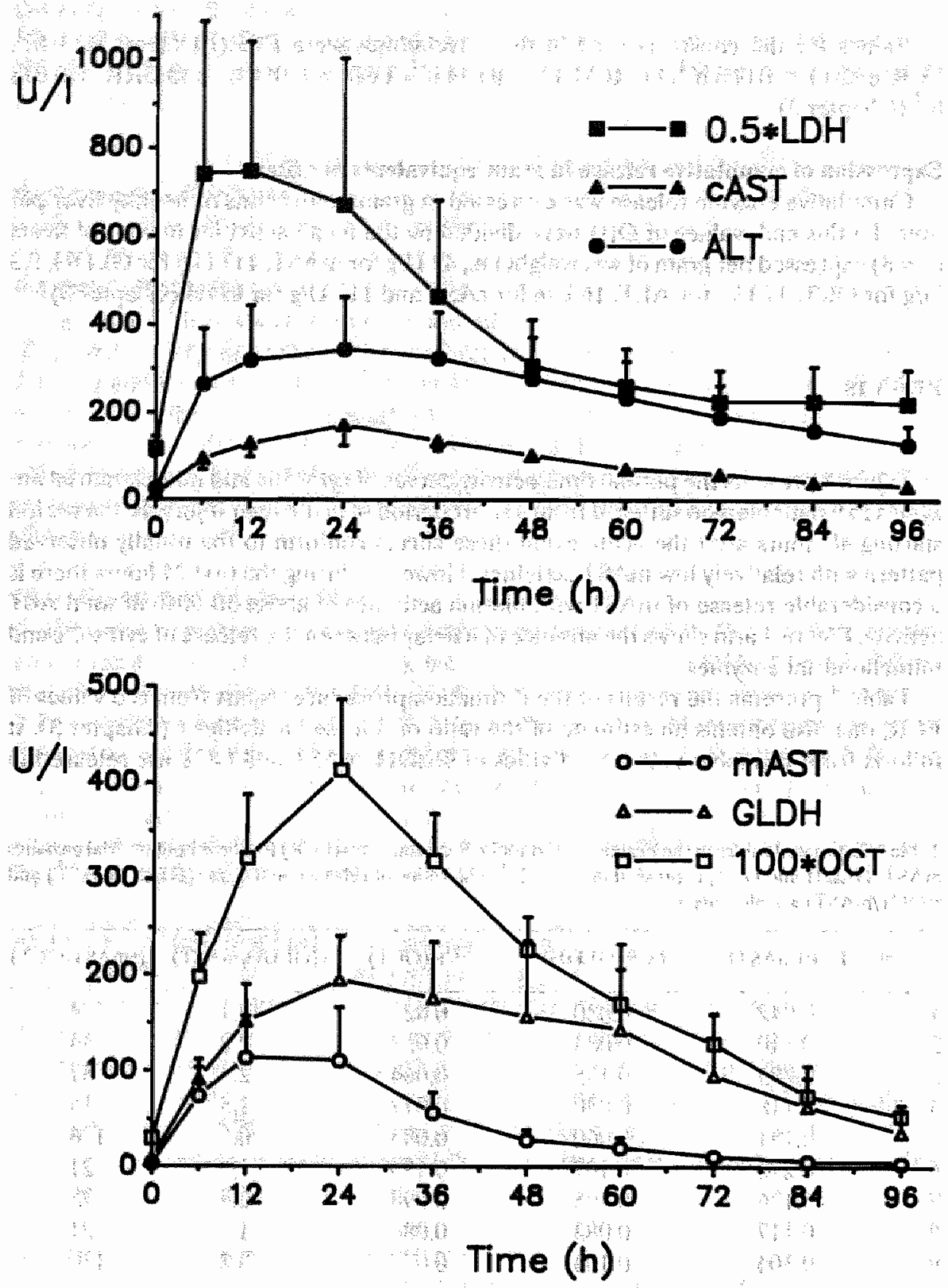

Figure 1 shows the mean time-activity curves for the cytosolic (top) and mitochondrial (bottom) enzymes. in 9 patients with acute liver necrosis. Standard errors (SEM) are indicated. 
proportions of 1.7:1:0.02. As the proportions of these enzymes in liver tissue are 2.8:1:0.01 (cf. Methods section), it follows from these data that GLDH is recovered in plasma less completely than mAST, while OCT is recovered more completely than mAST (cf. Figure 2). Table 1 shows that mAST is eliminated rapidly from plasma (19\% per hour), i.e. more than twice as fast as cAST ( $8.8 \%$ per hour; cf. Methods section). The considerable variation observed in the values of FCR $(\mathrm{sd}=50 \%)$ is mainly caused by experimental scatter in plasma enzymes activities and the relatively scarce sample schedule [12]. Electrophoretic separation of isoenzyme adds to further experimental scatter and the same is true for the relatively complicated two-stage OCT assay with the long incubation period (Chapter 2). Considering these circumstances, the seatter in the values presented in Table 1 is within the expected range.

Figure 2 presents cumulative release of enzymes, calculated as explained in the Methods section and expressed in gram-equivalents of liver tissue per liter of plasma. The estimates of the extent of injury obtained from the three cytosolic enzymes LDH, ALT and CAST are equivalent to 50-70 geq/l. Considering the standard errors these estimates are not significantly different and one may conclude that these cytosolic enzymes are released in proportion to their activities in liver tissue (Chapter 3). This is also true for OCT, but not for MAST and GLDH. The latter two enzymes are only recovered for about $30 \%$ and $15 \%$.

Figure 3 shows only a weak correlation between the estimates of injury based on cAST and mAST.

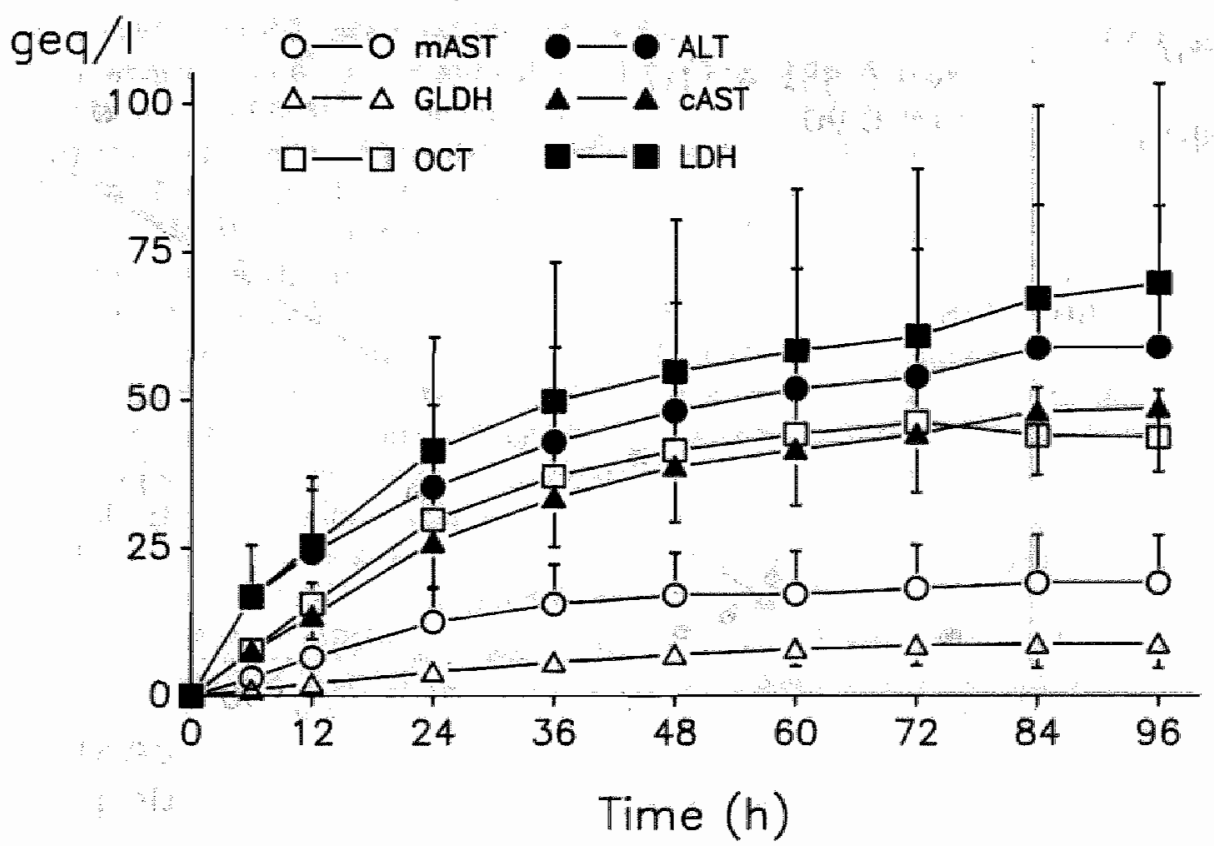

Figure 2 shows the cumulative release of $\mathrm{LDH}, \mathrm{ALT}$, CAST, OCT; mAST and LDH in 9 patients with acute liver necrosis. Standard errors (SEM) are indicated, 


\section{Discussion}

The plasma mAST activities observed in the present study during the first 24 hours after an acute episode of liver necrosis, are higher than usually reported in the literature [3]. A variety of different techniques has been used for the separation of AST isoforms, including ion-exchange chromatography, electrophoresis, immuno-inhibition and various kinetic methods. This variability could explain some điscrepancies, but it is very unlikely that the electrophoretic procedure used in the present study would cause systematic overestimation of the mAST fraction, because the value of $72 \%$ obtained for the mAST fraction in control livers (Chapter 3 ) was determined by the same method and this value is lower than the value of $81 \%$ found in a comparison of different methods [1]. A more reasonable explanation seems to be the fact that the patients in the present study were selected for their early hospitalization, because the estimation procedure for FCR-values requires the initial upstroke of plasma enzyme activities (Chapter 3). Such patients are relatively rare and it follows from Figure 1 that plasma mAST activities indeed rapidly decline after $36-48$ hours. A less stringent selection of patients would probably have resulted in a majority of patients hospitalized after this period and lacking the initial mitochondrial release. The present paper also

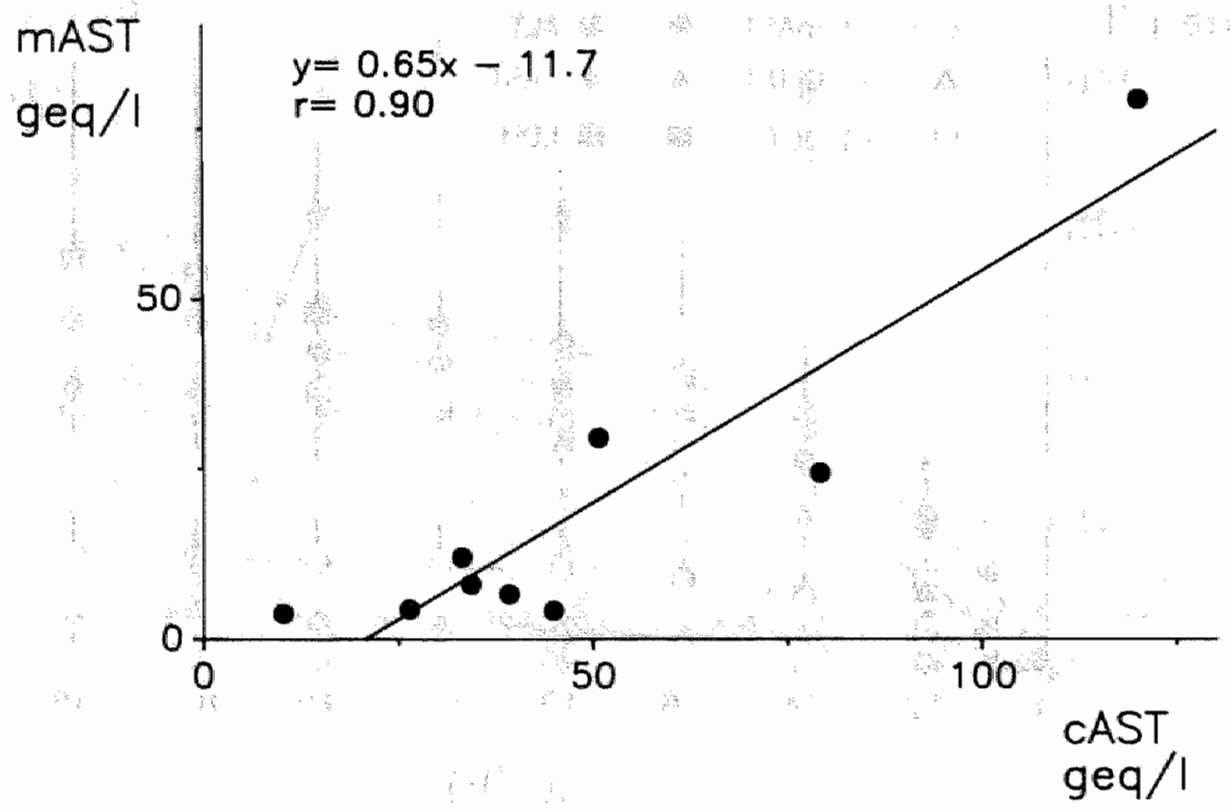

Figure 3 is a scatter plot of the cumulative release of CAST and mAST during the first 96 hours after a period of acute liver necrosis. Values are expressed in gram-equivalents of liver tissue per liter of plasma. 
confirms an earlier study [5] on patients with acute right-side heart faIture, a condition that was also present in patients 8 and 9 of Table 1. In this study high initul walues of GLDH were observed which reached their peak values simultareously wit AST. Howewer, OCT and mAST were not determined.

There are few data in the literature that can be compared to the values of FCR. presented in Table 1. A mean half-life time of about 16 hours was reported for the disappearance of GLDH from plasma in 6 patients with various forms of acute liver injury [13]. This value corresponds to an apparent fractional disappearance rate constant $\mathrm{kd}=\ln 2 / 16=0.043 \mathrm{~h}^{-1}$, i.e. a twofold slower elimination rate than would be observed if catabolism were the only determining factor (FCR(GLDH) $=0.084 \mathrm{~h}^{-1}$; $\mathrm{cf}$. Table 1). As explained in Chapter 3 , the value of $\mathrm{k}_{\mathrm{d}}$ must indeed be lower than FCR becasse of extravascular return of activity to plasma during the elimination phase and because of some residual, tailing release of enzymes from the liver. The disappearance rates of OCT from plasma has not been measured systematically in patients with liver disease. The half-life time of mAST has been reported to be about 6 hours [14], corresponding to a fractional disappearance constant of $k_{d}=0.12 h^{-1}$, lower than the FCR(mAST) calculated in this study (cf. Table 1). The faster elimination of mAST compared to cAST has been confirmed in various species $[7,15,16]$. This phenomenon has been related to the tendency of mitochondrial enzymes to aggregate with macroglobulins [17].

It is interesting to note from Figure 2 that OCT is recovered in plasma as complete as the cytosolic enzymes. It seems as if the total mitochondrial OCT pool is liberated together with the cytoplasmic content of the damaged hepatocyte. For mAST it has been shown in cardiac myocytes that only about $30 \%$ of the total activity is released after reoxygenation of anoxic cell cultures [18]. This observation was related to different locations of mAST in the mitochondrion [19]. The limited release of GLDH is a puzzling phenomenon. A circulating inhibitor of this enzyme has been demonstrated in Reye's disease [20]. It is tempting to speculate that some, as yet unidentified, inhibitor of GLDH is also present in normal plasma. The preferential release of mAST, compared to GLDH, has also been observed after acute hepatitis [3].

The present study shows that mitochondrial enzymes are released as soon as the hepatocyte starts to loose cytosolic encymes. This indicates that mitochondrial disny-

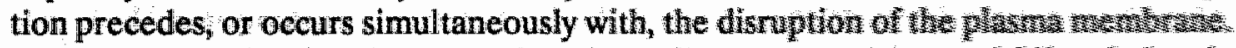
This contrasts with the results obtained in studies on temporary partis litwer

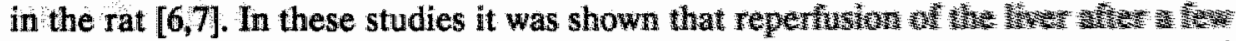
hours of ischemia results in a pattern of enzyme release with sastis the mitochondrial fraction compared to the cytosolic one: Martow

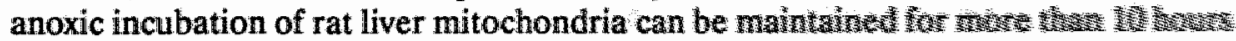

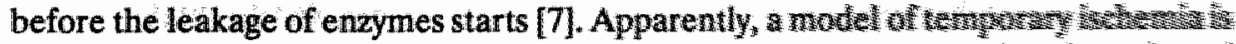
ill-suited to describe liver cell necrosis after shock or acute chulestadis

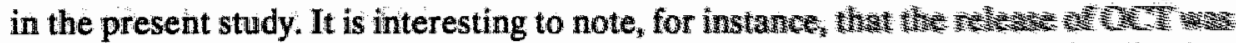

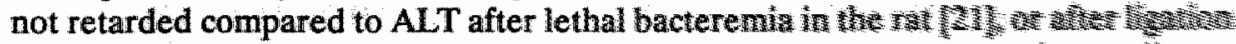

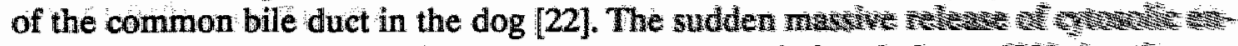
zymes observed after reperfusion of the temporary isthemic hesat hat called reperfusion injury, has probably also occurred in the mentwathe may be the result of an unphysiological selective destriction of the nt: 


\section{REFERENCES}

1. Rej R. Aspartate aminotransferase activity and isoenzyme proportions in human Hiver tissue Clin Chem 1978,24:1971-1979.

2. Jung K, Pergande M, Rej R, Schreiber G, Schimmelpfennig W. Mitochondrial enzymes in human serum: comparative determinations of glutamate dehydrogenase and mitochondrial aspartate aminotransferase in healthy persons and patients with chronic liver diseases. Clin Chem 1986;31:239-243.

3. Schmidt E, Schmidt FW. Fundamentals and evaluation of enzyme patterns in serum. In. Popper H, Schaffner F, eds. Progress in liver disease, vol. VII. New York, Grune \& Stratton, 1982,411-428.

4. Ideo G, De Franchis R, Bellobuono A, Sforzini S, Dioguardi N. Serum cytosolic/mitochondrial enzyme ratio: a tool for the estimation of the severity of acute hepatitis. Z Klin Chem Klin Bilochem 1972;10:74-76.

5. Guder WG, Habicht A, Kleiszl J, Schmidt U, Wieland OH The diagnostic significance of liver cell inhomogenenity: serum enzymes in patients with central liver necrosis and the distribution of glutamate dehydrogenase in normial humanliver. Z Klin Chem Klin Biochem 1975;13;311-318.

6. Frederiks WM, Marx F. Changes in the cytoplasmic and mitochondrial enzymes in rat liver after ischemia followed by reperfusion. Exp Mol Path 1987;47:291-299.

7. Nishimura T, Yoshida Y, Watanabe F, Koseki M, Nishida T, Tagawa K, Kawashima Y.Blood level of mitochondrial aspartate aminotransferase as an indicator of the extent of ischemic necrosis of the rat liver. Hepatology 1986;6:701-707.

8. Smith AF, Wong PC-P, Oliver MF. Release of mitochondrial enzymes in acute myocardial infarction. J Mol Med 1977;2:265-269.

9. Hermens WTh, Willems GM, Davids HA, Hollaar L, van der Laarse A. Enzymatic assessment of myocardial injury after infarction or cardiac surgery. Is isoenzyme analysis required Clin Chim Acta $1986,156: 235-246$.

10. Sakakibara S, Shiomi K, Kobayashi S, Ikeda T, Irrai S, Kagamiyama H. A convenient and sensitive method for the determination of serum aspartate aminotransferase isozymes after electropheresis. Clin Chim Acta 1983; 133:119123.

11. Hermens WTh, Willems GM, Visser MP. Quantification of circulating proteins. The Hague: Martinus Nijhoff Publ, 1982.

12. Willems GM, Assessment of myocardial injury. Thesis, Maastricht, 1985.

13. Donath $R$. Die Habwertszeit der Elimination der Serumglutamatdehydrogenase und deren Einflusz auf die Anwendung des GPT/GLDH-Quotienten für die Diagnose des akuten Verschluszikterus. Dtsch Ges wesen 1971;26:2319-2323.

14. Gruber W. Bestimmung von Enzymaktivitäten in vivo. J Mond Pharm 1969;12:203228. 
15. Fleisher GA, Wakim KG. The fate of enzyme in body fluids - an experimental study. III. Disappearance rates of glutamic-oxalacetic transaminase II under various conditions. J Lab Clin Med 1963;61:98-106.

16. Bär U, Ohlendorff S. Studien zur Enzymelimination. Klin Wschr 1970; 48:776-779.

17. Boyde TRC. Interaction between alpha2-macroglobuline and cationic aspartate aminotransferase. Biochem J 1969;111:59-65.

18. Van der Laarse A, Davids HA, Hollaar L, Hermens WTh. Enhanced release of mitochondrial aspartate aminotransferase (mAST) from anoxic heart cell cultures during reoxygenation. Comparison to plasma mAST levels in patients after acute myocardial infarction and after cardiac surgery. Cardiovas Res 1981;15:11-20.

19. Gil M, Cascante M, Cortes A, Bozal J. Intramitochondrial location and some characteristics of chicken liver aspartate aminotransferase. Int $\mathrm{J}$ Biochem 1987; 19:355-363.

20. Holt JF, Arvan DA, Mayer TK. Masking of enzyme inhibitor of raised serum glutamate dehydrogenase activity in Reye's syndrome. Lancet 1983;ii:4-7.

21. Sato T, Tanaka J, Kono Y, Jones RT, Cowley A, Trump BF. Hepatic cellular injury following lethal Escherichia coli bacteremia in rats. Lab Invest 1982;47:304-310.

22. Reichard $\mathrm{H}$. Ornithine carbamyl transferase in dog serum on intravenous injection of enzyme, choledochus ligation, and tetrachloride poisoning. J Lab Clin Med 1959;53:417-425.

23. Hearse DJ, Humphrey SM, Chain EB. Abrupt reoxygenation of the anoxic potassium-arrested, perfused rat heart; a study of myocardial enzyme release. $\mathrm{J}$ Mol Cell Cardiol 1973;5:395-407. 
Bमत:

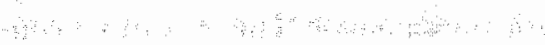

$\therefore$

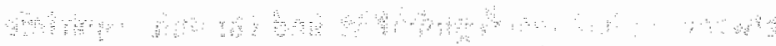

a $\quad$ a

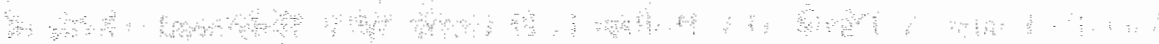

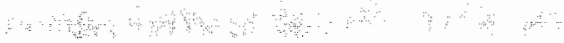

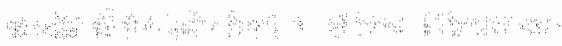

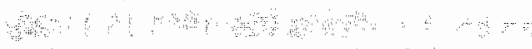

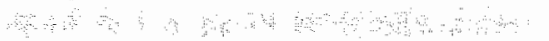
मा :

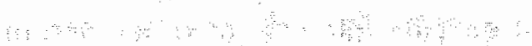

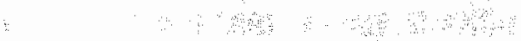

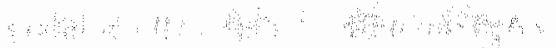

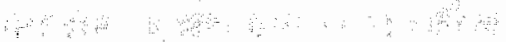

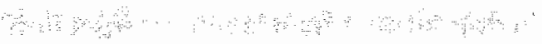

की

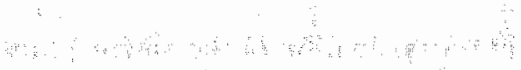

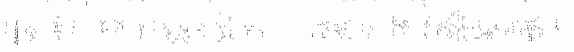

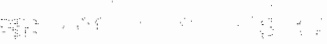




\section{CHAPTER 5}

\section{Cumulative Enzyme Release in Cholestasis}

\section{INTRODUCTION}

In cholestasis two distinct mechanisms lead to an increase in membrane-bound enzymes in plasma. First, the liver reacts with de novo synthesis of tissue membranebound enzymes [1]. Second, the detergent action of accumulated bile acids in the liver leads to solubilization of membrane-bound enzymes [2,3].

This process of induction and solubilization of membrane-bound enzymes may occur with minimal or no cytosolic enzyme release at all. Apparently, in this state, bile acids may affect membranes but do not cause membrane disruption. However, cholestasis may also lead to considerable cytosolic enzyme loss, in which case, the liver cell apparently has lost its integrity. In comparison with aspartate aminotransferase (AST) and alanine aminotransferase (ALT), the release of lactate dehydrogenase (LDH) in cholestatic injury has been reported to be low [4]. In cholestatic livers a severalfold increase in tissue alkaline phosphatase (AP) and gamma-glutamyltransferase (GGT) activity is observed [5-7]. The activity of LDH per gram liver tissue is decreased [8,9] while the activity of AST and ALT is unchanged [10].

Several questions are raised by these observations. First of all, if there exists some degree of detergent action above which the liver cell becomes permeable one would expect cytosolic enzyme release only in cases with hilgh plasma activities of GGT and AP. In contrast, if the induction of membrane-bound enzymes decreases when liver cells become permeable an inverse relationship could be expected. If cumulative enzyme release could be calculated in this form of liver injury, it may be decided if tissue enzyme changes are reflected in the enzyme pattern in plasma.

To this end, the FCR values of the membrane-bound enzymes AP and GGT are estimated in this study and by means of the values of the FCR values of cytosolic liver enzymes estimated earlier (Chapter 3 ), the aspects outlined above are studied. 


\section{METHODs}

\section{Patient selection}

Patients with increased plasma activities of AP and GGT entered the study if either choledocholithiasis was confirmed at surgery or if enlargement of the extrahepatic bile ducts with or without gall stones was demonstrated ultrasonographically. Patients entered in one of four groups. Nine patients with undisturbed plasma disappearance curves of AP and GGT, following a period of elevation of plasma activities were selected for the estimation of values of FCR(AP) and FCR(GGT) (cf. below). If the history taken on admission revealed a cholestatic episode shorter than one week, as judged by pain and/or other signs of cholestasis, patients were considered to have 'acute ${ }^{x}$ biliary obstruction. Biliary obstruction of longer duration was classified as 'chronic' biliary obstruction. The fourth group consisted of nine patients with bile obstruction secondary to a malignancy (pancreas carcinoma, Klatskin tumor or carcinoma of the papilla of Vater). Patients with ultrasonographical evidence of liver metastases were excluded.

\section{Enzyme determinations}

Venous blood samples were obtained at 12 to 24 hour intervals. Following collection samples were centrifuged and plasma stored at $-20^{\circ} \mathrm{C}$.

Plasma enzyme activities of AST (EC 2.6.1.1.), ALT (EC 2.6.1.2.), LDH (EC 1.1.1.27), AP (EC 3.1.3.1.) and GGT (EC 23.2.2.) were determined using a centrifugal analyzer (Cobas Bio - Hoffman La Roche). Commercially available kits were used (Boehringer no. 258784 for AST; no. 258822 for ALT; no. 620092 for $\mathrm{LDH}$; and no. 543080 for GGT; AP from Merck no. 3344). Isoenzymes of AST were separated electrophoretically as described in [12] and it was verified that more than $90 \%$ of total plasma AST activity consisted of the cytosolic subfraction (cAST). All activities are expressed as micromoles of substrate converted per minute per liter (U/l). Activities were assessed at $25^{\circ} \mathrm{C}$.

Liver homogenates were prepared according to the method described in [11].

\section{Estimation of the Fractional Catabolic Rate Constants}

Values of FCR(AP) and FCR(GGT) were estimated from the apparent disappearance rates from plasma. Because both enzymes are eliminated very slowly, the apparent disappearance rate could be measured between 96 and 192 hours after the start of the elimination phase. The true values of FCR are higher than the apparent disappearance constants because there is extravascular return of enzyme activity to plasma during the elimination phase. Values of $k_{d}$ were therefore corrected as described in [13]. Fixed values for the exchange parameters TER $=0.014 \mathrm{~h}^{-1}$, and ERR $=0.018 \mathrm{~h}^{-1}$ were used. 


\section{Assessment of Cumulative Enzyme Release}

Cumulative release of enzyme activity per liter of plasma from zero time up to time $t$ was calculated from the plasma activities $C(t)$ using:

$$
Q(t)=C(t)+T E R \cdot \exp (-E R R \cdot t) \int_{0}^{t} \exp (E R R \cdot t) C(t) d t+F C R \cdot \int_{0}^{t} C(t) d t
$$

Values for the constants used in the calculations, were FCR(LDH) $=0.13 \mathrm{~h}^{-1}$, FCR $($ AST $)=0.088 \mathrm{~h}^{-1}, \mathrm{FCR}(\mathrm{ALT})=0.034 \mathrm{~h}^{-1}, \mathrm{TER}=0.014 \mathrm{~h}^{-1}$ and ERR $=0.018$ $\mathrm{h}^{-1}$ [11]. Cumulative release was expressed in gram-equivalents of healthy liver per liter. To this end, values of $Q(t)$ were divided by the mean activities in control livers $(\mathrm{n}=8)$ expressed per gram of wet weight i.e., $12 \mathrm{U} / \mathrm{g}$ for AP, $6 \mathrm{U} / \mathrm{g}$ for GGT, $16 \mathrm{U} / \mathrm{g}$ for cAST, $17 \mathrm{U} / \mathrm{g}$ for ALT and $117 \mathrm{U} / \mathrm{g}$ for $\mathrm{LDH}[11]$.

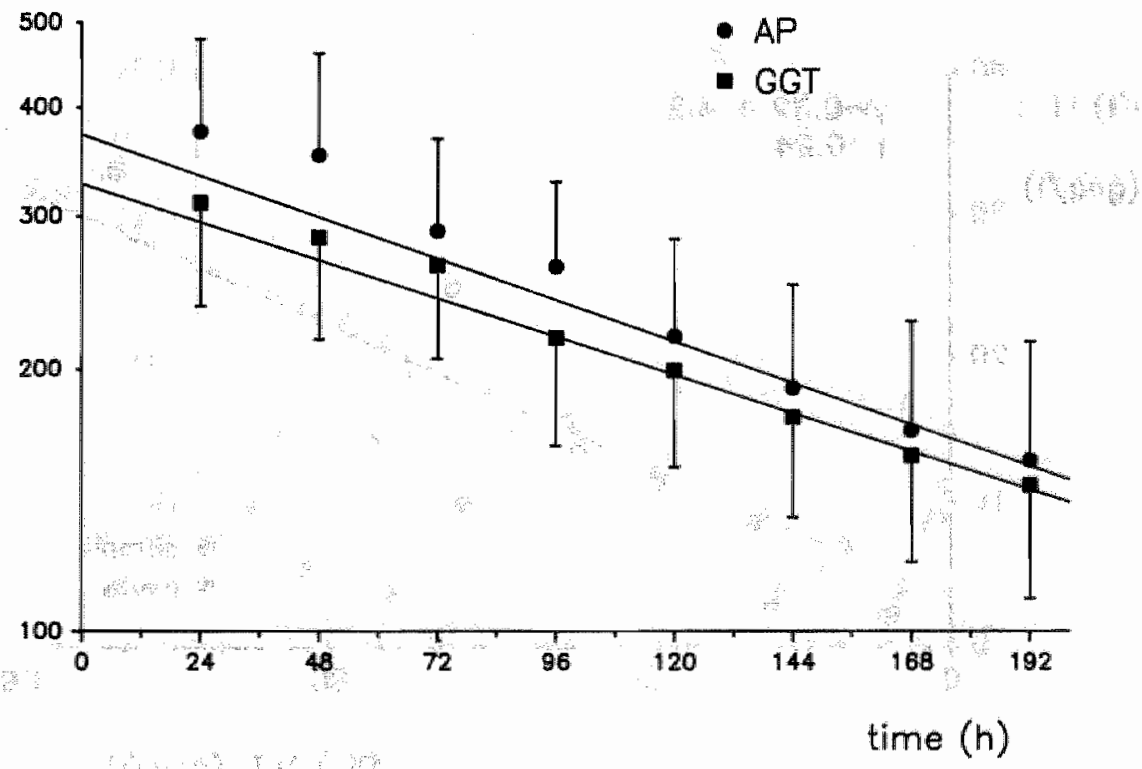

Figure 1. Logarithmic plot of the time mean plasma enzyme activities of alkaline phosphatase (AP) and gamma-glutamyl transferase (GGT) corrected for the normal steady state plasma activities $(\mathrm{n}=9$, SEM is indicated). The best: fitting straight line was estimated by means of linear regression for the last four data points of both curves. The slope of this line represents the mean $k_{d}$ of both enzymes. 

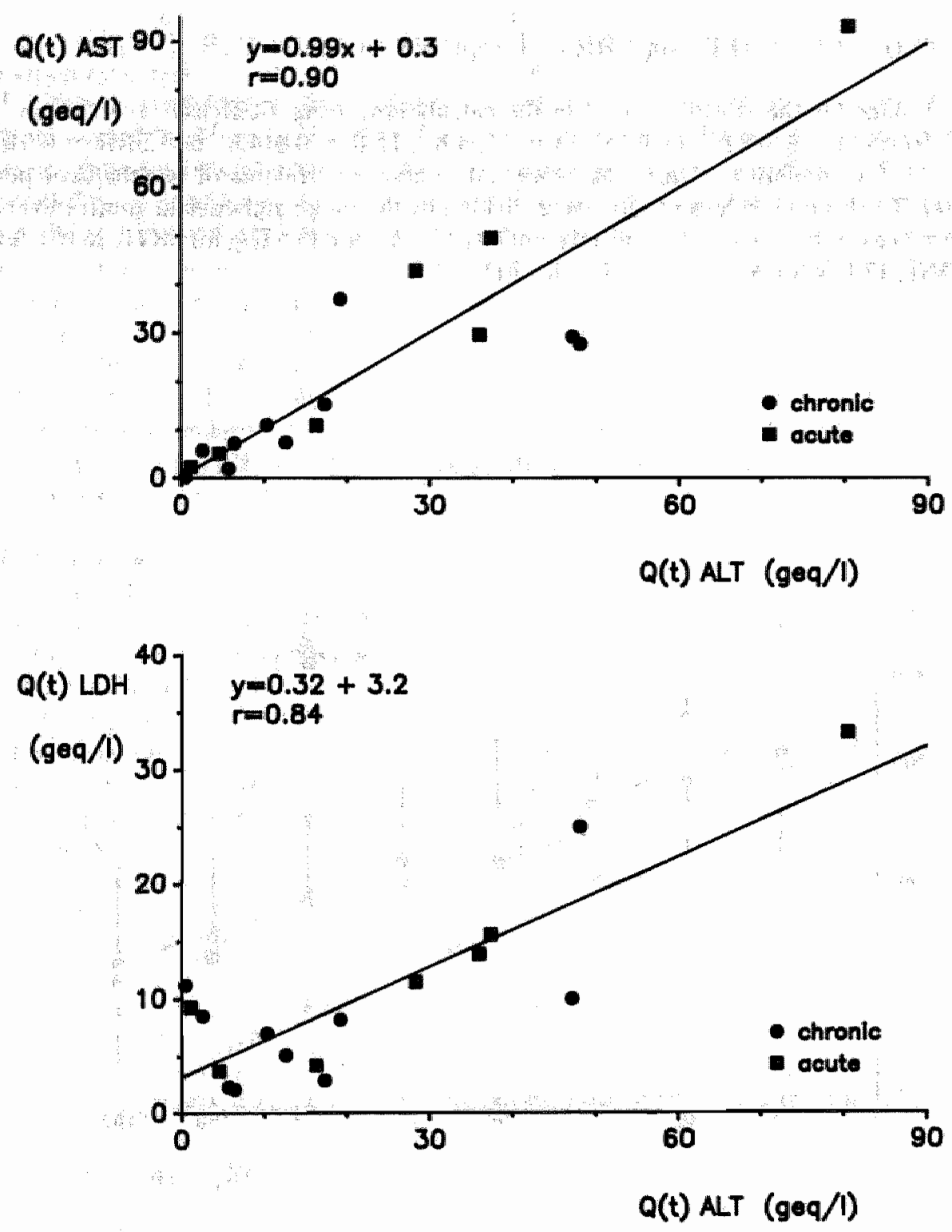

Figure 2. Scatter plot for cumulative enzyme release of ALT and AST (top) and of ALT and LDH (bottom) . Cumulative enzyme activity per liter of plasma is divided by the activity per gram wet weight of liver (geq/). The best fitting straight line is calculated by linear regression. 


\section{RESULTS}

Figure 1 presents a logarithmic plot of the curves of AP and GGT in patients of group one with undisturbed elimination after an episode of biliary obstruction. Normal values of $C_{s}(A P)=96 \pm 5 \mathrm{U} / 1$ and $C_{s}(G G T)=16 \pm 2 \mathrm{U} / 1$ were subtracted from the plasma activities. The fractional apparent disappearance rate constants, measured in the period after 96 hours, were $k_{d}=0.0086 \pm 0.0019 \mathrm{~h}^{-1}$ for AP and $k_{d}=0.0073 \pm$ $0.0015 \mathrm{~h}^{-1}$ for GGT (mean $\pm \mathrm{SEM}, \mathrm{n}=9$ ). By chosing such a long period after the acute event, it can be assumed that the hepatic release of these enzymes has been completely terminated and that the extravascular compartment is saturated. The disappearance curve then reflects the combined effects of elimination from plasma, with a fractional catabolic rate constant FCR, and extravascular return of activity to plasma. As a result, the values of $k_{d}$ are lower than the values of FCR. Knowing the transcapillary escape rate constant TER and the extravascular return rate ERR, however, values of FCR can be calculated from the values of $k_{d}$ obtained from the terminal part of the disappearance curve as explained in ref [13], page 103. Application of this correction, using

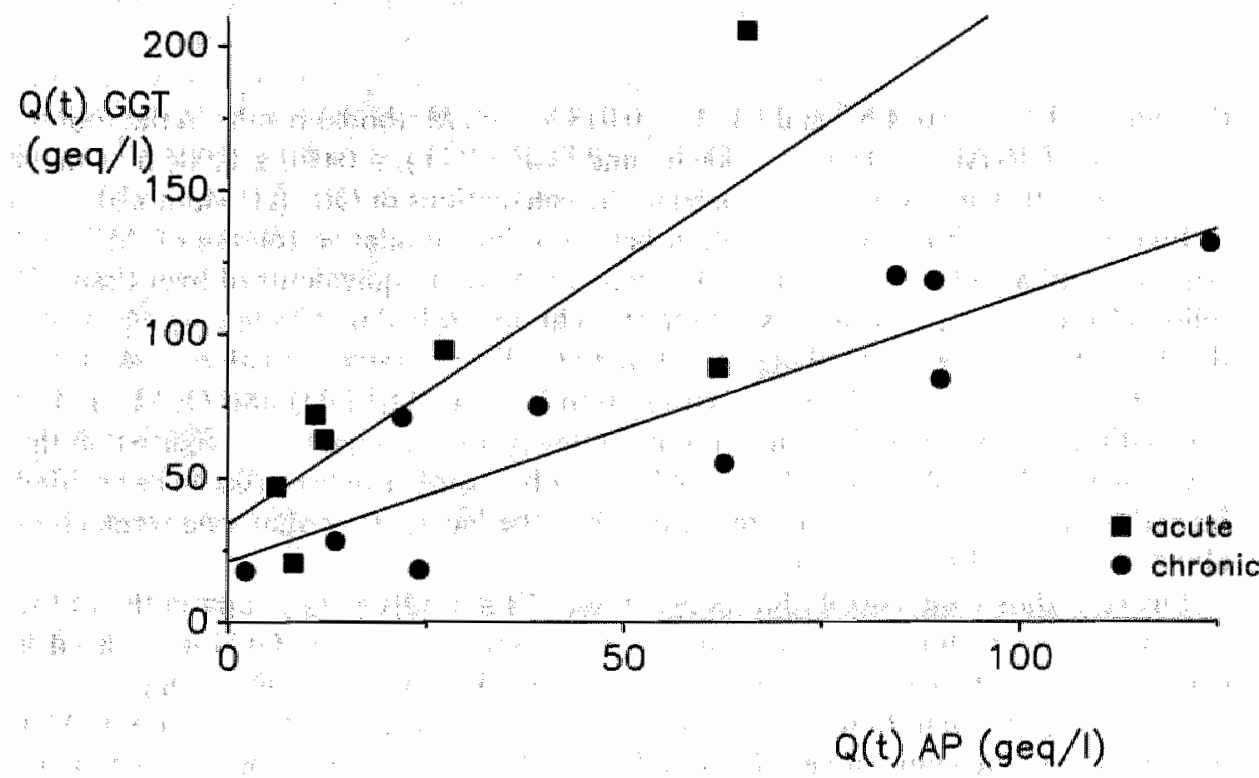

Figure 3. Cumulative release of enzyme activity of AP and GGT expressed as gram-equivalent of tissue per liter plasma (geq/) in acute and chronic biliary obstruction. The best fitting straight lines are $y=1.83 \mathrm{x}$ $+34(r=0.80)$ for the acute group and $y=0.92 x+21(r=0.88)$ for the chronic group. 


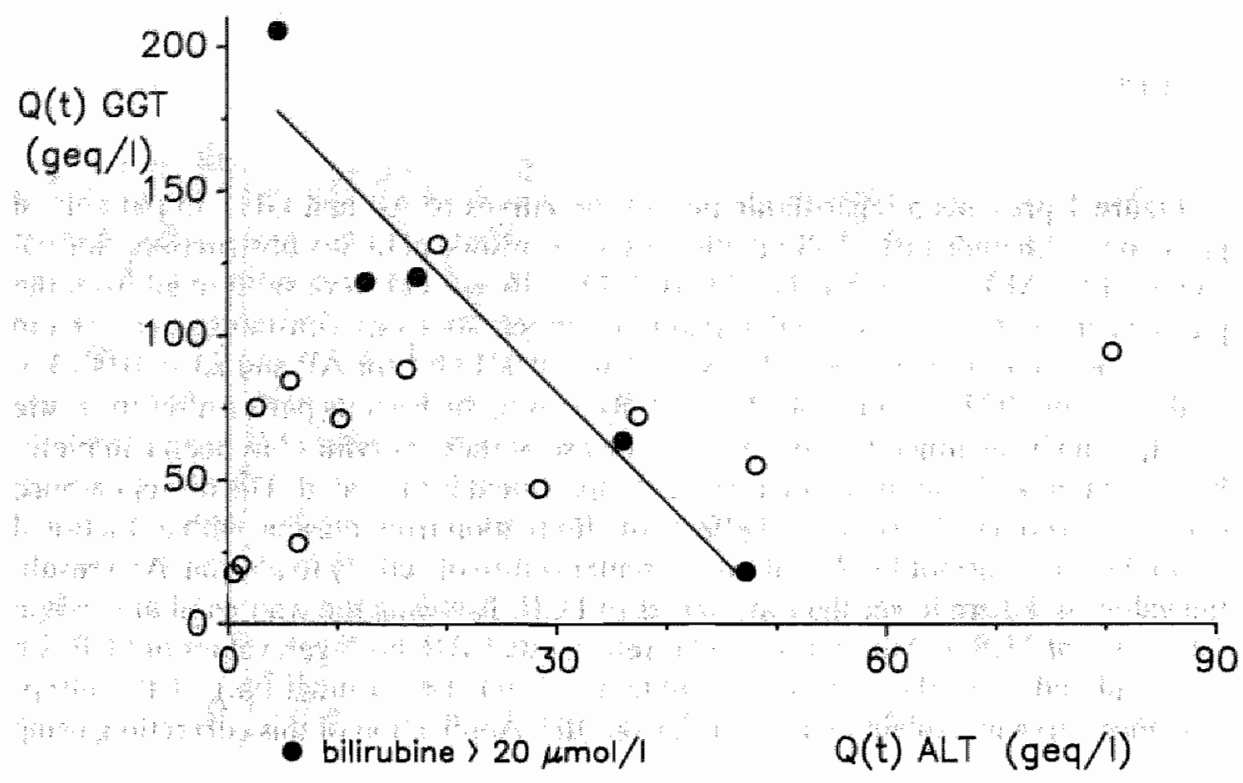

Figure 4. Cumulative release of ALT and GGT. For the patients with plasma bilirubine levels exceeding $20 \mu \mathrm{mol} / \mathrm{l}$ (mean $94 \mu \mathrm{mol} / \mathrm{l})$ an inverse relationship $\mathrm{y}=-3.8 \mathrm{x}+195(\mathrm{r}=0.96)$ is observed.

the values TER $=0.014 \mathrm{~h}^{-1}$ and ERR $=0.018 \mathrm{~h}^{-1}$ (cf. Methods) results in the following values: $F C R(A P)=0.025 \pm 0.006 \mathrm{~h}^{-1}$ and $\mathrm{FCR}(\mathrm{GGT})=0.020 \pm 0.004 \mathrm{~h}^{-1}$ (mean $\pm S E M, n=9$ ). These values were used in the calculations of $Q(t)$ (cf. Methods).

Figure 2 - top shows the correlation between the cumulative release of AST and ALT after biliary obstruction $(n=17)$ expressed in gram-equivalents of liver tissue. It follows from the slope of the best fitting straight line, calculated by linear regression, that the activities are released in proportion to the liver enzyme activities of cAST and ALT. Figure 2 - bottom shows the correlation between $Q(L D H)$ and $Q(A L T)$. The correlations observed are identical, but it follows from the slope of this figure that the liver releases threefold less LDH than ALT after biliary obstruction. As can be verified from this figure, there is no difference between the 'acute" (less than one week complaints) and the 'chronic' groups.

Figure 3 shows the correlation between $Q(A P)$ and $Q(G G T)$. Apparently, in the patients with a shorter history of biliary obstruction relatively more GGT is released as compared with AP, whereas this difference is leveled off in the chronic group.

Figure 4 shows that there is no correlation between the cumulative release of ALT (Q(ALT)) and the cumulative release of GGT (Q(GGT)). In patients with high plasma bilirubine levels there was a tendency to an inverse relationship.

The left side of Figure 5 - top shows that the pattern of AST and ALT release observed in patients with biliary obstruction due to malignancies is almost identical to the 
pattern observed in the other patients (cf. Figure 2). It seems that the release of LDH and ALT in these patients are not correlated (Figure 5 - bottom). However, the Figure 2 - bottom shows an identical behavior for patients with a total release of less than 30 geq/l. It seems as if the reduction in LDH release, compared to the release of ALT, is somewhat less in obstruction caused by malignant processes. For this observation release of LDH out of tumors could be responsible [14].

\section{DISCUSSION}

The method used in the present study for the estimation of FCR(AP) and FCR(GGT) can only be applied to slowly eliminated enzymes. The safety margin of four days, introduced to exclude a potential effect of tailing hepatic release, cannot be used for rapidly eliminated enzymes like $\mathrm{LDH}$ and AST because the plasma activities of these enzymes have returned to normal in such a period of time [11]. Values of $k_{d}$ as found in the present study approximates the value of $0.007 \mathrm{~h}^{-1}$ reported in $[15,16]$. The value of FCR(AP) $=0.025 \mathrm{~h}^{-1}$ is higher than the value of FCR(AP) $=0.008 \mathrm{~h}^{-1}$ reported in a study of infused placental AP infused in human subjects [17]. This discrepancy is probably explained by differences in the elimination rates of the isoenzymes of alkaline phosphatase [18].

The cumulative release of AST and ALT after biliary obstruction is completely in accordance with the proportion of these activities in liver tissue (Figure 2-top). A threefold decrease in hepatic LDH activity after biliary obstruction is confirmed in liver biopsies [8,9]. This decrease in LDH activity is not different in the acute group compared with the patients with more long-standing biliary obstruction (cf. Figure 2bottom): In view of the slow intracellular turnover of this enzyme (16 days in the rat [19] and probably longer in man), it may be that cholestatic injury has a considerable prodromal phase, of at least several weeks.

Increase in liver AST activity has been described, along with a decrease in liver ALT activity [20], but this study concerned patients with intrahepatic cholestasis. Other authors report an increase of both transaminases of about $10 \%$ in rat liver after bile duct ligation [21]. In Figure 3 cumulative release of GGT in the acute group seems higher than the cumulative release of AP activity. This may be the result of a higher initial rate of GGT induction. However, this is not confirmed by studies on membranebound enzyme activities in liver after experimental biliary obstruction in the rat. In these studies, the increase in AP activity in liver is about sevenfold, while the increase in GGT activity in liver is about threefold $[6,7,21,22]$. Another explanation of this discrepancy is offered by a difference in the solubilization of AP and GGT by accumulated bile salts. GGT could be more vulnerable to the detergent action of bile acids and would therefore more readily be released in the circulation after the onset of biliary obstruction. This hypothesis is supported by the observation that vesiculisation of GGT appears to occur more easily than AP as witnessed by the higher vesicle/plasma ratio of GGT activity as compared with the same ratio of AP activity [23]. 

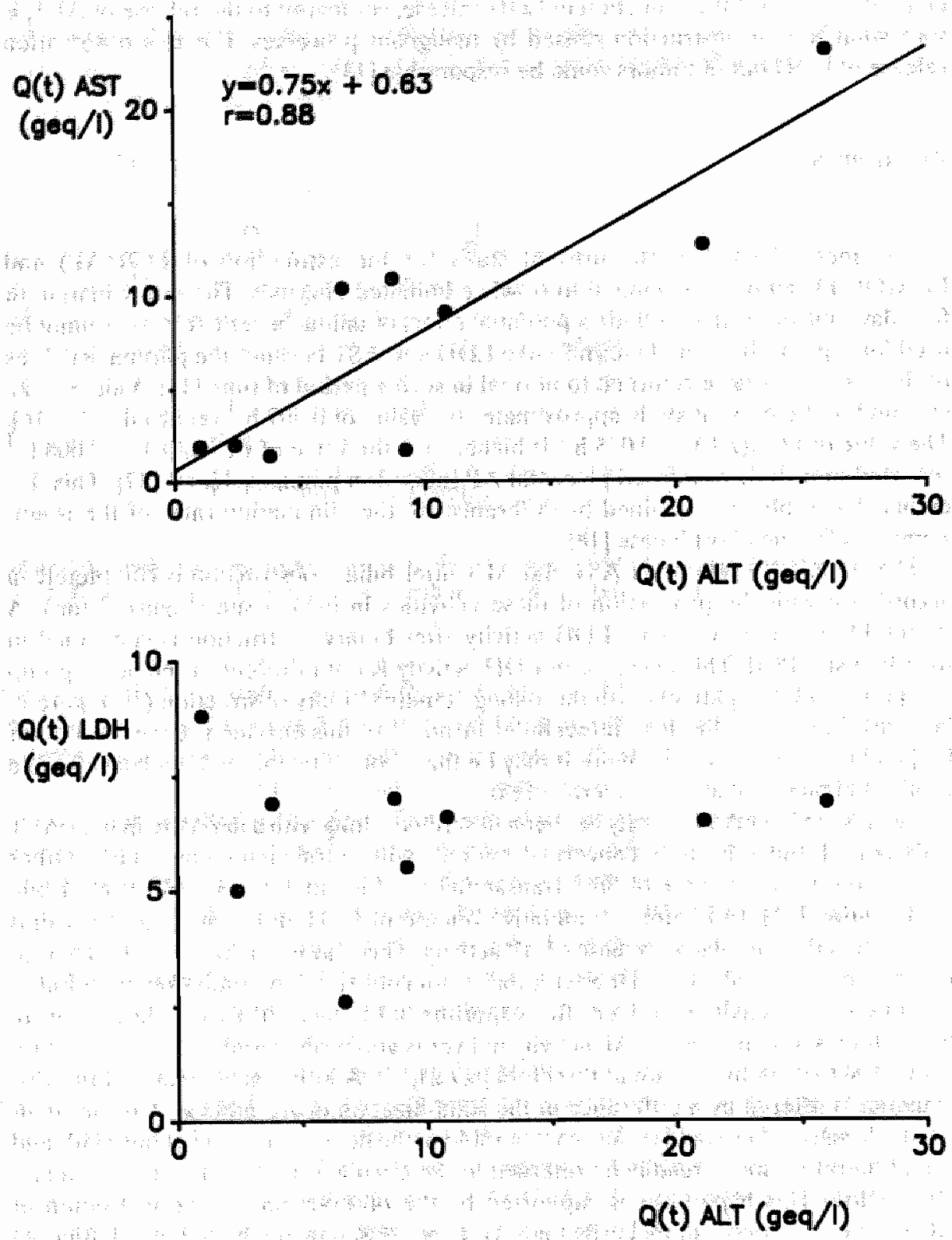

Figure 5. Cumulative release after biliary obstruction due to a malignant cause (cf. legend Figure 2). 
From Figure 4 it is apparent that there is no correlation between the cumulative release of ALT, that may be used as a marker of liver cell disruption, and the cumulative release of GGT, a membrane-bound enzyme. Rather, there appears to be an inverse relation, especially in patients with greater exposure to bile acids as evidenced by hyperbilirubinemia. Points in the left upper part of Figure 4 represent tissue with very few injured cells and an apparent high capacity for induction of GGT, points in the right lower part of the figure indicate liver tissue with extensive cell disruption, equivalent to 30 grams of liver tissue per liter of plasma, but low GGT activity. Apparently, induction of enzyme activity is a sign of adequate cell function and not indicating impending cell death.

Figure 5 shows the plots of cumulative release of AST, ALT and LDH in the patient group with cholestasis secondary to a malignancy obstructing the common bile duct. By comparison with the corresponding plots of the patient group with benign biliary obstruction (Figure 2), it is apparent that the mean cumulative release is smaller. Probably, this discrepancy is explained by the fact that, due to necrosis and edema, obstruction of bile ducts produced by tumors are seldom complete, and leading to a form of intermittent biliary obstruction.

If hyperbilirubinemia (cf. Figure 3) may be interpreted as a state concomitant with a high intrahepatic concentration of bile acids, a picture emerges in which cholestasis first induces de novo production of membrane-bound enzymes, followed by the shedding of membrane-bound enzymes through the detergent action of bile acids with possible disparate action on different enzymes. This state may proceed to prolonged detergent injury, with reduced induction of membrane enzymes, deteriorating in liver cell necrosis.

\section{REFERENCES}

1. Seetharam S, Sussman NL, Komoda T, Alpers DH. The mechanism of elevated alkaline phosphatase activity after bile duct ligation in the rat. Hepatology 1986;6:3374-380.

2. Schlaeger R, Haux P, Kattermann R. Studlies on the mechanisms of the increase in serum alkaline phosphatase in cholestasis: significance of the hepatic bile acid concentration for the leakage of alkaline phosphatase from rat liver. Enzyme 1982;28: 3-13.

3. Hatoff $\mathrm{DE}$, Hardison WG. Bile acids modify alkaline phosphatase induction and bile acid secretion pressure after bile duct ligation in the rat. Gastroenterology 1981;80:666-672.

4. Schmidt E, Schmidt FW. Fundamentals and evaluation of enzyme patterns in serum. In: Popper H, Schaffner F, eds. Progress in liver disease, vol.VII. New York; Grune \& Stratton 1982:411-428.

5. Bianchi-Bosisio Righetti A, Kaplan MM. Disparate responses of serum and hepatic alkaline phosphatase and 5'nucleotidase to bile duct obstruction in the rat. Gastroenterology 1972;62:1034-1039. 
6. Ideo G, Morganti A, Dioguardi N. Gamma-glutamyl transpeptidase: a clinical and experimental study. Digestion 1972;5326-336.

7. Schmidt FW. Enzymes in cholestasis. In. Bianchi L, ed. Liver and bile. Lancaster; MTP press 1977:203-214.

8. Schwarzmann $\mathrm{V}$, Couinaud C, Berthaux N Liver enzymes in biliary retention. Nature 1962,195:706707.

9. Schmidt E, Schmidt FW, Herfarth C, Opitz K, Vogell W. Studien zum Austritt von Zell-enzymen am Modell der isolierten, perfundierten Ratten-Leber. III. Mittellung , Analyse des bel Perfusion unter Hypoxie entstehenden extra cellulären Enzym-Musters. Enzym biol clin 1966;7:185-202.

10. Sehmidt E, Schmidt FW. Enzyme activities in human liver. Enzym biol clin $1970,11.67-129$.

11. Peltenburg HG, Hermens WTh, Willems GM, Flendrig JA, Schmidt E. Estimation of the Fractional Catabolic Rate constants (FCRs) for the elimination of cytosolic liver enzymes from plasma. Hepatology (submitted).

12. Sakakibara S, Shiomi K, Kobayashi S, Ikeda T, Irrai S, Kagamiyama H. A convenilent and sensitive method for the determination of serum aspartate aminotransferase isozymes after electropheresis. Clin Chim Acta 1983;133:119. 123.

13. Hermens WTh, Willems GM, Visser MP. Quantification of circulating proteins. The Hague: Martinus Nijhoff Publ, 1982.

14. Schmidt E, Schmidt FW. Die Bedeutung der enzymatischen Analyse in der Medizin. In, Bergmeyer HU, ed. Methoden der enzymatischen Analyse. Weinheim/Bergstr. Verlag Chemie, 1974: 6-30.

15. Klein UE, Schneider F, Sattler R. Über Eliminationshalbwertzeiten Cholestaseanzeigender Serumenzyme. Verh dtsch Ges inn Med 1975;81:1327-1329.

16. Schmidt E, Schmidt FW. Enzymologie. In: Siegenthaler W, ed. Klinische Pathophysiologie. Stuttgart, G. Thieme Verlag, 1982:177-195.

17. Clubb JS, Neale FC, Posen S. The behavior of infused placental alkaline phosphatase in human subjects. J Lab Clin Med 1965;66:493-507.

18. Goldstein DJ, Rogers CE, Harris H. Expression of alkaline phosphatase loci in mammalian tissues. Proc Natl Acad Sci USA 1980;77:2857-2860.

19. Schimke RT. Protein degradation in vivo and its regulation. Circ Res Supp 1 $1976,38: 1131-1137$.

20. Schmidt E, Schmidt FW. Aminotransferases in human pathology and clinical chemistry. In: Christen P, Metzler DE, eds. Transaminases. New York: John Wiley\&S, $1985: 587-624$.

21. Dioguardi N, Ideo G, Chiesara E. Cholestasis and enzymes. In: Gentilini P, Teodori U, Gorirni S, Popper $\mathrm{H}_{\text {, }}$ eds. Intrahepatic cholestasis. New York: Raven Press, 1975:141-151.

22. Dragosics B, Ferenci P, Pesendorfer F, Wewalka FG. Gamma-glutamyltranspeptidase (GGTP): Its relationship to other enzymes for diagnosis of liver disease. In: Popper H, Schaffner F, eds. Progress in liver disease. Vol. V. New York: Grune \& Stratton, 1976:436-449. 
23. De Broe ME, Borgers M, Wieme RJ. The separation and characterization of liver plasma membrane fragments circulating in the blood of patients with cholestasis. Clin Chim Acta 1975;59:369-372. 
Hसम क्ष

mos 


\section{CUMULATIVE RELEASE OF LIVER ENZYMES IN ALCOHOLIC}

\section{LIVER DISEASE}

\section{INTRODUCTION}

Enzymes play an important role in the diagnosis of alcoholic liver disease. Elevated plasma gamma-glutamyl transferase (GGT) activity, without or with less pronounced increase in alkaline phosphatase (AP) activity, and elevated plasma activities of aspar tate aminotransferase (AST) and alanine aminotransferase with a ratio increased above unity, are the most characteristic features of the enzyme pattern in the spectrum of alcoholic liver disease [1-4]. The elevated AST/ALT ratio could be caused by increased liver AST activity, as has been demonstrated for the mitochondrial subfraction of this enzyme [5], or by decreased ALT activity in liver. In plasma, mitochondrial AST (mAST) has seldom been found to be increased above $15 \%$ of total AST activity [8], adding to the general impression that mAST is not liberated easily in plasma. A decreased hepatic ALT content has been reported in several studies $[6,7]$ and therefore seems a more probable explanation for the high AST/ALT ratio.

The rise of GGT activity in plasma in chronic excessive alcohol intake is thought to be the result of induction of microsomal enzymes. In the liver the enzyme has been demonstrated histochemically and biochemically in the canaliculi of the parenchyma, and to a lesser extent also within the periportal bepatic cells $[9,10]$. As liver damage may frequently be accompanied by some degree of intrahepatic cholestasis [11], the plasma GGT activity increase is either the result of solubilization of enzyme from the plasma membrane or the release of enzyme after liver cell necrosis [12].

In order to study the quantitative aspects of these mechanisms one has to estimate the total activities of various enzymes released into plasma. Recently, the fractional catabolic rate constants (FCR) of cytosolic liver enzymes and GGT have been estimated $[13,14]$. By means of these values it became possible to calculate cumulative release after liver injury. It was shown that the release of cAST, LDH and ALT in a group of patients with acute liver injury, but without pre-existing hepatic disease, occurred in proportion to the activity of these enzymes in healthy control livers. Moreover, the large mean enzyme release, observed in these patients, equivalent to more than $400 \mathrm{gram}$ of liver tissue, indicated quantitative recovery of liver enzymes in plasma without significant loss of activity during transport of enzymes from damaged 
liver cells into the circulation. This suggests that calculation of cumulative release of liver enzymes in plasma may give useful information about changes in liver enzyme content. In this way by comparison of the cumulative release of various enzymes originating from the same cell compartment, one may also be able to discriminate between enzyme release due to cell necrosis, enzyme release due to 'blebbing', or phenomena such as local inactivation or denaturation ('Soforteffekt').

\section{PATIENTS AND METHODS}

Seven patients admitted to the University Hospital of Maastricht with a continuing alcohol problem, as demonstrated by a history of alcoholic liver disease and in 3 cases proven by biopsy, and with a plasma ALT increase above $50 \mathrm{U} / \mathrm{l}$ without increased plasma creatine kinase entered the study. Patients with a mAST fraction exceeding $15 \%$ were excluded. Samples were taken at approximately 12-24 hour intervals. Three patients from the outpatient clinic of the Maasland Hospital, all with histologically proven alcoholic liver disease, were asked for daily plasma samples on 4 consecutive days, the first of which was within 2 days after their consent.

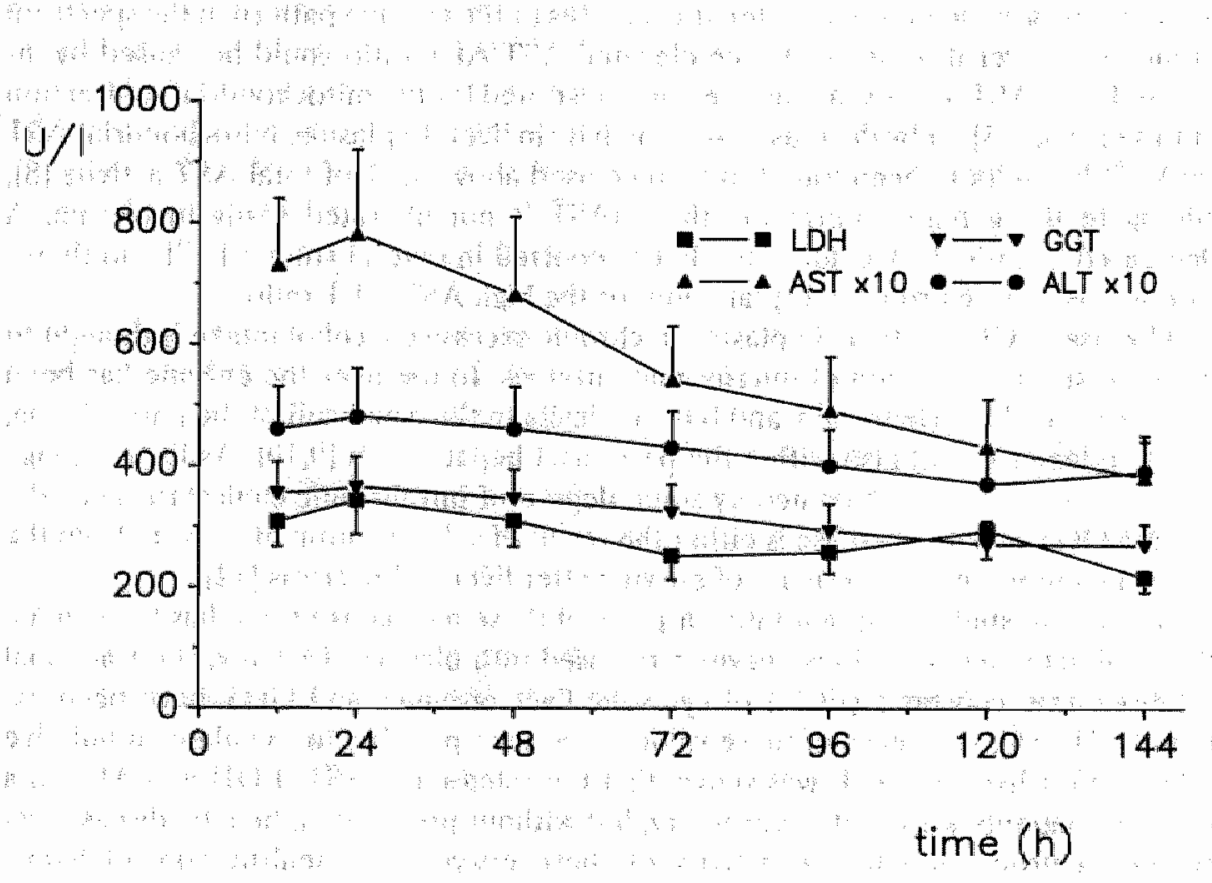

Figure 1. Mean plasma time-activity curves of lactate dehydrogenase (LDH), aspartate aminotransferase (AST), alanine aminotransferase (ALT), and gamma-glutamyl transferase (GGT), ( $n=7$, SEM is indicated). In-hospital follow-up. 


\section{METHODS}

\section{Enzyme determinations}

Venous blood samples were centrifuged and the plasma was stored at $-20^{\circ} \mathrm{C}$. Enzyme activities of aspartate aminotransferase (AST; EC 2.6.1.1), alanine aminotransferase (ALT; EC 2.6.1.2), lactate dehydrogenase (LDH; EC 1.1.1.27) and gamma-glutamyl transferase (GGT; EC 2.3.2.2) were determined using a centrifugal analyzer (Cobas Bio - Hoffmann La Roche). All results are expressed as micromoles of substrate converted per minute (U/1). Enzyme activities were measured at $25^{\circ} \mathrm{C}$. Commercially available test kits (Boehringer Mannheim) were used. Cytosolic and mitochondrial AST were separated on LD gels (Paragon, Beckman) with the method described by Sakakibara [15]. The procedure was carried out on a Beckman type P/N 65580 electrophoresis apparatus.

\section{Assessment of cumulative enzyme release}

The method describing assessment of cumulative enzyme release is described in [16].

Cumulative release of enzyme activity per liter of plasma from zero time up to time $t$ was calculated from:

$$
\mathrm{Q}(\mathrm{t})=\mathrm{C}(\mathrm{t})+\mathrm{TER} \cdot \exp (-\mathrm{TER} \cdot \mathrm{t}) \cdot \int_{0}^{t} \exp (\mathrm{ERR} \cdot \mathrm{t}) \mathrm{C}(\mathrm{t}) \mathrm{dt}+\mathrm{FCR} \cdot \int_{0}^{t} \mathrm{C}(\mathrm{t}) \mathrm{dt}
$$

where $C(t)$ is the plasma enzyme activity $(\mathrm{U} / \mathrm{l})$ measured at time $t$. The second term represents the enzyme activity in the extravascular pool. The last term represents the catabolized fraction of enzyme activity up to time t. Values for $C(t)$ are obtained by subtracting the normal steady-state plasma enzyme activity from the plasma activity actually measured. Values for the fractional catabolic rate constants (FCR), the transcapillary escape rate (TER) and the extravascular return rate (ERR) used in the calculations were: $\mathrm{FCR}(\mathrm{LDH})=0.13 \mathrm{~h}^{-1}, \mathrm{FCR}(\mathrm{AST})=0.088 \mathrm{~h}^{-1}, \mathrm{FCR}($ ALT $)=0.034$ $\mathrm{h}^{-1}$, FCR(GGT) $=0.02 \mathrm{~h}^{-1}$, TER $=0.014 \mathrm{~h}^{-1}$, and ERR $=0.018 \mathrm{~h}^{-1}[13,14]$.

Cumulative release of enzyme was expressed in gram-equivalents of healthy liver per liter of plasma. To this end cumulative release was then divided by the mean activities in control livers expressed per gram of wet weight, i.e. $16 \mathrm{U} / \mathrm{g}$ for CAST, $17 \mathrm{U} / \mathrm{g}$ for $A L T, 117 \mathrm{U} / \mathrm{g}$ for $\mathrm{LDH}$ and $5.8 \mathrm{U} / \mathrm{g}$ for GGT $[13,14]$.

Significance of differences in mean values were calculated with the student's t-test.

\section{RESULTS}

Figure 1 shows the mean plasma time activity curves $( \pm S E M, n=7)$ for the patients in this study. After hospitalization GGT activity in plasma gradually declines. Plasma 

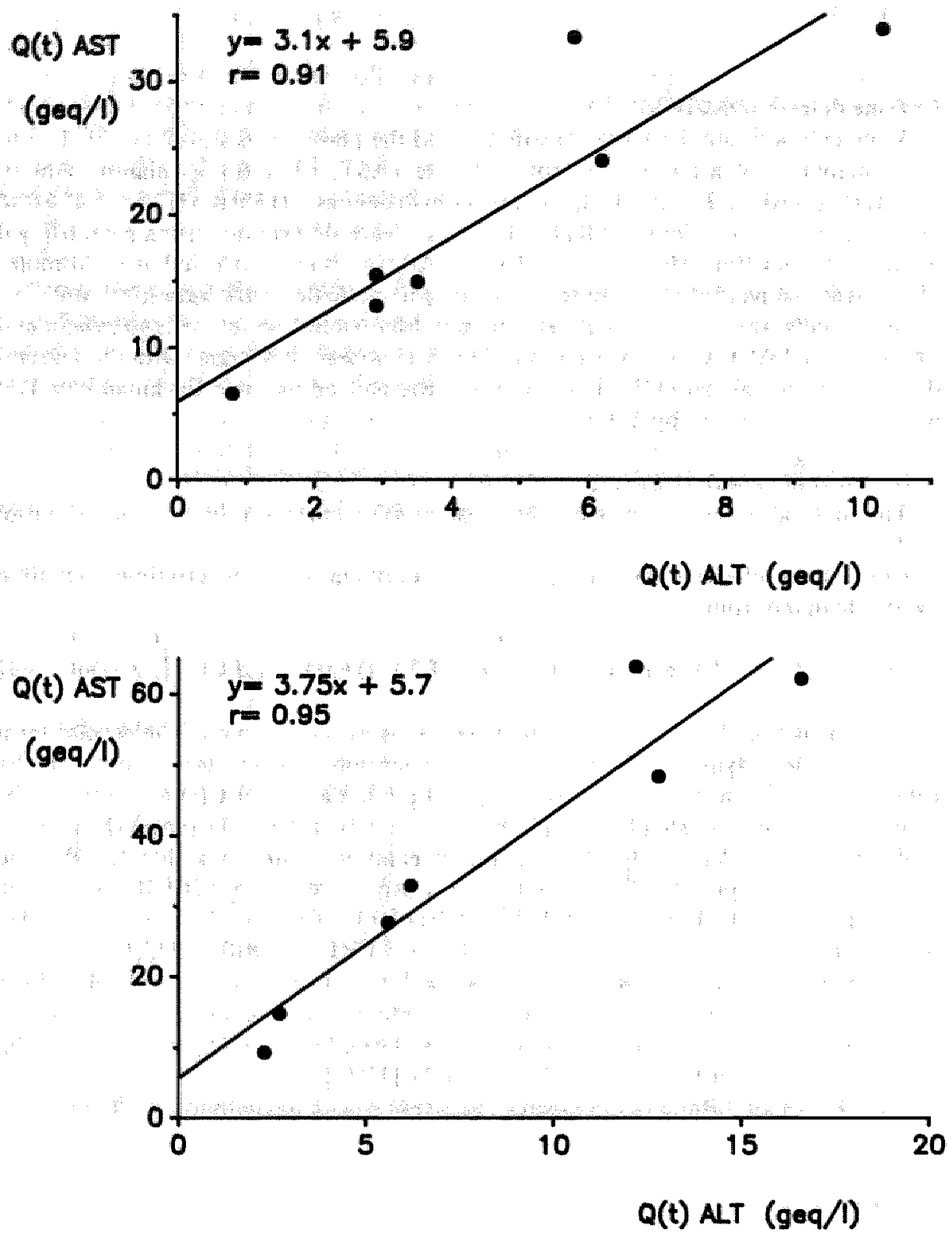

Figure 2. Scatter plot of cumullative enzyme release of ALT and AST up to $48 \mathrm{~h}$ (top figure) and up to 144 h (bottom figure): Cumulative enzyme activity per liter of plasma is divided by the activity per gram wet weight of liver (geq/)). The best fitting straight line is calculated by linear regression. 
LDH activity is only slightly elevated and remains more or less constant during 6 days. AST and ALT remain both elevated and the ratio AST/ALT is above unity during the whole period Individual data on cumulative enzyme are presented in Table 1.

Figure 2 - top shows the correlation $(r=0.94)$ between the cumulative release of ALT and AST up to 48 h. Comparison with Figure 2-bottom, which presents cumulative release of ALT and AST up to $144 \mathrm{~h}$, enzyme release is ongoing and apparently occurs in the same ratio of activities over the entire time period.

Figure 3 - top shows the correlation $(r=0.91)$ between the cumulative release of AST and LDH up to $48 \mathrm{~h}$, and again up to $144 \mathrm{~h}$ (Figure 3 - bottom). The same conclusion may be drawn here: release is ongoing and occurs in a constant proportion during the six days of observation.

Figure 4 shows the relation between total release of AST, chosen as the marker of liver necrosis, and total release of GGT over $144 \mathrm{~h}$. A mean cumulative release rate of AST of about 6 geq///day correlates only globally with a mean release rate of 42 geq//day for GGT $(r=0.73)$. Apparently, there is an induction of GGT in liver tissue, resulting in an approximately sevenfold increase in activity.

Table 2 shows the plasma enzyme ratios after 48 hours and 144 hours. Peak values of plasma enzyme activity in the first $48 \mathrm{~h}$ and between 96 and $144 \mathrm{~h}$ are shown. The decrease of peak ratio AST/ALT in the first $48 \mathrm{~h}$ as compared with the same peak ratio in the last two days of observation is statistically significant $(\mathrm{p}<0.001)$. In contrast to this decrease in the AST/ALT ratio of plasma activities, the proportion of cumulative released activities remains constant over the entire observation period (cf. Figure 2).

Figure 5 presents plasma time activity curves of four enzymes in three patients during four days follow-up of ambulatory patients. The plasma enzyme activities in this Figure indicate that these patients were in a stationary phase. In this situation, the extravascular volume is saturated with enzymes and cumulative release in one day may be approximated then by the equation:

$$
Q(t)=C(t) \times 24 \times \text { FCR } \times P V
$$

in which $P V$ is the plasma volume estimated at three liters, the other terms are explained in the preceding equation. This daily release is divided by the gram-equivalent value of enzyme in liver, as has already been explained in the Methods section.

Calculated for AST the release amounts to $(40-20) \times 24 \times 0.088 \times 3 / 16=$ about $8 \mathrm{~g}$ of liver tissue per day.

\section{Discussion}

The fractional catabolic rate constants of cytosolic liver enzymes and the ratios of released enzyme activities into plasma were recently estimated [13]. The patients in that study had a normal liver status before occurrence of the acute event and the estimated ratios corresponded to the tissue enzyme ratios in healthy liver. Recent experimental studies have demonstrated complete recovery in plasma of enzymes lost 
from the heart [17], and from kidney [18]. In the liver with its intimate contact between liver cell, space of Disse and plasma, and its rapid lymphatic transport through the thoracic duct, the conditions for a quantitative recovery of enzymes in plasma are even more favorable than in the heart or the kidney. Accordingly, liver enzymes are probably released completely and enter the plasma quickly after liver cell injury, offering the opportunity for a quantitative approach toward liver enzyme release.

Figure 2 suggests that in alcoholism the liver contains three times more AST, or three times less ALT, than the normal liver. Although increased hepatic AST activity has never been reported, induction of the mitochondrial subfraction has been demonstrated in alcoholic liver disease [5]. Samples were checked for the mitochondrial isoenzyme of AST, but mAST was generally onlly a small percentage of total AST activities. This is in agreement with other estimates of mAST in alcoholic liver disease [8], and plasma mAST activity can therefore not explain this altered ratio. A decreased content of ALT, however, has been demonstrated earlier in alcobolic liver injury $[6,7]$.

Figure 3 also suggests a decrease of liver LDH content by about $40 \%$, but a decrease of this magnitude is not confirmed in studies on liver enzyme content. Taken together, these data indicate that chronic alcoholism results in a marked lowering of hepatic ALT by a factor of about three, unchanged or slightly elevated AST activity and approximately unaltered or slightly decreased LDH activity.

In a previous study on cholestatic liver injury no correlation could be demonstrated between cumulative enzyme release of membrane-bound enzymes and cytosolic liver enzymes [14]. Figure 4, however, shows a correlation between AST and GGT, be it weak. As defects in membrane assembly have been demonstrated in alcoholic liver disease (cf. [19] for a review), one explanation may be that accumulation of untransported gamma-glutamyl transferase in the cytosol causes a behavior similar to other cytosolic enzymes.

Comparison of plasma ratios in Table 2 with the correlations of the cumulative release of ALT, AST and LDH (cf. Figures 2 and 3), invites to certain conclusions

Table 1. Cumulative release of enzyme up to $144 \mathrm{~h}$ (geq/)

\begin{tabular}{lcrccc}
\hline Patient & LDH & AST & ALT & GGT \\
\hline 1 & 32.5 & 62.1 & 16.6 & 217 \\
2 & 12.5 & 9.3 & 2.3 & 163 \\
3 & 43.1 & 63.8 & 12.2 & 394 \\
4 & 33.1 & 48.3 & 12.8 & 225 \\
5 & 10.4 & 27.6 & 5.6 & 187 \\
6 & 4.2 & 14.8 & 2.7 & 119 \\
7 & 22.3 & 32.9 & 6.2 & 287 \\
mean & 22.6 & 37.0 & 8.3 & 227 \\
sem & 5.4 & 8.2 & 2.1 & 34 \\
\hline
\end{tabular}



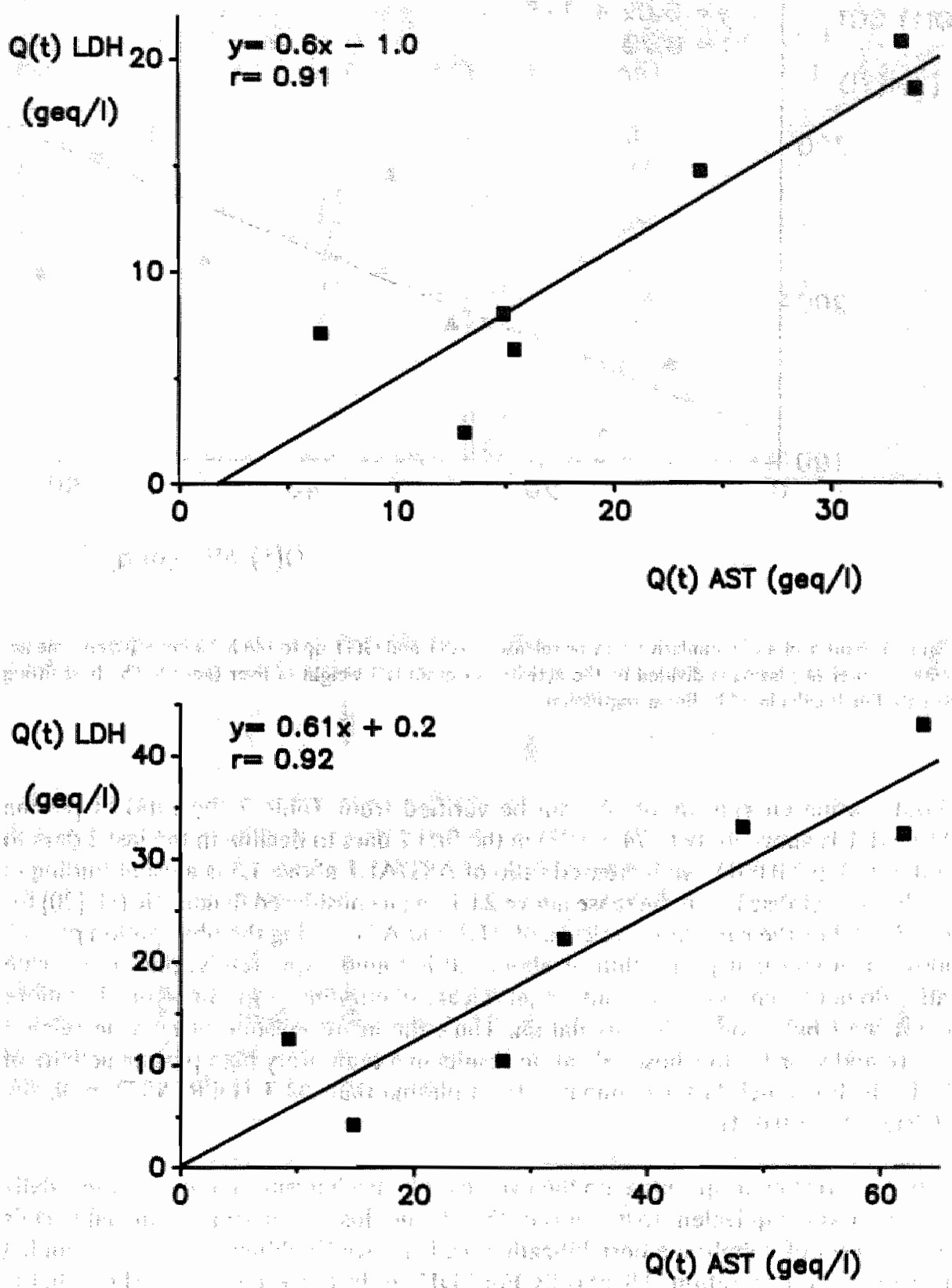

Figure 3. Scatter plot of cumulative enzyme release of AST and LDH up to $48 \mathrm{~h}$ (top figure) and up to 144 h (bottom figure). Camulative enzyme activity per liter of plasma is divided by the activity per gram wet weight of liver (geq/). The best fitting straight line is calculated by linear regression. 


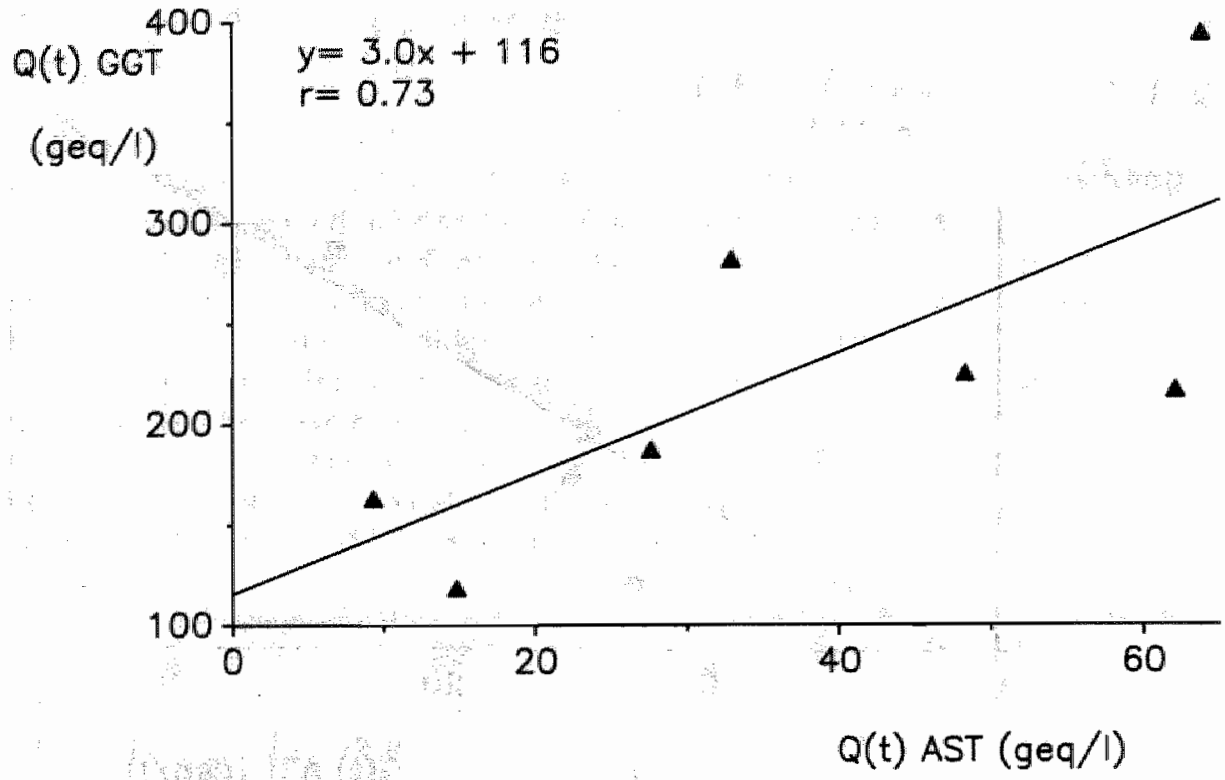

Figure 4. Scatter plot of cumulative enzyme release of AST and GGT up to $144 \mathrm{~h}$. Cumulative enzyme activity per liter of plasma is divided by the activity per gram wet weight of liver (geq/1). The best fitting straight line is calculated by linear regression.

about plasma enzyme ratios. As can be verified from Table 2 the ratio of plasma AST/ALT is above unity $(1.74 \pm 0.07)$ in the first 2 days to decline in the last 2 days to $(1.0 \pm 0.13, \mathrm{p}<0.001)$. An increased ratio of AST/ALT above 1.5 is a usual finding in alcoholic liver disease, an increase above 2.0 is even considered diagnostic (cf. [20] for a review). For the cumulative release of ALT and AST during the observation period, however, a constant proportion of about 3.0 is found. Apparently, plasma enzyme ratios do not teach us much about actual release of enzymes from the tissue, but more about their behavior in the circulation. Thus, the acute episode of enzyme release before and shortly after hospitalization results in a temporary high plasma activity of AST which is much faster eliminated from plasma than ALT (FCR(AST) $=0.088$, $\mathrm{FCR}(\mathrm{ALT})=0.034)$.

It is interesting to speculate on the two possible mechanisms that may cause a daily loss of enzyme equivalent to 8 grams of liver tissue: loss of enzymes from viable cells by a process of membrane destabilization, cell surface "blebbing" [21] or continuing necrosis and regeneration of liver cells. For $\mathrm{LDH}$, for instance, it has been shown in the rat that intracellular turnover is about $5 \%$ per day [22] and even slower after intake of ethanol $[23,24]$ whereas the maximal capacity of regeneration is estimated at about $50 \%$ per day $[25,26]$ and this capacity is not impaired in a chronic alcoholic state 
Table 2. Peak plasma enzyme activities in the first $48 \mathrm{~h}$ and between 96 and $144 \mathrm{th}$ (U/1)

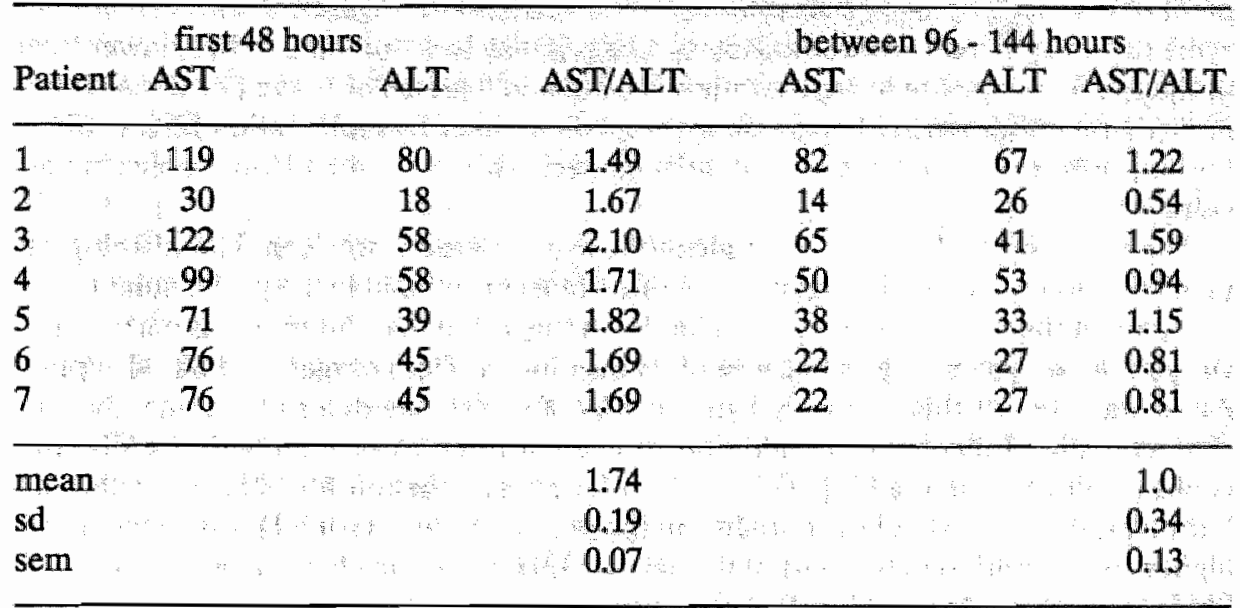

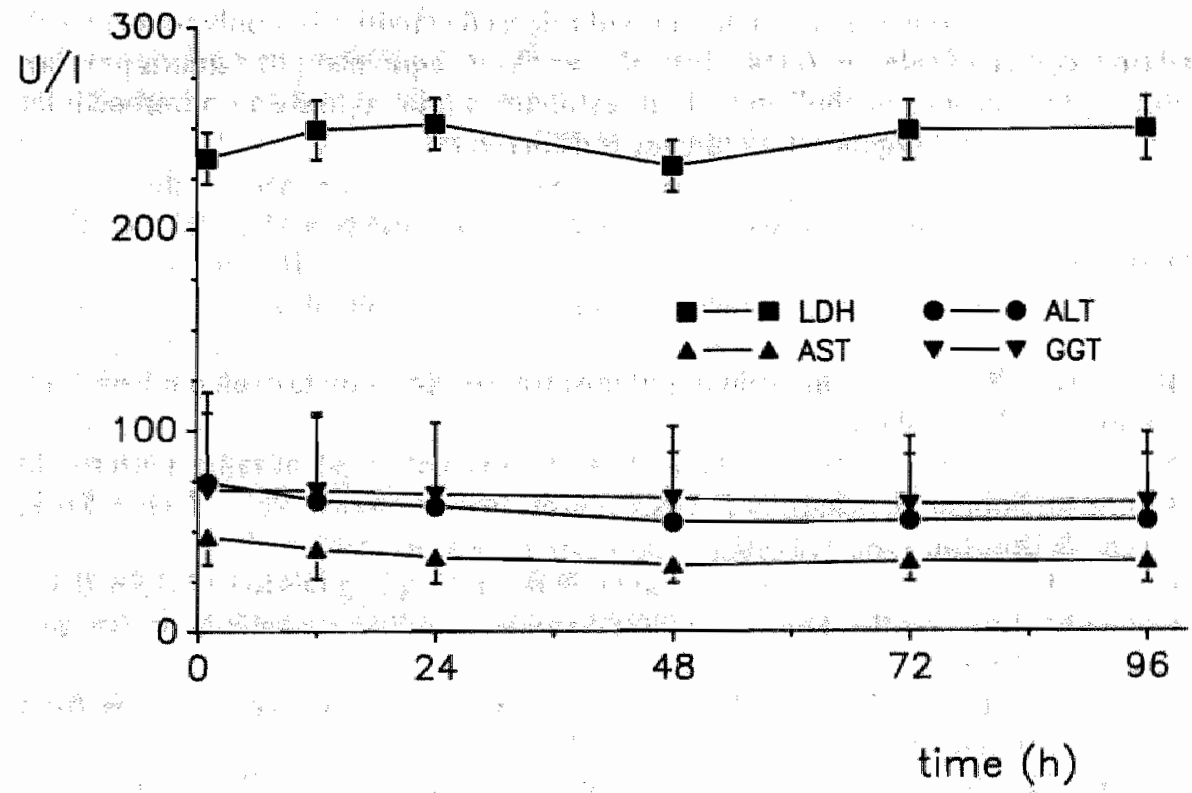

Figure 5. Mean plasma time- actiwity curves of lactate dehydrogenase (LDH), aspartate aminotransferase (AST), alanine aminotransferase (ALT), and gamma-glutamyl transferase (GGT), $(n=3$, SEM is indicated). Ambulatory follow-up. 
$[27,28]$. These figures indicate that regeneration has a higher capability for replenishment of liver LDH activity than synthesis in surviving cells. Figures on intracellular enzyme turnover in man are scarce, but, as a rulle, it may be assumed that it is slower than in the rat. The capacity of regeneration is large and 8 grams of tissue per day seems a realistic rate after partial hepatectomy or awxiliary liver transplantation [29]. Little is known, however, about the regenerative capacity of the human liver in chronic alcoholism.

The cause of ALT depletion in alcoholic liver disease is unclear. The histological manifestations of alcoholic hepatitis are often most prominent in the perivenular (zone 3) region of the hepatic acinus [30]. It has been suggested that this region is particularly vulnerable to hypoxic injury because of its location far from oxygenated blood supply. An aggravation of this relatively hypoxic state, for instance due to hypermetabolism characteristic of alcoholics in addition to anemia often associated with the disease, could result in ischemia [31]. This could offer an explanation for enzyme depletion. However, ALT is particularly enriched in the periportal zone (zone 1), with a factor 2.8 higher concentration in this part of the acinus [32] and this mechanism is therefore unlikely to cause a relative ALT depletion.

This study demonstrates that the changes in hepatic enzyme content observed in chronic alcoholism can also be estimated from cumulative enzyme release in plasma. From these data it may be concluded that ALT is depleted in liver tissue. It is also shown that the changes in the AST/ALT ratio in the acute versus the chronic phase do not correspond to a real change in the ratio of released activities but only reflect an altered time course of release. A daily loss of liver tissue, equivalent to 8 grams per day, is estimated in chronic alcoholism and this estimate is related to data on intracellular enzyme turnover and regeneration of liver cells in the rat.

\section{REFERENCES}

1. Rosalki SB, Rau D. Serum gamma-glutamyl transferase activity in alcoholism. Clin Chim Act 1972;39:41-47.

2. Schmidt E, Schmidt FW. Fundamentals and evaluation of enzyme patterns in serum, In: Popper H, Schaffner F, eds. Progress in liver disease, vol.VII. New York; Grune \& Stratton 1982:411-428.

3. Correia JP, Alves PS, Camilo EA. SGOT-SGPT ratios. Dig Dis Sci 1981;26:284.

4. Cohen JA, Kaplan MM. The SGOT/SGPT ratio - an indicator of alcoholic liver disease. Dig Dis Sci 1979;24:835-838.

5. Jenkins $W \mathrm{j}$, Peters $T J$. Mitochondrial enzyme activities in liver biopsies from patients with alcohollic liver disease. Gut 1978;19:341-344.

6. Schmidt E, Schmidt FW. Enzym muster der verfetteteten menschlichen Leber. XI. Mitteilung, Ferment-Aktivitäts-Bestimmung in der menschlichen Leber. Klin Wschr 1963;41:643-646.

7. Matloff DS, Selinger MJ, Kaplan MM. Hepatic transaminase activity in alcoholic liver disease. Gastroenterology 1980;78:1389-1392. 
8. Nalpas B, Vassault A, Charpin $S$, Lacour B, Berthelot $P$. Serum mitochondrial aspartate aminotransferase as a marker of chronic al coholisms diagnostic value and interpretation in a liver unit. Hepatology 1986;6:608-614.

9. Albert Z, Orlowska J, Orlowski M, Szewczuk A. Histochemical and biochemical investigations of gamma-glutamyl transpeptidase in the tissues of man and laboratory rodents. Act Histochem 1966;25:312-320.

10. Glenner GG, Folk JE, McMillan PJ Histochemical demonstration of a gammaglutamyl transpeptidase-like activity. I Histochem Cytochem 1962;10:481-489.

11. Glover SC, McPhie JL, Brunt PW. Cholestasis in acute liver disease. Lancet 1977;ii: $1305-1306$.

12. Wu A, Slavin G, Levi Aj. Elevated serum gamma-glutamyl transferase (Transpeptidase) and histological liver damage in alcoholism. Am J Gastroenterology 1976;65:318-323.

13. Peltenburg HG, Hermens WTh, Willems GM, Flendrig JA, Schmidt E. Estimation of the Fractional Catabolic Rate constants (FCRs) for the elimination of cytosolic liver enzymes from plasma. Hepatology (submitted).

14. Peltenburg HG, Kop- Klaassen B, Flendrig JA, Hermens WTh. Cumulative enzyme release in cholestasis. (et. chapter 5).

15. Sakakibara S, Shiomi K, Kobayashi S, Ikeda T, Irrai S, Kagamiyama H. A convenient and sensitive method for the determination of serum aspartate aminotransferase isozymes after electropheresis. Clin Chim Acta 1983;133:119123.

16. Hermens WTh, Willems GM, Visser MP. Quantification of circulating proteins. The Hague: Martinus Nijhoff Publ., 1982.

17. Hermens WTh, Van der Veen FH, Willems GM, Bouman ML, Schrijvers-Van Schendel A, Reneman RS. Complete recovery in plasma of cardiac enzymes lost from infarcted tissue after permanent coronary artery occlusion in the dog. Circulation (submitted).

18. Maessen JG Evaluation of ischemic injury in donor kidneys. An experimental study (thesis), Maastricht, 1988.

19. Tuma DJ, Sorrell MF. Effects of ethanol on protein trafficking in the liver. Sem Liv Dis 1988;8:69-80.

20. Salaspuro M. Use of enzymes for the diagnosis of alcohol-related organ damage. Enzyme 1987;37:87-107.

21. Trump BF, Pentilla A, Berezesky IK. Studies on cell surface conformation following injury. Virch Arch B Cell Path 1979;29:281-307.

22. Schimke RT. Protein degradation in vivo and its regulation. Circ Res Supp 1 1976;38:1131-1137.

23. Kirsh RE, Frith LOC, Stead RH et al. Effect of alcohol on albumin synthesis by the isolated perfused rat liver. Am J Clin Nutr 1973;26:1191-1194.

24. Morland J. Incorporation of labelled amino acids into liver protein after acute ethanol administration. Biochem Pharmacol 1975;24:439-442.

25. Karran SJ, Leach KG, Blumgart LH. Assessment of liver regeneration in the rat using the gamma camera. J Nucl Med 1974;15:10-16.

26. Harkness RD. Regeneration of the liver. Br Med Bull 1957;13:87-93. 
27. Orrego H, Crossley IR, Saldivia V, Medline A, Varghese G, Israel Y. Long-term ethanol administration and short-and long-term liver regeneration after partial hepatectomy. I Lab Clin Med 1981;57:221-230.

28. Frank WO, Rayyes AN, Washington A, Holt PR. Effect of ethanol administration upon hepatic regeneration. J Lab Clin Med 1979;93:402-413.

29. Terpstra OT, Schalm SW, Weimar W, willemse PA, Baumgartner D, Groenland THN, Ten Kate FWJ, et al. Auxiliary partial liver transplantation for end-stage chronic liver disease. New Eng J Med 1988;319:1507-1511

30. Horn T, Junge J, Christoffersen P. Early alcoholic liver injury: changes of the Disse space in acinar zone 3. Liver 1985;5:301-310.

31. Israel Y, Videla L, Bernstein J. Liver hypermetabolic state after chronic ethanol consumption: hormonal interrelations and pathogenic implications. Fed Proc 1975;34:2052-2059.

32. Welsh FA. Changes in the distribution of enzymes within the liver lobule during adaptive increases. J Histochem Cytochem 1972;20:107-111. 
CHAPTER 7

Greater than Expected Alanine Aminotransferase Activities in Plasma

and in Hearts of Patients with Acute Myocardial Infarction

Peter L.A. Giessen, Henny G. Peltenburg, Chris de Zwaan, Piet C.W. Janson, J. Guus Flendrig, and Wim Th. Hermens. Clinical Chemistry 1989:35;279-283.

\section{INTRODUCTION}

Enzymatic assessment of the extent of cardiac injury after acute myocardial infarction has recently been applied on a large scale in the evaluation of early thrombolytic treatment of $\mathrm{AMI}^{*}$ [1-3]. These studies show that cytosolic cardiac enzymes are released in plasma in proportion to their activities in myocardium and this allows the use of gram-equivalents of infarcted tissue as a measure for cardiac injury, that is independent of the specific marker enzyme $[2,4,5]$. This holds also true for alanine aminotransferase (ALT, EC 2.6.1.2). The normal ALT activity in the human heart is low but, in spite of modest increases in ALT in plasma after AMI, estimates of infarct size based on ALT release in plasma correlated well with the estimates based on alphahydroxybutyrate dehydrogenase (HBDH, EC 1.1.1.27) [6].

In large groups of patients with AMI, however, it was noted that the early increase in plasma ALT activity in plasma was so disproportionately great. The time course of ALT release in these patients was similar to the release pattern of myocardial marker enzymes such as creatine kinase (CK, EC 2.7.3.2) and $\mathrm{HBDH}$, suggesting that the extra ALT originated from the heart.

In the present study this phenomenon was investigated in a large group of patients with $\mathrm{AMI}$, admitted to a coronary-care unit. In addition, myocardial enzyme activities were determined in hearts obtained from patients who died after AMI and in control hearts.

- $\quad \mathrm{AMI}=$ Acute myocardial infarction 

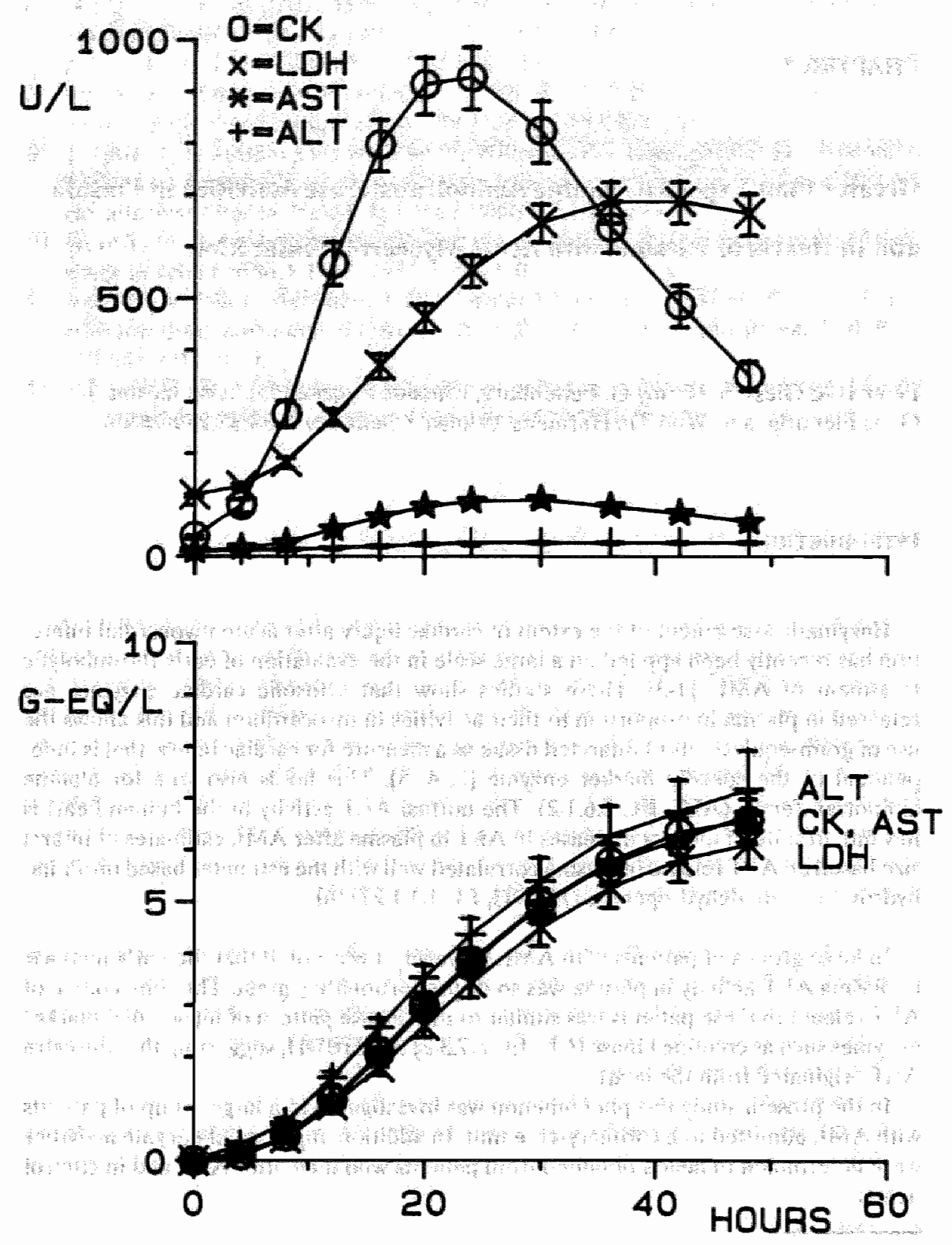

Figure 1. Plasma enzyme activities (upper figure) and cumulative release of enzymes, expressed in gramequivalents of heart tissue per liter of plasma (lower figure), in group 1. SEM is indicated. 


\section{PATIENTS AND METHODS}

Plasma enzyme activities were studied in three groups of patients. Group 1 represents the normal behavior after AMI. Group 2 consists of selected patients who had relatively high ALT activities in their plasma after AMI. Group 3 illustrates the effect of acute ischemic liver injury.

Group 1 consisted of 43 patients who formed the local control group in a recent multicenter trial on the effect of streptokinase after AMI [2]. These patients were admitted to the hospital within $4 \mathrm{~h}$ after onset of symptoms and they received standard conventional treatment. Enzyme activities were determined in plasma samples obtained immediately after admission to the coronary-care unit and $4,8,12,16,20,24,30$, 36,42 and 48 h thereafter.

A first selection for group 2 consisted of 29 patients with relatively high ALT activity in their plasma after AMI. These patients were selected from 750 patients discharged from the University Hospital Maastricht in 1986 and 1987, and showed maximal plasma ALT activities that exceeded 5\% of the maximal CK activities in the first $24 \mathrm{~h}$ after AMI. The following additional conditions were used in the selection for group 2: Plasma enzyme activities were determined at least every $8 \mathrm{~h}$ during the first $24 \mathrm{~h}$ and then every $12 \mathrm{~h}$ up to $48 \mathrm{~h}$.

The CK activity pattern in plasma was typical for recent AMI, the maximum level being reached between 15 and $30 \mathrm{~h}$ after admission. Patients subject to cardioversion were excluded ALT and aspartate aminotransferase (AST, EC 2.6.1.1) activities had to be $<80 \mathrm{U} / \mathrm{L}$ in the first plasma sample, to exclude pre-existing liver injury. Of these conditions, the first was not fulfilled in 5 , the second not in 1 , and the third not in 7 cases, resulting in a total of 16 patients for group 2 .

Group 3 consisted of 11 patients who suffered from various forms of shock $(n=5)$ or from right-side heart failure $(n=6)$. Acute ischemic liver injury was evidenced by a rapid rise in plasma ALT and AST activities. Plasma was sampled at least every $8 \mathrm{~h}$ during the first $48 \mathrm{~h}$.

\section{Determination of plasma enzyme activities}

The plasma activities of CK, lactate dehydrogenase (LDH, EC 1.1.1.27), AST and ALT were determined spectrophotometrically in a centrifugal analyzer (Cobas Bio system, Hoffnann- La Roche) with commercially available test kits (from Merck for $\mathrm{CK}$ and from Boehringer for the other enzymes). Samples from patients in groups 1 and 3 were determined at $25{ }^{\circ} \mathrm{C}$. Samples from group 2 were determined with identical equipment and test kits but at a temperature of $37{ }^{\circ} \mathrm{C}$; these activities were corrected to $25^{\circ} \mathrm{C}$ by multiplication by a temperature conversion factor according to user's instructions ( 0.43 for CK, 0.54 for LDH, 0.49 for AST and 0.53 for ALT). Enzyme activities are expressed in micromoles of substrate converted per minute (U), either per liter of plasma (U/L) or per gram wet weight (U/g). For each patient normal 

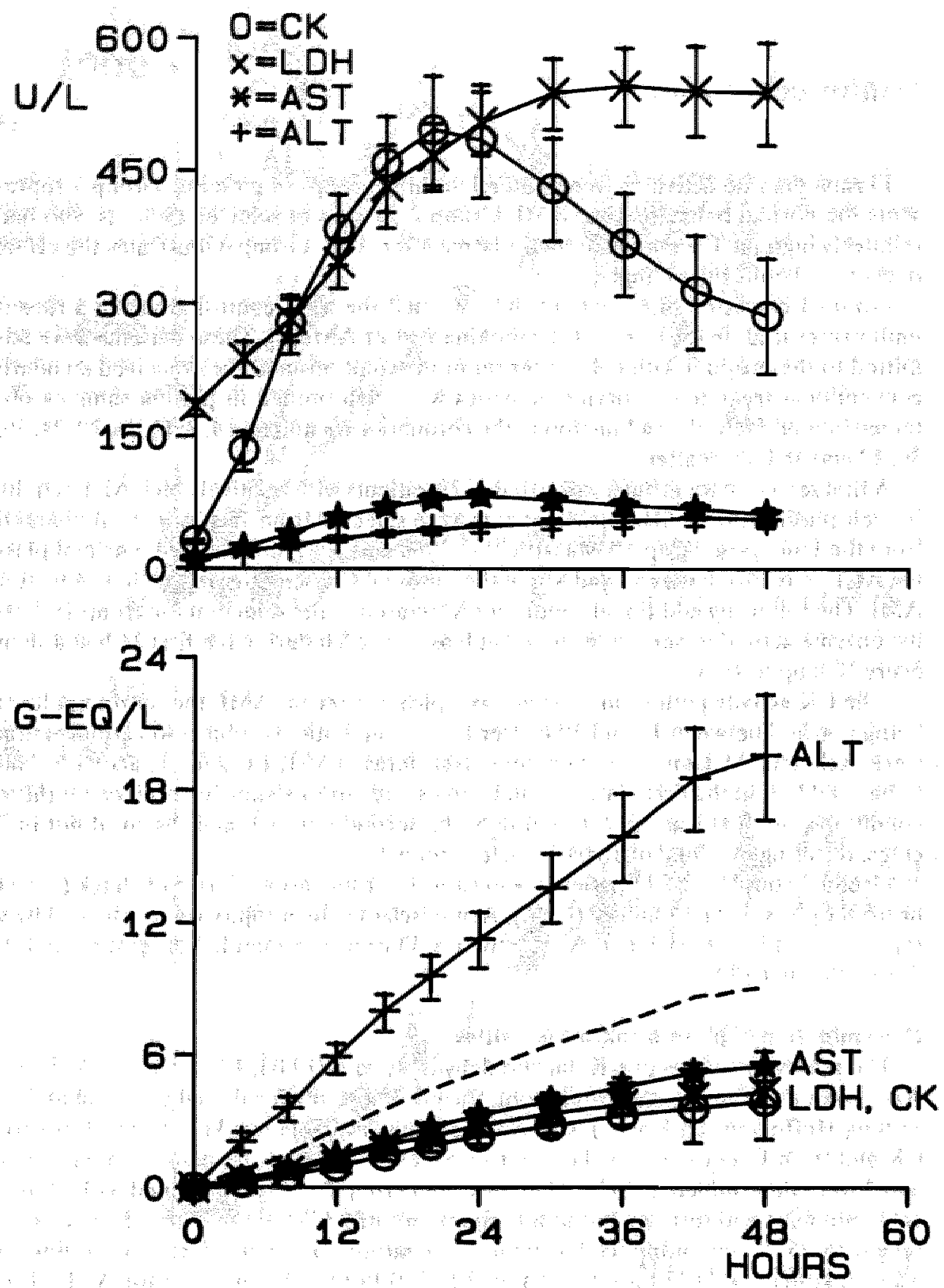

Figure 2. Plasma enzyme activities (upper figure) and cumulative release of enzymes, expressed in gramequivalents of heart tissue per liter of plasma (lower figure), in group 2 . The dotted line is explained in the text. SEM is indicated. 
steady state activities were considered to be those measured in the first sample unless these activities were already above normal: $>60,200,20$ and $20 \mathrm{U} / \mathrm{L}$ respectively for CK, LDH, ALT and AST.

In that case, we used the following standard values: $\mathrm{CK}, 40 \mathrm{U} / \mathrm{L}, \mathrm{LDH}, 125 \mathrm{U} / \mathrm{L}$; AST,10 U/L; and ALT, $10 \mathrm{U} / \mathrm{L}$.

\section{Determination of tissue enzyme content}

Enzyme measurements were made on hearts from patients who died after acute myocardial infarction, the sample being prepared as follows:

A transverse slice of myocardium, $1 \mathrm{~cm}$ in thickness, was cut from the heart midway between apex and base. The slice was divided circumferentially into several samples which were divided again into endo- and epicardial parts (cf. ref 7 for detalls). The 14 resulting pieces were separately homogenized and sonicated in $20 \mathrm{~mL}$ TrisHCl buffer $\left(50 \mathrm{mmol} / \mathrm{L} ; \mathrm{pH} 8.5,0^{\circ} \mathrm{C}\right.$ ), containing $50 \mathrm{mmol}$ of $\mathrm{NaCl}, 15 \mu \mathrm{mol}$ of pyridoxal-5-phosphate, and $3 \mathrm{mmol}$ mercaptoethanol per liter. The suspension was centrifuged and the enzyme activities in the supernatant fluid were determined at $25^{\circ} \mathrm{C}$ as described. In order to avoid infarcted areas, the values presented below in Table 1 are mean activities in three samples with the highest CK activities.

\section{Calculation of cumulative release of enzymes}

The time activity curves measured in plasma were analyzed with the two-compartment model discussed before $[4,5]$. The plasma activity $\mathrm{C}(\mathrm{t})$ at time $t(\mathrm{U} / \mathrm{L})$ is changed by catabolism with a fractional catabolic rate constant, FCR, and by input of enzyme released from heart-muscle cells. In addition, there is transport of enzyme to the extravascular pool with a fractional transcapillary escape rate constant, TER, and extravascular return of enzyme to plasma with a fractional extravascular return rate constant, ERR. Cumulative release of enzyme per liter of plasma from zero time until time $t$ is given by the expression:

$$
Q(t)=C(t)+\text { TER.exp(-ERR.t) } \int_{0}^{t} \exp (E R R . t) C(t) d t+F C R \int_{0}^{t} C(t) d t
$$

The first two terms give the quantities of enzyme released that are still present in plasma and in the extravascular pool. The last term gives the quantity of enzyme catabolized up to time $t$. Values of $\mathrm{C}(t)$ are obtained by subtracting the normal steadystate plasma enzyme activity from the plasma enzyme activity actually measured at time $t$. Fixed values of FCRCK $=0.20 \mathrm{~h}^{-1}$, FCRLDH $=0.015 \mathrm{~h}^{-1}$, FCRAST $=0.088 \mathrm{~h}^{-1}$, FCRALT $=0.034 \mathrm{~h}^{-1}$, TER $=0.014 \mathrm{~h}^{-1}$, and ERR $=0.018 \mathrm{~h}^{-1}$ were used in these calculations $[4,5,8]$.

\section{Myocardial injury expressed in gram-equivalent of tissue}

Cumulative release of enzymes was expressed in gram-equivalents of healthy myocardium per liter of plasma ( $\mathrm{g}-\mathrm{e} / \mathrm{L}$ ). To this end, the calculated values of $\mathrm{Q}(\mathrm{t})$ in $\mathrm{U} / \mathrm{L}$ were divided by the normal enzyme activities per gram of wet weight, i.e., $865 \mathrm{U} / \mathrm{g}$ for CK, $155 \mathrm{U} / \mathrm{g}$ for LDH, $54 \mathrm{U} / \mathrm{g}$ for (cytosolic) AST, and $5 \mathrm{U} / \mathrm{g}$ for ALT $[4,9]$. 
Table 1. Enzyme Activities in Homan Myocardium (U/g wet weight)

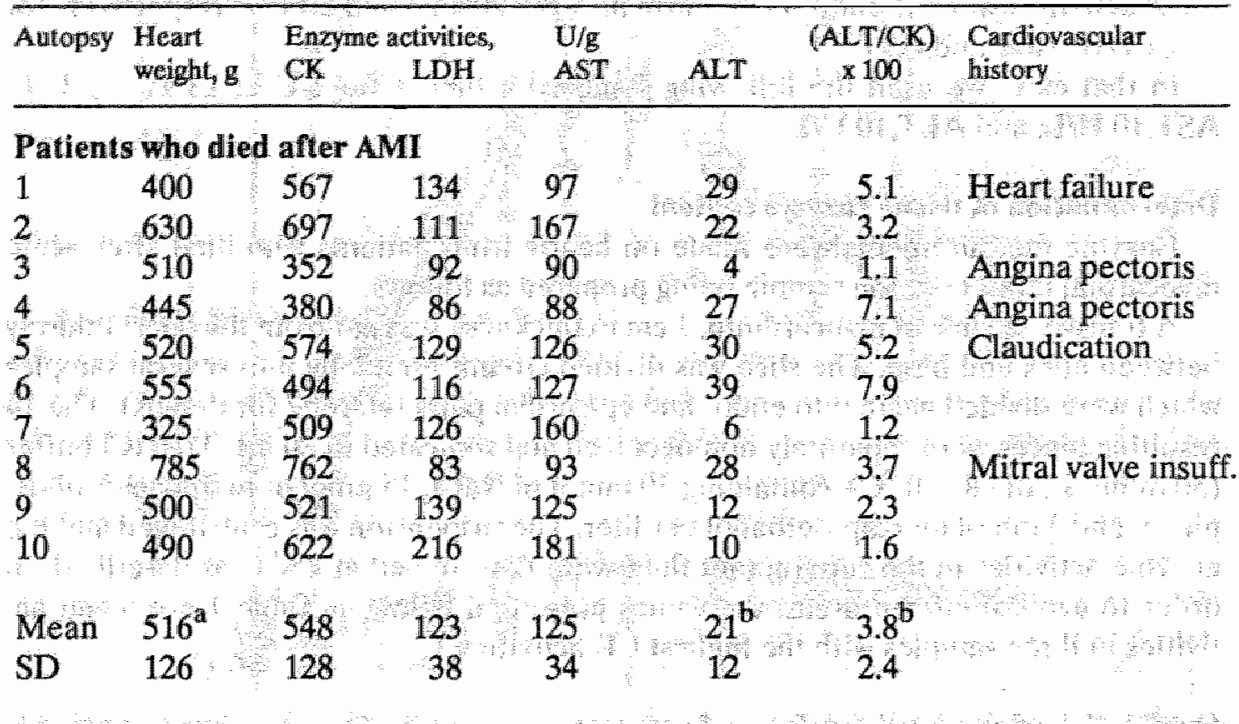

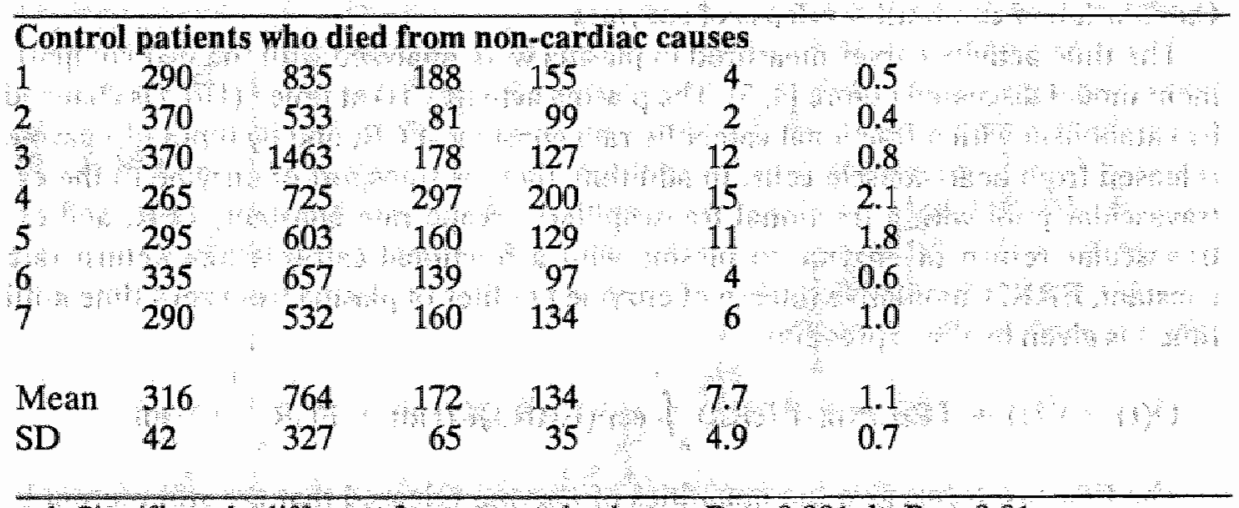

$\mathrm{a}, \mathrm{b}$ Significantly different from control value: $\mathrm{a}, \mathrm{P}<0.001 ; \mathrm{b}, \mathrm{P}<0.01$,

\section{Statistics}

The significance of differences in mean values was calculated by use of student's ttest.

\section{RESULTS}

Figure 1 presents data on the enzyme activities (U/L) in plasma and the cumulative release (g-eq/L) in control patients with AMI (group 1). Identical estimates of the ex- 
tent of injury are obtained from data on the four enzymes CK, LDH, AST, and ALT. As shown in the upper panel of Figure 1, increases in ALT activity in plasma are minimal, and in fact remain usually below the upper limit of the normal reference interval.

Figure 2 shows the results obtained for group 2. It is not surprising to find a high release of ALT in these patients, because this criterion was used in their selection. Note, however, that the release of AST fits the results for $\mathrm{LDH}$ and CK.

Figure 3 shows the parallel release of AST and ALT observed in patients with acute ischemic liver injury. The released activities of AST and ALT have a ratio of AST/ALT $=2.2$ in these patients. If the extra ALT released shown in Figure 2 had been of hepatic origin, the extra AST release would have resulted in a total AST release depicted by the dotted line in the lower panel of Figure 2 and thus would have been significantly higher than was actually observed. Accordingly, the high ALT release in group 2 probably was not caused by liver injury. Moreover, the time course of this ALT release (Fïgure 2, lower panel) coincides with the release pattern of the other cardiac enzymes. Both factors together suggest a high myocardial release of ALT in these patients.

Table 1 presents the result of enzyme determinations in myocardium. The autopsies were performed within $24 \mathrm{~h}$ after death, the mean delay being $6 \mathrm{~h}$. There is little autolytic loss of enzyme activities in this interval $[7,9]$. A significant $(P<0.01)$ increase in the ALT content of pathological hearts is apparent. Under the same assay conditions the mean ALT content in liver is about $20 \mathrm{U} / \mathrm{g}$, i.e. a similar value as found in some of these hearts. The figures for heart weight in Table 1 demonstrate a significant ( $P$ $<0.001$ hypertrophy in the AMI group. There is a tendency to lower CK and LDH activities associated with hypertrophy, although the effect in Table 1 is not significant at the $P=0.05$ level owing to the large variability in the control hearts.

Table 2 presents the cumulative release of enzymes $(\mathrm{Q}(48))$ for group 2. None of the patients shown in this table died in hospital. The average release of ALT in these selected patients is $3.5 \%$ of the release of $\mathrm{CK}$. This is close to the value of $3.8 \%$ in Table 1 for myocardial ALT activity in the AMI group, expressed as a percentage of the CK activity. Both figures indicate that the ALT activity in these hearts are about threefold that in control hearts. As follows from Tables 1 and 2 , only about $40 \%$ of these patients had previous cardiovascular symptoms.

\section{DISCUSSION}

We show here that a high proportion of patients who die after AMI have abnormally high values for myocardial ALT activity, on the average threefold normal. In addition to this proportion of patients who die after AMI, about $4 \%$ (29 out of 750 patients), who survive, show a disproportionately high release of ALT in plasma. Some of these patients already had high values for ALT in plasma before myocardial enzyme release actually started, probably ascribable to pre-existing liver damage. In most of them, however, the release pattern and the absence of extra AST release indicate that this extra ALT is of myocardial rather than hepatic origin. In-hospital mortality after 


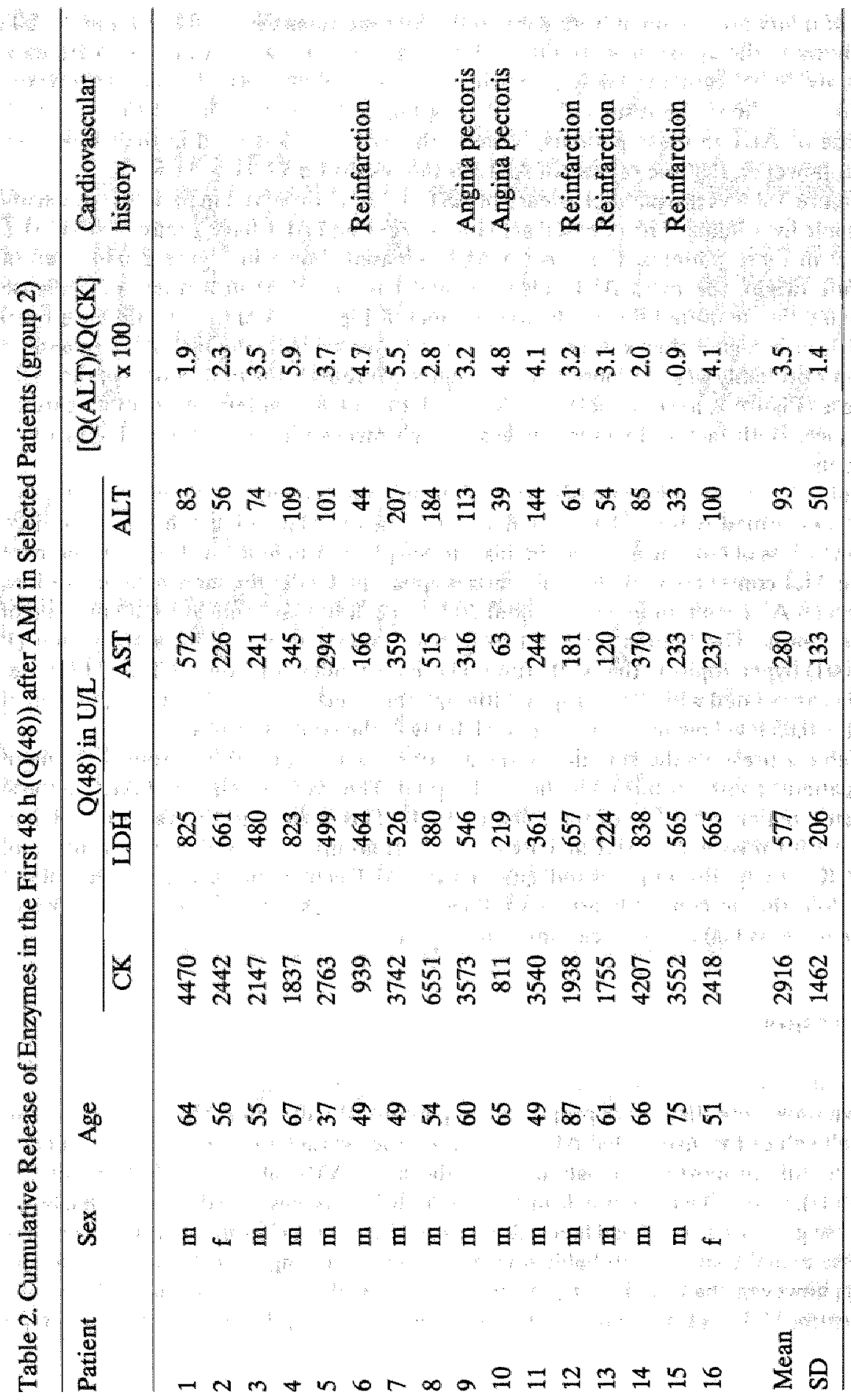


AMI is about $6 \%$, and about half of these patients have high myocardial ALT activities (cf. Table 1), so it is concluded that in about $7 \%$ of patients who suffer from AMI some earlier adaptive or degenerative process has resulted in increased myocardial ALT activities.

In spite of this, it is not surprising to find that the mean release of ALT in the control group 1 conforms to the normal low ALT activity. Patients who died within $48 \mathrm{~h}$ and patients with cardiogenic shock or ventricular fibrillation were excluded [2].

Further, the proportion of about $3 \%$ of patients in group 1 we found to have increased ALT activities in plasma is too small to cause a significant increase in the curve illustrating mean ALT release (cf. Figure 1).

The hearts obtained from patients who died after AMI were hypertrophic (cf. Table 1). They also show low CK activities, which has been related to various forms of cardiomyopathy $[10,11]$. Apparently, most hearts already were showing pathological changes before the fatal infarction occurred.

Table 1 shows that only half of the patients who died after AMI had a clinical history of cardiovascular complaints. A similar situation is shown in Table 2, where only $40 \%$ of patients had previous symptoms. This is surprising because most of the patients presented in this table probably had pathological hearts, as evidenced by their high myocardial ALT release. However, in some large studies on patients who died after acute myocardial infarction $[12,13]$, a low value of $20 \%$ is quoted for the proportion of patients with a history of cardiovascular complaints. This finding suggests that measurements of ALT release in the acute phase of myocardial infarction could be of prognostic value.

As for infarction size, the mean value of $2916 \mathrm{U} / \mathrm{L}$ for CK activity in the patients shown in Table 2 corresponds to $2916 / 865=3.4 \mathrm{~g}$-eq/ $/ \mathrm{L}$ and is much smaller than the mean of $6.8 \mathrm{~g}-\mathrm{eq} / \mathrm{L}$ in the control group 1 (cf. Figure 1). This could explain why these patients with already-compromised hearts survive.

Little is known about the influence of hypoxia on myocardial amino acid metabolism, but increased ALT activities in hypoxic hearts could be related to the observation that, in the rat, myocardial alanine increases rapidly after $20 \mathrm{~min}$ of acute hypoxia [14 15]. This confirms more detailed knowledge of the effects of hypoxia on skeletal muscle. It has been shown in healthy volunteers that prolonged, intensive exercise results in the activation of the branched-chain alpha-keto acid dehydrogenase complex [16]. This enzyme is rate-limiting in the degradation of the branched-chain amino acids leucine, isoleucine and valine and is in a phosphorylated inactive state in the resting muscle. Branched-chain amino acids may thus serve as alternative substrates in the glycogen-depleted muscle. Ultimately, the amino groups are transferred to alanine and glutamine, both of which are released into the circulation in large quantities $[17,18]$. Accelerated amino acid metabolism could thus be an alternative for the hypoxic heart, and the induction of ALT could reflect this chronic adapted state. 

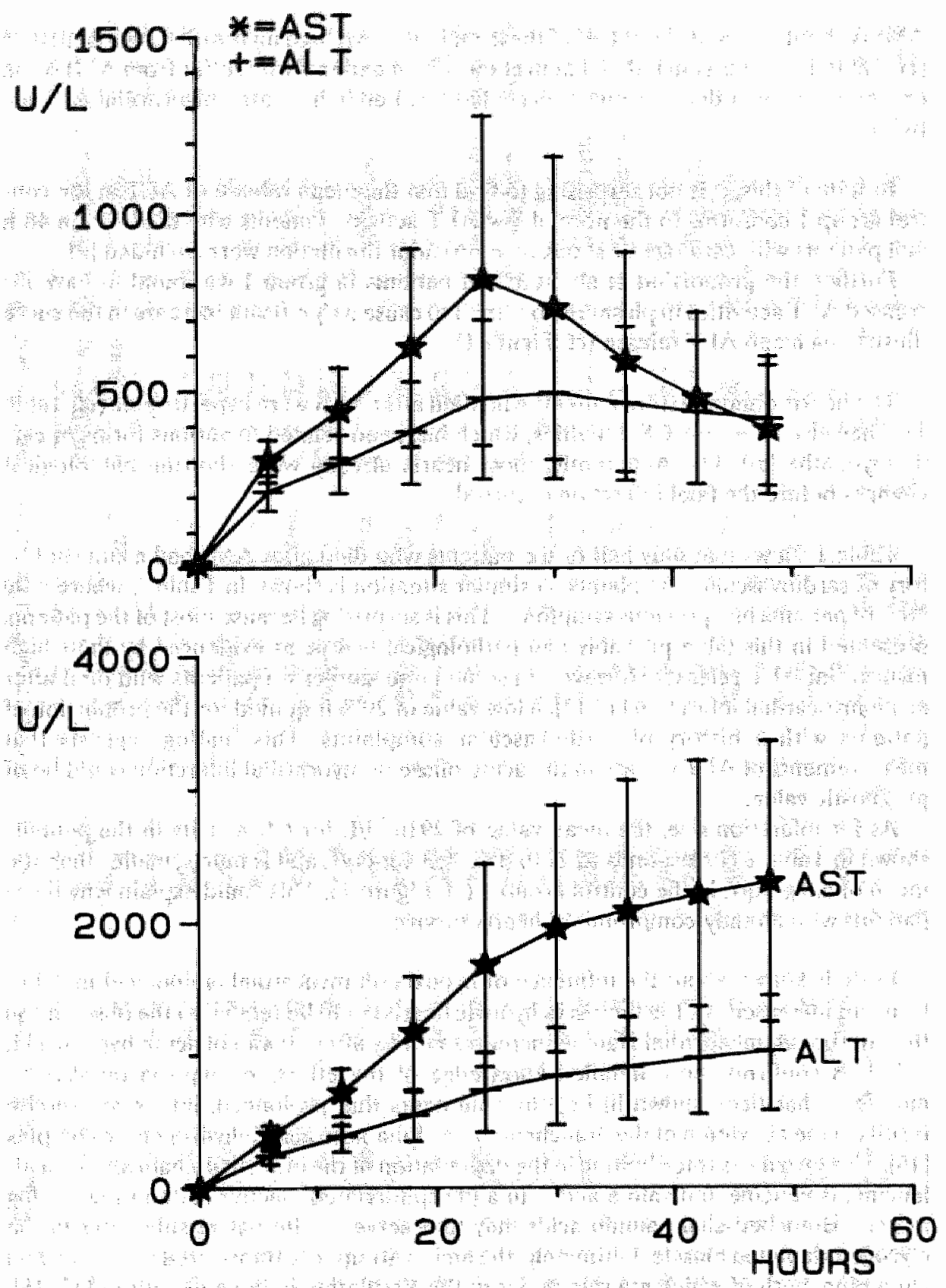

Figure 3. Plasma enzyme activities (upper figures) and cumulative release of enzymes (lower figure) in group 3. SEM is indicated. 


\section{ACKNOWLEDGEMENT:}

Our fruitful discussions with Dr. A.J.M. Wagenmakers are gratefully acknowledged.

\section{REFERENCES}

1. Van der Laarse A, Vermeer F, Hermens WT, Willems GM, De Neef K, Simoons ML, et al. Effects of early intracoronary streptokinase on infarct size estimated from cumulative enzyme release and enzyme release rate. A randomized trial of 533 patients with acute myocardial infarction. Am Heart J 1986;112:672-81.

2. De Zwaan C, Willems GM, Vermeer F, Res J, Verheugt FWA, Van der Laarse A, et al. Enzyme tests in the evaluation of thrombolysis in acute myocardial infarction. Br Heart J 1988;59:175-83.

3. Simoons ML, Betriu A, Col J, Von Essen R, Lubsen J, Michel PL, et al. Thrombolysis with tissue plasminogen activator in acute myocardial infarction: No additional benefit from immediate percutaneous coronary angioplasty. Lancet 1988;i:197-203.

4. Willems GM, Van der Veen FH, Huysmans HA, Flameng W, De Meyere R, Van der Laarse A, et al. Enzymatic assessment of myocardial necrosis after cardiac surgery. Differentiation from skeletal muscle damage, hemolysis and liver injury. Am Heart J 1985;109:1243-52.

5. Willems GM, Visser MP, Krill MTA, Hermens WTh. Quantitative analysis of plasma enzyme levels based on simultaneous determination of different enzymes. Cardiovasc Res 1982;16:120-31.

6. Oostenbroek RJ, Willems GM, Boumans MLL, Soeters PB, Hermens WTh. Liver damage as a potential source of error in the estimation of myocardial infarct size from plasma creatine kinase activity. Cardiovasc Res 1985;19:113-9.

7. Van der Veen FH, Visser R, Willems GM, Kop-Klaassen B, Hermens WTh. Myocardial enzyme depletion in infarcted human hearts: infarct size and equivalent tissue mass. Cardiovasc Res 1988;22:611-9.

8. Hermens WTh, Willems GM, Visser MP. Quantification of circulating proteins. Boston: Martinus Nijhoff, 1982:96-107.

9. Van der Laarse A, Dijkshoorn NJ, Hollaar L, Caspers Th. The (iso)enzyme activities of lactate dehydrogenase, alpha-hydroxybutyrate dehydrogenase, creatine kinase and aspartate aminotransferase in human myocardial biopsies and autopsies. Clin Chim Acta 1980;104:381-91.

10. Ingwall JS, Kramer MF, Fifer MA et al., The creatine kinase system in normal and diseased human myocardium. N Eng J Med 1985;313:1050-4. 
11. Van der Laarse A, Hollaar L, Bogers AJJC, Huysmans HA, De Haan HPJ, Buis B. A comparative study on enzymatic data from myocardial biopsies and cardiac function in patients who underwent cardiac surgery. Thorac Cardiovasc Surgeon 1984;32:277-82.

12. Simoons ML, Serruys PW, Van de Brand W. Early thrombolysis in acute myocardial infarction, limitation of infarct size and improved survival. J Am Coll Card 1986;7:717-28.

13. Gissi. Effectiveness of intravenous thrombolytic treatment in acute myocardial infarction. Lancet 1986;:397-402.

14. Freminet A. Carbohydrate and amino acid metabolism during acute hypoxia in rats: blood and heart metabolites. Comp Biochem Physiol 1981;70B:427-33.

15. Taegtmeyer H, Roberts AFC, Raine AEG. Energy metabolism in reperfused heart muscle: metabolic correlates to return of function. J Am Coll Cardiol 1985;6:86470.

16. Wagenmakers AJM, Brookes JH, Coakley JH, Reilly T, Edwards RHT. The activity of the branched-chain 2-oxo acid dehydrogenase in human muscle before and after exercise, Clin Sci 1987;73:53P.

17. Chang TW, Goldberg AL. The origin of alanine produced in skeletal muscle. J Biol Chem 1978;253:3677-84.

18. Chang TW, Goldberg AL. The metabolic fates of amino acids and the formation of glutamine in skeletal muscle. J Biol Chem 1978;253:3685-95. 


\section{CHAPTER 8}

\section{SUMMARY AND CONCLUSIONS}

Over the last thirty years the plasma activities of liver enzymes, e.g. alanine aminotransferase (ALT), aspartate aminotransferase (AST) and lactate dehydrogenase (LDH), alkaline phosphatase (AP), gamma-glutamyltransferase (GGT), ornithine carbamyltransferase (OCT) and glutamate dehydrogenase (GLDH) have been used extensively in clinical diagnosis of liver disease. In contrast to the situation for the heart, release of enzymes from the liver has seldom been used to assess the extent of organ damage. In the heart, necrotic tissue is not replaced by muscle cells and cumulative enzyme release thus reflects irreversible loss of functional tissue. The liver, however, has a large regenerative capacity and estimation of hepatic necrosis will not be directly related to residual liver function.

In spite of this limitation, however, the liver is much more interesting than the heart from the point of view of clinical enzymology. Different types of hepatic injury have been related to different patterns of enzyme release. For instance, the solubilization of membrane enzymes, as observed during cholestasis, is thought to reflect the detergent action of accumulated bile acids and an extensive induction of enzymes in hepatocytes that remain relatively healthy and well-perfused. Massive release of cytosolic liver enzymes with limited or delayed release of mitochondrial enzymes may indicate primary injury to the plasma membrane in various forms of toxic liver damage whereas, in contrast, simultaneous release of enzymes from different organelles is observed in acute liver necrosis due to shock or right-side heart failure. Due to induction or inhibition of the synthesis of different enzymes, hepatic enzyme content may be profoundly changed in various forms of liver disease and it would be of major diagnostic value if such changes could be detected from altered ratios of released enzymes in plasma. Data on the intracellular turnover rates of different enzymes can be related to the daily loss of these enzymes in plasma during chronic liver disease. This may allow conclusions about the contribution of cellular disruption versus leakage of enzymes from viable cells as the main mechanisms of enzyme release, and also about the remaining regenerative capacity of the liver.

It has long been realized, however, that these aspects cannot be studied quantitatively by simple measurement of plasma enzyme activities. Due to enzyme-dependent elimination rates from plasma, and also due to exchange of enzymes between vascular and extravascular enzyme pools, the enzyme activities in plasma present a distorted picture of the total released activities. Moreover, the degree of distortion is dependent on the time course of release and will be larger in a long-lasting chronic type of release 
than after a short burst of massive enzyme leakage. The main goal of the present thesis is to overcome this limitation and to develop methods by which the total "cumulative" release of enzymes in plasma can be calculated, taking account of intravascular catabolism $_{i}$ extravasation and extravascular return of enzymes.

In Chapter 1 the pitfalls are discussed, that may be encountered if in the determination and interpretation of cumulative enzyme release. Also the methods, by which the activity of the enzymes is assayed, are described. For most enzymes there are standard spectrophotometrical procedures, using commercially available test kits. For the determination of OCT activity, however, a new method has been developed (Chapter 2), that circumvents urease and deproteinization steps, and is based on enzymatic determination of ammonia.

Estimation of cumulative release necessitates the parameter values of the Fractional Catabolic Rate constants (FCR) of the liver enzymes under study. The method, by which these parameters can be estimated, is explained in Chapter 3 , and is applied to the time-activity curves of selected patients with acute massive release of cytosolic liver enzymes. It is shown that the apparent disappearance rates of enzyme activities from plasma, reported in several studies in the literature, underestimate the true values of FCR by factors of about 1.5 to 3 . Using the values of FCR(AST), FCR(ALT), and FCR(LDH) thus obtained, it is demonstrated that these enzymes are released in plasma in proportion to their presence in liver tissue and this finding indicates that altered hepatic enzyme activities may indeed be detected by altered ratios of cumulative release in plasma. It is also shown that the mean extent of injury in this selected group of patients is considerable and corresponds to more than 400 gram- equivalents of liver tissue.

A slightly different method was used in Chapter 4 to estimate the values of FCR for three mitochondrial enzymes, mAST, OCT, and GLDH. Because the time-activity curves of patients with liver disease were selected on the presence of the initial upstroke (necessary to estimate the proportion of released activities - cf. Chapter 3 ), this has also produced unusually complete curves of mitochondrial enzyme release. The mAST activities measured in acute liver necrosis appear to be much higher than previously published, probably because the activities were measured so early in the event and because mAST is rapidly catabolized. A remarkable synchronism of both cytosolic and mitochondrial enzyme release has been observed, questioning the validity of the reperfusion model for temporary ischemia in vivo, which claims a delay in the release of the mitochondrial enzyme fraction. Probably, the reperfusion injury in these models results in an unpliysiological, selective destruction of the plasma membrane (Chapter 4).

As for the relevance of enzymes as a biomarker for liver cell necrosis, OCT and mAST release appears to be more complete than release of GLDH, possibly related to a circulating inhibitor that has been demonstrated for the latter enzyme in Reye's syndrome. If methodological problems have been solved (Chapter 2), OCT appears to be a suitable, liver-specific biomarker (Chapter 4). In alcohol abuse the value of mAST as a biomarker has already been advocated.

The values of FCR(AP) and FCR(GGT) are estimated in patients with acute cholestasis (Chapter 5). This estimation is based on the very slow rate of elimination of 
both enzymes which allows determination of the apparent disappearance rates more than 100 hours after the acute event, when it can be assumed that no residual release occurs.

The release of membrane-bound enzymes does not indicate incipient liver cell necrosis. On the contrary, there appears to be an inverse relation between the release of membrane-bound enzymes and cytosolic enzyme release. It seems as if prolonged exposure to bile acids first produces induction and solubilization of membrane-bound enzymes and eventually results in liver cell necrosis from chronic detergent injury.

A decreased content of LDH in patients with 'acute' cholestatic liver injury has been demonstrated by comparison of ratios of released cumulative activities and confirms data obtained from biopsies in the literature. As the intracellular turnover of LDH is quite slow ( $>16$ days), this finding suggests that the liver has been exposed to the effect of bile acids long before the patient experiences any complaint:

A decreased content of ALT as evidenced by altered ratios of released cumulative activities has been demonstrated in alcoholic liver injury, completely in agreement with previous investigations on liver enzyme content in various forms of alcohollic liver disease. The well-known elevated AST/ALT ratio in alcoholic liver injury mirrors this ALT decrease, but does not represent the true magnitude of this effect. It is shown, for instance, that the AST/ALT ratio of plasma activities decreases when the patients pass from an acute to a chronic phase, whereas the ratio of cumulative release of both enzymes remains unaltered.

A daily cumulative enzyme release equivalent to 8 grams of liver tissue per day has been calculated in ambulatory patients with alcohol abuse. The slow intracellular turnover rate of LDH makes it improbable that this enzyme could leak from viable cells at this rate and suggests that replenishment of enzyme is effected by regeneration of liver cells.

In Chapter 7 it is discussed why some patients with acute myocardial infarction show an unexpectedly high release of ALT. Increased plasma ALT activity in patients with myocardial infarction has always been ascribed to some degree of central venous congestion with subsequent centrolobular liver necrosis. However, the expected extra AST release could not be demonstrated in these patients. Further, the time course of release of ALT does not conform to the liver, but to the heart: It is concluded that in a subset of patients with severe myocardial disease not the liver, but the heart becomes a source of ALT release and this finding is confirmed by determination of enzyme activities in hearts obtained from patients who died from myocardial infarction.

The results of the last chapter demonstrate that complex enzyme patterns in plasma can be analyzed succesfully by means of quantitation of enzyme release. This implies, for instance, that after liver transplantation the injury to the transplanted organ can probably be differentiated from surgical trauma and the effects of anaesthesia. This seems a promising field of future application of the methods developed in this thesis. In general, calculation of cumulative enzyme release will provide accurate, quantitative data on liver injury. These data will contribute to a better understanding of the natural course of liver disease and the effect of therapeutical interventions. 


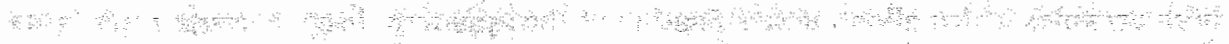
a 1 a

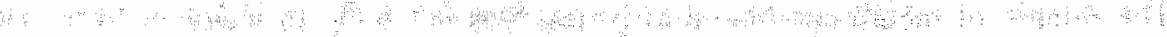

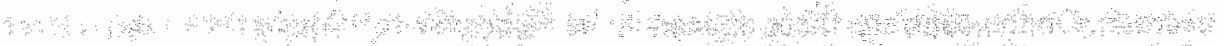

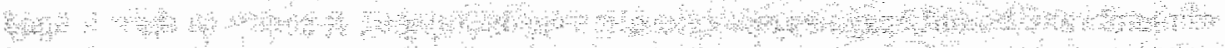

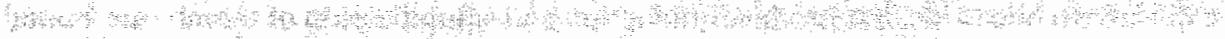
a ${ }^{2}$. १ै।

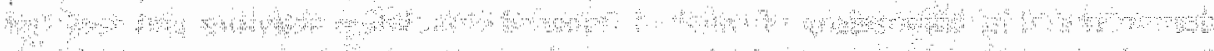

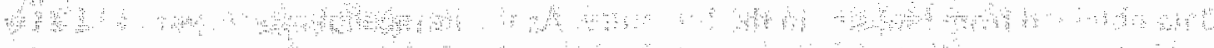
स्य अ,

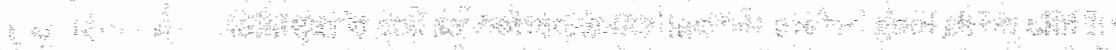
मिक्ष

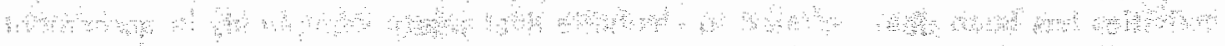
: $\begin{aligned} & \text { a } \\ & \text { क }\end{aligned}$

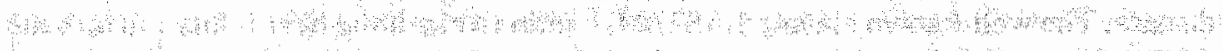

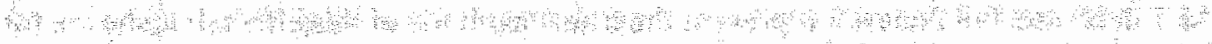

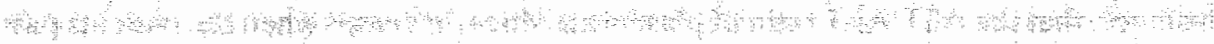

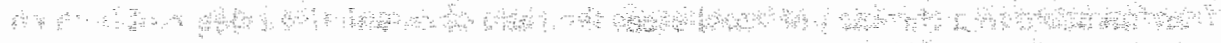

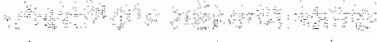
A A

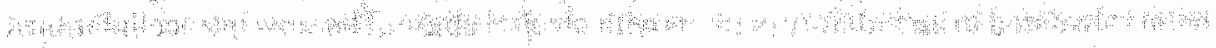
Aमै

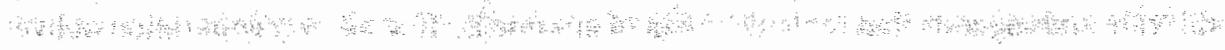

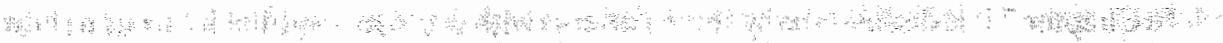

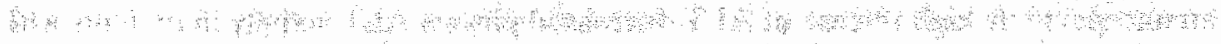

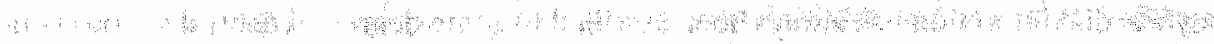

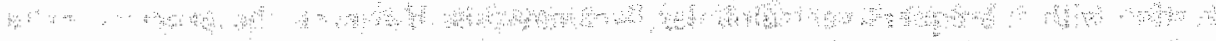

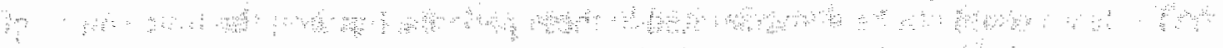

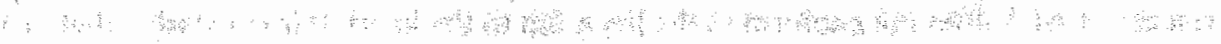

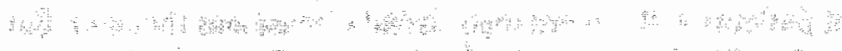

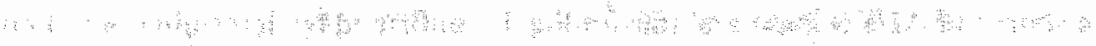

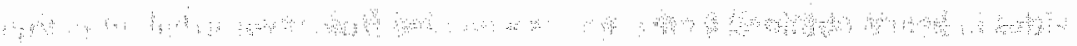

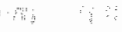

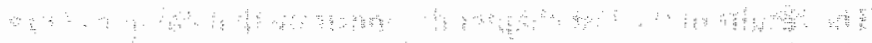

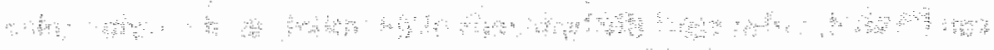

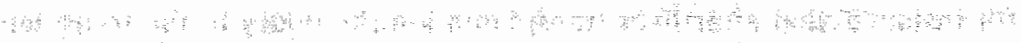
$\because$ :

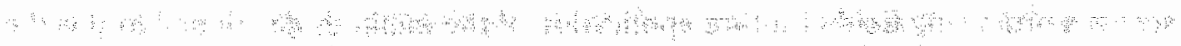

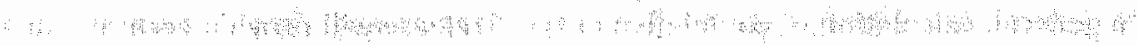

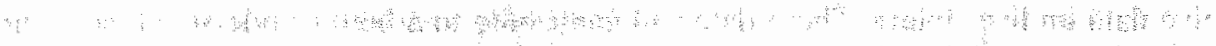

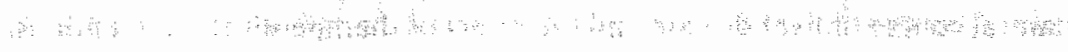




\section{SAMENVATTING}

De laatste dertig jaar zijn de plasmabepalingen van leverenzymen, zoals alanine aminotransferase (ALT), aspartaat aminotranferase (AST), lactaat dehydrogenase (LDH), alkalische fosfatase (AP), gamma-glutamyl transferase (GGT), ornithine carbamyl transferase (OCT) en glutamaat dehydrogenase (GLDH) toenemend gebruikt voor de diagnostiek van leveraandoeningen. In tegenstelling tot de situatie bij het hart, zijn de enzymuitstortingen uit de lever zelden gebruikt om de omvang van orgaanbeschadiging vast te stellen. Necrotisch weefsel wordt in het myocard niet vervangen door nieuwe hartspiercellen en daarom weerspiegelt enzymverlies in het myocard het directe verlies van functioneel weefsel. De lever daarentegen heeft een grote regeneratieve capaciteit en schatting van enzymuitstorting uit de lever kan om die reden niet direct aan de restfunctie van dat orgaan gerelateerd worden. Ondanks deze beperking echter, is de lever vanuit het standpunt van de klinisch enzymoloog veel interessanter dan het hart. Verschillende vormen van leverbeschadiging leiden tot andere enzympatronen in het plasma. Zo zal bij een afsluiting van de afvoerende galwegen een ophoping van galzouten optreden en deze kunnen een detergerende werking uitoefenen op membranen en membraangebonden enzymen kunnen daardoor vrijkomen. De levercellen reageren daarop met inductie van membraangebonden enzymen zonder kennelijk verder veel schade te ondervinden.

Een flinke uitstorting van cytoplasmatische leverenzymen met beperkte of vertraagde uitstorting van mitochondriale enzymen lijkt te duiden op een primaire beschadiging van de levercelmembraan in verschillende vormen van toxische levercelbeschadiging, terwijl daarentegen het gelijktijdig vrijkomen van enzymen uit verschillende celorganellen veeleer waargenomen wordt bij acute necrose na shock of rechtsdecompensatie.

Ten gevolge van inductie of inhibitie van synthese van verschillende enzymen, kan bij verschillende ziekten de enzyminhoud van leverweefsel ingrijpend gewijzigd worden en het zou van grote diagnostische waarde zijn als dergelijke veranderingen opgespoord kunnen worden uit veranderingen in de verhouding van uitgestorte enzymen in plasma. Gegevens over intracellulaire turnover van verschillende enzymen kunnen gerelateerd worden aan het dagelijks verlies van enzymen in plasma tijdens chronische leveraandoeningen. Hieruit kunnen weer belangrijke conclusies getrokken worden over de bijdrage van betzij integraal celverval, hetzij het lekken van enzymen uit levende cellen als het belangrijkste mechanisme van enzymuitstorting, en over de regeneratiecapaciteit van de lever. 
Eenvoudige meting van plasma enzymactiviteit is niet voldoende om dergelijke vraagstellingen te beantwoorden. Een verwrongen beeld van de totale uitgestorte enzymactiviteit is het resultaat als geen rekening gehouden wordt met enzymspecifieke eliminatieconstanten uit plasma en de uitwisseling van enzymen tussen vasculaire en extravasculaire compartimenten. Bovendien kan het tijdswerloop van de uitstorting het enzymbeeld in plasma beinvloeden: bij een langdurige chronische uitstorting zal dit effect anders zijn dan bij een acuut, kortdurend vrijkomen van enzymen.

Het belangrijkste doel van dit proefschrift is om dit soort beperkingen te overwinnen en methoden te ontwikkelen die het mogelijk maken de cumulatieve uitstorting van enzymen in plasma te bepalen, rekening houdend met intravasculaire afbraak, extravasatie en nalevering van enzymen uit het extravasculaire compartiment.

In Hoofdstuk 1 worden de problemen besproken die optreden als men de enzymuitstorting uit de lever wil kwantificeren en interpreteren. De methoden, waarmee de enzymactiviteiten worden bepaald worden hier eveneens beschreven. Voor de meeste enzymen zijn het standaard spectrofotometrische bepalingen, gewoonlijk verricht met commercieel verkrijgbare testkits. Ten behoeve van de bepaling van de OCT activiteit is een nieuwe methode ontwikkeld (Hoofdstuk 2), die onwenselijke ammoniakvorming uit eiwitten en ureum omzeilt.

Zoals besproken moet men de FCR constanten keninen vooraleer de cumulatieve uitstorting van de leverenzymen uitgerekend kan worden. Een methode, waarmee deze parameters gesehat kunnen worden, wordt uiteengezet in Hoofdstuk 3 , en deze wordt toegepast op de tijd-activiteit curves van tien nauwkeurig geselecteerde patiënten met acute enzymuitstorting. Het blijkt, dat de schijnbare verdwijningsconstanten van enzymactiviteiten uit plasma, in de literatuur gemeld, in het algemeen de werkelijke FCR waarden met een factor 1,5 a 3 onderschatten.

Met behulp van de aldus verkregen waarden van FCR(AST), FCR(ALT) en FCR(LDH) wordt vervolgens de cumulatieve uitstorting in plasma uitgerekend en deze uitstorting blijkt volledig in verhouding tot de activiteit van de betreffende enzymen in leverweefsel te geschieden. Dit geeft aan dat veranderde enzymactiviteiten in leverweefsel waarschijnlijk opgespoord kunnen worden met behulp van de veranderde ratio's van cumulatieve enzymuitstorting in plasma. Voorts blijkt de gemiddelde omvang van leverschade in deze groep patiënten aanzienlijk te zijn en overeen te komen met meer dan 400 gramequivalenten leverweefsel.

Een lets andere methode om de FCR waarden te schatten werd gebruikt in Hoofdstuk 4 voor drie mitochondriale enzymen, mAST, OCT en GLDH. Omdat bij de selectie van patiënten de aanwezigheid van een initiele stijging van de enzymactiviteit als criterium gebruikt is (noodzakelijk om de verhouding van vrijgekomen activiteiten te schatten - vgl. Hoofdstuk 3), heeft dit en passant ongewoon complete curves van mitochondrial enzymuitstorting opgeleverd. De mAST activiteit gemeten in acute levernecrose blijkt veel hoger te zijn dan tevoren gepubliceerd, waarschijnlijk enerzijds doordat zo vroeg gemeten werd en anderzijds doordat mAST zeer snel wordt afgebroken. Een opmerkelijke synchroniciteit van cytoplasmatische en mitochondriale enzymuitstorting werd waargenomen, die vraagtekens plaatst bij de validiteit van het reperfusiemodel voor tijdelijke ischemie in vivo. Daarbij wordt namelijk juist een vertraging 
gevonden in het vrijkomen wan de mitochondriale enzymfractie. Waarschijnlijk resulteert reperfusieschade in deze modellen in selectieve beschadiging wan de plasmamembraan (Hoofdstuk 4).

Wat betreft het belang wan enzymen als indices van levercelnecrose, moet hier de omgewoon complete uitstorting van OCT en mAST genoemd worden, in tegenstelling tot GLDH. Deze waarneming onderstreept nog eens het nut van OCT als leverspecifiek enzym (Hoofdstuk 4), te meer waar methodologische problemen nu zijn opgelost (Hoofdstuk 2).

De waarden van FCR(GGT) en FCR(AP) zijn geschat in patiënten met acute galwegafsluiting (Hoofdstuk 5). De schatting is gebaseerd op de zeer trage eliminatie van deze beide enzymen, waardoor de verdwijning meer dan 100 uur na het actute moment gemeten kan worden, als aangenomen mag worden dat geen uitstorting meer plaatsvindt. In dat geval kan de FCR op eenvoudige wijze afgeleid worden uit de schijnbare verdwijningssnelheid.

De uitstorting van membraangebonden enzymen wijst niet op dreigende levercelnecrose. Integendeel, het lijkt of er een inverse relatie bestaat tussen de uitstorting van membraangebonden en cytoplasmatische enzymen. Langdurige blootstelling aan galzouten lijkt eerst inductie en solubilisatie van membraangebonden enzymen te veroorzaken en uiteindelijk pas te leiden tot celnecrose ten gevolge van chronische detergentieschade.

Een afgenomen LDH inhoud bij patiënten met acute galwegobstructie werd aangetoond door middel van veranderde verhoudingen van cumulatieve uitgestorte leverenzymen. Dit wordt bevestigd door gegevens uit de literatuur, verkregen uit biopten van leverweefsel van patiënten met acute galwegobstructie. Daar de intracellulaire omzetting van $L D H$ nogal langzaam is ( $>16$ dagen), lijkt de lever aanzienlijk langer blootgesteld te zijn aan het effect van galzouten dan men op grond van de klachten van de patiënt zou aannemen.

Een afgenomen ALT inhoud van de lever, eveneens blijkens de veranderde verhoudingen van cumulatieve enzymuitstorting, werd aangetoond in Hoofdstuk 6. Dit is in overeenstemming met literatuurgegevens over enzymactiviteiten in leverblopsieen bij patiënten met verschillende vormen van alcoholische leverbeschadiging. De bekende (verhoogde) AST/ALT ratio bij deze patiënten weerspiegelt deels de ALT afname in de lever, maar toont niet de volle onvang van dit effekt. Zo nam bijvoorbeeld de AST/ALT ratio in plasma af, als de ziekte overging van een acute naar een chronische fase, terwijl de verhouding van cumulatief uitgestorte activiteit vản deze enzymen onveranderd bleef.

Een dagelijkse cumulatieve enzymuittstorting overeenkomend met acht gram leverweefsel werd berekend in poliklinische patiënten met aktief alcoholisch leverlijden. Het is in dit kader moeilijk voor te stellen dlat bijwoorbeeld het aanvullen van LDH, gezien de langzame intracellulaire omzetting van dit enzym, plaatsvindt door verhoogde synthese in nog viabele levercellen. Veel waarschijnlijker lijkt dat aanvulling geschiedt door regeneratie van levercellen.

In Hoofdstuk 7 wordt de ALT verhoging van sommige patiënten met acuut myocardinfarct besproken. Een toegenomen plasma ALT bij deze patiënten wordt klassiek toegeschreven aan de gevolgen van leverstuwing met daardoor enige centro- 
lobulaire levernecrose. De plasma AST verhoging van deze patiènten is dan niet alleen afkomstig uit het myocard, maar ook uit de lever. Echter, extra AST uitstorting kan bij deze patiënten niet aangetoond worden. Voorts past het tijdsverloop van uitstorting van ALT beter bij het myocard dan bij de lever. Hieruit wordt geconcludeerd dat in een deel van de patiënten met een myocardaandoening niet de lever, maar het hart de bron is van de ALT uitstorting en dit wordt bevestigd met enzymbepaling in harten wan patiênten die overlijden na een acuut myocardinfarct.

Het in liet laatste hoofdstuk beschreven resultaat toont aan dat complexe enzympatronen in plasma met sukses geanalyseerd kunnen worden door berekening van de enzymuitstorting. Zo moet het waarschijnlijk mogelijk zijn om bij levertransplantatie de beschadiging van de getransplanteerde lever te onderscheiden van het operatietrauma en de gevolgen van anaesthesie. Dit lijkt een veelbelovend gebied voor toekomstige toepassing van de methoden die in dit proefschrift werden ontwikkeld. In het algemeen zal de berekening van cumulatieve enzymuitstorting nauwkeuriger gegevens kunnen opleveren betreffende de schade toegebracht aan de lever en daardoor beter inzicht geven in het natuurlijk beloop van leveraandoeningen en het effect van therapeutische interventies. 
Want tussen droom en daad

staan wetten in de weg en praktische bezwaren, en ook weemoedigheid, die niemand kan verklaren, en die des avonds komt, wanneer men slapen gaat.

Een proefschrift maak je niet alleen en hier heb ik eindelijk de gelegenheid de velen die zich belangeloos voor het onderzoek hebben ingezet, te bedanken. Hierbij denk ik vooral aan verplegend personeel van vrijwel alle afdelingen interne geneeskunde, algemene heelkunde en intensive care. Bij nacht en ontij hebben zij ervoor gezorgd dat de voor dit onderzoek zo noodzakelijke curves tot stand kwamen. Overdag heeft vooral de prikdienst mij geholpen. Hiervoor mijn hartelijke dank.

Moge voor de patienten het resultaat van dit onderzoek een genoegdoening zijn voor het ongemak.

Ik dank Professor Flendrig voor het vertrouwen dat hij in mij stelde en voor de steun die hij mij tijdens het onderzoek gegeven heeft.

Dr. Hermens, beste Wim, hoe moet ik je bedanken? zonder je creatieve, heldere denken was dit proefschrift er niet gekomen, en dat meen ik.

De analisten die ik op het lab biofysica/heelkunde heb leren kennen, dank ik voor de gezellige tijd die ik bij hun heb doorgebracht. Bernadette, Mieke en Marie-Louise dank ik speciaal voor het vele werk dat ze altijd met plezier voor mij gedlaan hebben. Arnold Vulto, die mij heeft ingewijd in de omgang met PC's: onder jouw leiding ben ik van muurbloem tot macho geworden (met computers) en toch nog mens gebleven. Arnold, voor dit en autre chose dank ik je hartelijk.

De stimulerende gesprekken met Hans Wolters, Hans Fiolet, Karel Leunissen, Bert van de Berg, Liang Kho, Jean-Pierre Sels, Gert van Dijck en Jon Vismans vergeet ik mijn leven lang niet.

De leden van de beoordelingscommissie dank ik voor hun lof en opbouwende kritiek. Mag ik in speciaal Dr. Willems danken voor zijn voortreffelijke kanttekeningen?

I am indebted to Prof. Dr. Schmidt for her kind letters and constructive criticism.

Dr. Guido Heidendal dank ik voor zijn engelengeduld.

De trouwe vriendschap van Rob en Sonja Visser waren een steun voor mij in barre tijden.

Ireentje, jou dank ik op mijn eigen manier.

Maar, vóór eenieder hier genoemd, gaan mijn dankbetuigingen uit naar mijn lieve vader, en gedenk ik mijn lieve moeder, die alles hebben gedaan om dit voor mij mogelijk te maken. 


\section{CURRICULUM VITAE}

Henny Peltenburg werd op 25 januari 1955 te 's-Gravenhage geboren. In 1974 behaalde hij het Atheneum-B diploma an het St. Jans College te 's-Gravenhage. In hetzelfde jaar begon hij de studie Geneeskunde aan de Medische Faculteit Maastricht. Het artsexamen behaalde hij in 1980. De specialisatie Interne Geneeskunde (Hoofd aanvankelijk Dr. J. Coenegracht, sinds 1982 Prof. Dr. J.A. Flendrig) werd aangevangen in 1982. In 1988 liet hij zich registreren als internist en voltooide hij het in dit proefschrift beschreven onderzoek. In 1989 ving hij aan met de opleiding Nucleaire Geneeskunde. 